\title{
SH 463
}

.057 




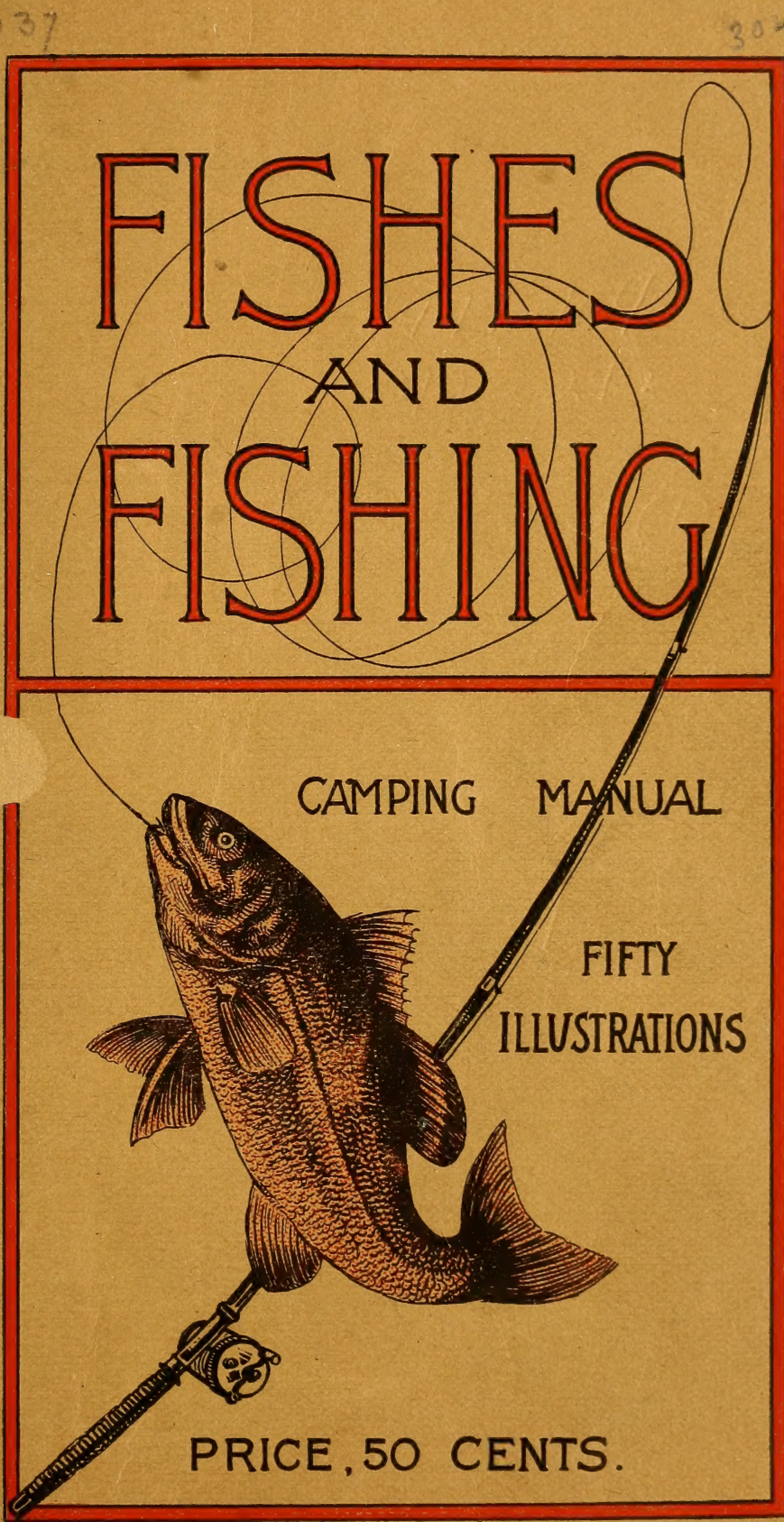




\section{FISHES AND FISHING}

\section{COMPLETE}

\section{FISHING AND CAMPING MANUAL}

FIFTY ILLUSTRATIONS

Description of Fish Found in Western Waters

\section{BAIT AND FLY CASTING \\ Woodcraft}

Game and Fish Laws

Secrets of Catching Fish

Camp Cooking and Camp Making

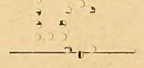

I,000 POINTS WORTH KNOWING

L. E. CAVALIER 

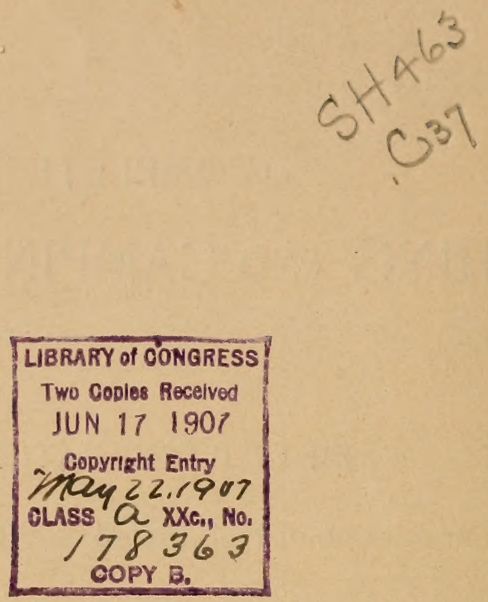

Copyright 1907, by L. E. Cavalier.

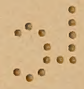




\section{PREFACE.}

This book is published as an aid to anglers and sportsmen those seeking recreation in the woods and on the lakes of Wisconsin and Minnesota, and the west generally, and treats of the fishes and camp life and recreation in a general way, omitting the small details which everyone should know who knows enough to take an outing.

The tendency for summer vacations is growing greater each year as both employer and employe realize the benefits of an annual outing.

While fishing is by no means the sole object of a visit to the woods it furnishes a basis-it forces the recreation and out-äoor action that might not be had in any other way; hence this book treats largely of fishes and fishing, the preeminent recreation of the northwest for men, women and children, for it takes one to the woods and streams where nature's attractions will do the work of restoring her tired children to vigor and health.

The book tells of fishes in such a way as to familiarize all readers with the subject and instruct, the young as well as the old, in the art of angling, boating, camping and woodcraft, as applied to the northwest.

Not many persons in the Northwest know the names or habits of the fishes found in the lakes and streams of Minnesota, Wisconsin and other western states. Not a single person, not even the old experienced fisherman, can tell the name of every fish he catches.

This book contains the most valuable information on this subject ever printed. It shows accurate pictures and gives brief descriptions of the principal fishes embraced in the western states, though not all of them; and more, it tells how to catch these fish, the kind of bait to use and how to prepare these fish. Experience gathered from scores of the most successful and investigating anglers of the present generation. It is told plainly, without touching on the science of the subject.

In addition this book contains practical information concerning camping, camp cooking, boating and boat building, wood craft, etc.; tells the amateur what to take on an outing and what not to take and contains a synopsis of the game and fish laws of all western states. 


\section{KNOWN BY IMANY NAIMES.}

The attention of readers of this book is called to the fact that nearly all fishes are known by a variety of names, which have been applied locally; for instance, the common sand pike found in the Mississippi river is also known as sand perch, jack salmon, glass eye, etc. The common names here applied to fish are those adopted by the United States Fish Commission. Every resource at the command of the author has been drawn upon to make the description of the fishes herein, accurate so far as investigation has progressed. When it is known that some five thousana new varieties of fish are being discovered every year by the fish commission's agents, and that many of these are annually found in the streams of the middle west, it is easy to comprehend how many of the small fish of the sucker family cannot be distinctly and accurately described in a small volume. It is estimated that there are twenty-five varieties of suckers in the lakes and streams of Minnesota and Wisconsin. Many of these never grow to more than three inches in length. They are all classified as minnows-shiners, chubs, etc. 


\section{WHIPPING TROUT STREAIMS.}

Any angler for trout, if he has had experience, must know that while it is great sport it is also hard work. The hills to climb, underbrush to crawl through, dead trees and marshes to cross, streams to ford, and long walks, must be part of the work in trout fishing. The streams are wild, in places the current is shallow and swift, while in others are found silent pools of varying depths. Then there are the clouds of flies, gnats and mosquitoes which are alone sometimes enough to dampen the enthusiasm of the angler and force him into declaring that he will never again go trout fishing. But he goes again and again, for it is the successful accomplishment of the undertaking that lures him on, and soon the difficulties in the way become matters of course. However, there are some streams more easy of access than others, but the old angler looks upon these as the special preserves of women trouters, and will look for something more promising and more to his liking.

Every fly fisherman knows how necessary it is to be out of sight of the trout, especially on bright days. It is on that account a good plan to 'wade up stream, making casts well in advance, so that no disturbance of the water may convey intelligence of approaching danger. The flies should be very small, and three of them may be used at once, in order to offer some variety.

But the eye of the trout is a quickly adjusted microscope: and is speedy in detecting any fault in the make-up of the fly, or in the manner of its alighting upon the surface. Only experience will teach the fisherman the turn of the tip of the rod, which checks the fall of the leader, and allows the flies to come naturally to the stream.

There is a fly well known to anglers, which has a very tiny bit of woodcock's feather tied in, along with a black and a yellow hackle. The insignificant brown bit looks as though it might be successfully imitated by a tip from a partridge or a brown Leghorn hen, but all practical men who have tried it know that nothing but the real woodcock plume will answer for that fly. 


\section{HOW TO ANGLE FOR TROUT.}

This is a subject on which anglers ciiffer as to detail and tackle. Brook trout are very shy of unusual noises and the man with rod and reel must keep out of sight and make as little noise as possible.

Besides knowing the signs of likely places, and knowing how to cast the line, the tackle is the greatest consideration in trouting. The rod should be nine to twelve feet in length, depending upon the locality to be fished. Expert fly and bait casters prefer the shorter rod, for it is much easier to take care of when traveling through the underbrush. The long rod is preferred by many, but the lightest of these soon tire the wrist. They are usea in "spotting," more than in casting. A line about the length of the rod is swung out to the desired pool. With the shorter and lighter rod one may cast considerably farther than with the long rod, and the latter seems more desirable when the fly is used, more natural results following such casts, while the use of the reel is more satisfactory. Next to the rod, the line must have careful consideration, and here again anglers are at odds. A fine sillk braided line is preferable to the twisted line for two reasons, at least. It will run off the reel smoother and is less likely to kink where it is twisted by a swift current, and consequently will reel in better. A twisted horse hair line containing nine hairs is a fine line but very expensive.

A free running reel is also necessary, and these may be of the kind suited to the owner's taste and pocket book. The line and reel, however, should be in "sympathy." Some lines will not work at all satisfactory with some reels, though they would do perfect work with others. Experiment on this subject will repay the angler-and he only can say when he has found the two that are in harmony.

Next, the bait is to be decided upon. Live bait and artificial bait are in use and of varieties there are many. The chub minnow, angle worm, white grub worms, the flesh of deer, rabbit or any wild fowl, shrimp and crawfish, or grasshopper, will bring a strike at certain seasons of the year. At the opening of the season in the western states, angle worms are most available, or the little white worms found under the moss on rocks lying below the surface of the water. Minnows are also to be had wherever trout are found. In fact, in many streams abounding in trout "chubs" of good 
size will take the bait as often as the speckled game. The smaller chubs make good bait for large trout.

A month later, unless the season is very forward, the artificial fly will give the angler greater sport than live bait and cause him less inconvenience. Of artificial flies there are hundreds of varieties made of as many different materials, but all made in imitation of natural flies and for localities in which these flies abound, from the size of a housefly to a butterfly. One should have a variety of these. If the trout do not rise to one, try another. A fly that trout may take in the morning, it will sometimes not touch at noon or evening. A little brown sandfly is quite a catch at certain times, while the white miller or black moth gives good results at other times. It has been said by many trout anglers that best results come from using a bright colored fly on a cloudy day and a dull colored fiy on a bright day. Yet, the reverse has proven equally successful.

Some anglers use a single fly or hook, while others use the tandem-two or three-attached about twelve inches apart, though the distance separating the hooks is a matter of opinion and conditions under which the angling is done. It is undoubtedly true that mere trout will be taken with the tandem hook than with the single hook. Often a trout is taken on each hook, where trout are very numerous.

A landing net and creel are essential adjuncts to the trouting equipment, and if streams are to be waded, which is generally the case, wading boots are necessary.

Now a few words on angling, just to help the amateur. After the equipment is secured the beginner should consult some experienced angler and ask all the questions he can think of. That done, he can go ahead. Fish down stream generally, but there are times and conditions under which one may win greater success by casting up stream, though such instances are rare. Before starting, practice casting. This may be done anywhere that space may be found. Practice makes perfect and any one who is trouting cannot have too much experience. It is difficult work, but very essential to success. After this learn all about the stream you intend to whip-the holes, pools, etc., and go ahead. Experience will do the rest. 


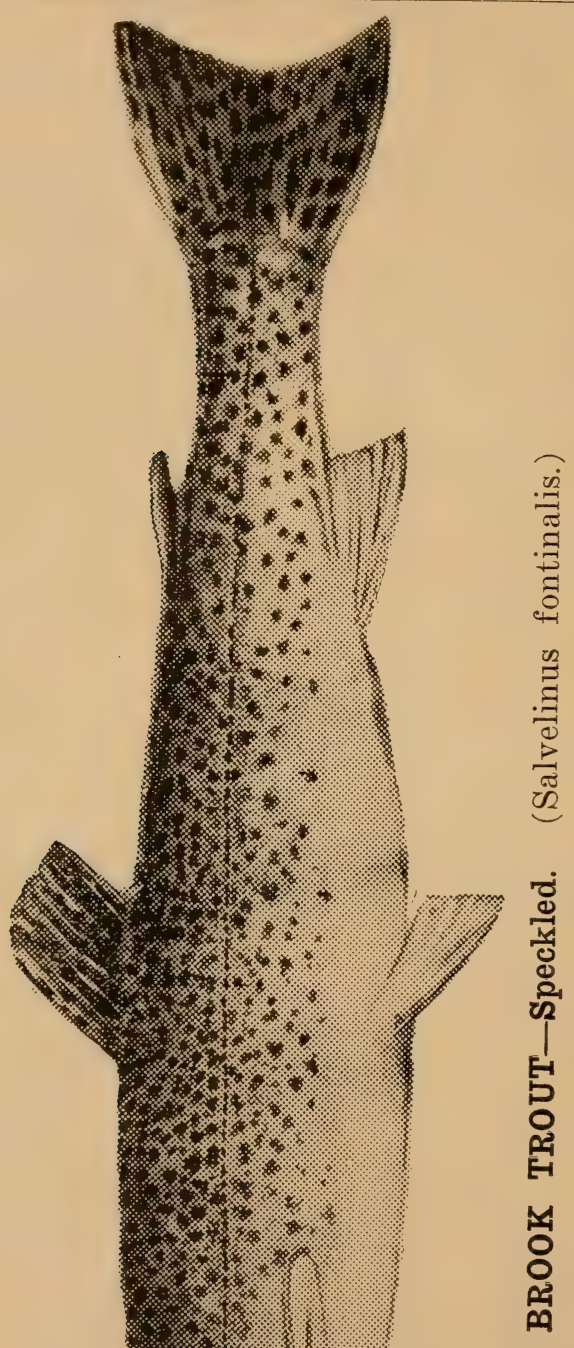




\section{BROOK TROUT.}

The Brook trout of Minnesota, Wisconsin and Michigan range from light gray in color to greenish black, depending on the waters and the food on which they live. It is undoubtedly the various shading of colors that has caused many anglers to call some of them "Mountain trout." Indeed they are found in swift running streams in these states identical in every marking with those found in the Mountain streams of the west. They are marked with red and gold spots, the spots on the lighter color showing more prominent than on the darker fish. They range in weight from one-quarter of a pound to three and a half or four pounds, though the average weight is not above half a pound.

The brook trout or speckled trout (Salvelinus fontinalis) is one of the most beautiful, active, and widely distributed of the American trouts. It prefers clear, cold, rapid streams, and belongs to that group of trout known as charrs, characterized by the presence of round crimson spots on the sides of the body. Other members of this class are the saibling or charr (Salvelinus alpinus) of Europe and Greenland; the Sunapee trout (S. alpinus aureolus), found in parts of New Hampshire and Maine; the blueback trout (S. oquassa) of the Rangeley Lakes in Maine, and the Dolly Varden trout, red-spotted trout, or bull trout (S. malma) of the Pacific States and Alaska. T'he lake trout also belongs in this group.

The general form of the brook trout's body varies considerably, sometimes being elongated and sometimes rather short, but the usual depth is about one-fourth or one-fifth of the length. The head is large and blunt, and is contained $4 \frac{1}{2}$ times in the body length. The large terminal mouth is provided with teeth on the jaws, tongue, and palate bones, and also with a small patch on the vomer. The eye is placed high in the head; its diameter is about one-sixth of the length of head. The gill-rakers on the first arch number about 17 , of which 11 are on the lower arm. The scales are very small and numerous; about 230 are in the lengthwise series, and 35 above and 35 below the lateral line. The dorsal and anal rays are 10 and 9 , respectively. The tail is square or slightly lunate in the adult, forked in the young.

There is considerable variation in the color of the brook trout, dependient on local conditions, sex, and age. The head, back, and sides of the body, dorsal and caudal fins are of a grayish or greenish color; the back, head, dorsal, and base 
of catudal are mortled with iark green or black. In the male there is a reddish band along side of belly. Along the middle of the side there are numerous round light-red spots surroundeci by whitish or light-brownish circular areas. The lower lins are dusky, with a pale or cream-color anterior border bounded by a black streak; remainder of fin often red in breeding males.

The brook trout may be distinguished from the other charrs by the dark-brown or black marblings on the back and the general absence of spots on the back.

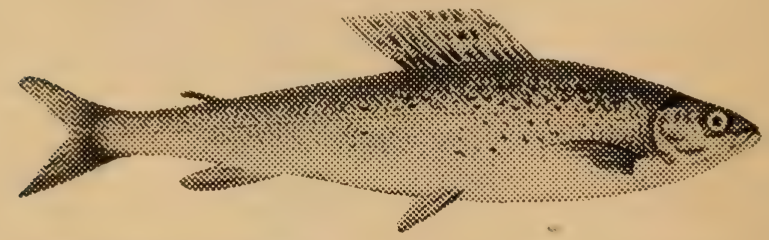

THE GRAYLING. (Thymallus ontariensis.)

The Michigan Grayling (Thymallus ontariensis) is natural. ly found only in certain streams in Michigan, although the type specimen was said to have come from Lake Ontario. It is one of the most attractive and game of fresh-water fishes, but is rapidly approaching extinction, owing to excessive fishing and the pollution of streams, which have not been counteracted by artificial propagation. The Montana Grayling (Thymallus ontariensis montanus) inhabits a limited area in the head-waters of the Missouri River and is very abundant in some streams.

Although the cultivation of the grayling was begun as early as 1874 , it was never regularly or extensively conducted. Spawning in Michigan occurs in April, and the eggs are normally laid in gravel beis in clear, cold streams. The number of eggs taken from a single fish varies from 3,000 to 4,000 . The same methods of culture pursued with the brook trout are applicable to the grayling. In water having a temperature of 50 to 60 degrees $\mathrm{F}$., the incubation is 14 to 20 days. 


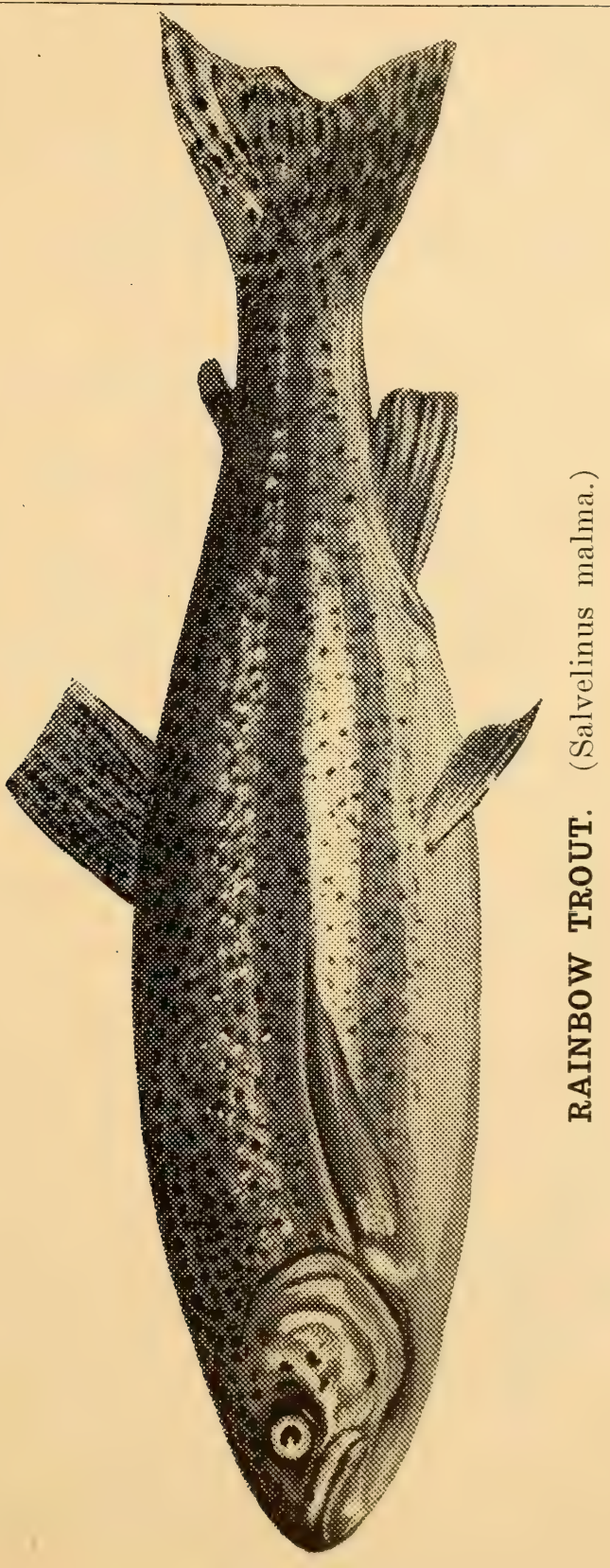




\section{RAINBOW TROUT.}

The Rainbow trout of Minnesota and Wisconsin is one of the most beautiful fishes found in western waters. Its body is striped with beautiful tints of rainbow colors the entire length, while the spots found on the "speckled" trout show much less color on the rainbow. Wherever these fish are found they range in weight similar to those of the "speckled" trout.

The body of the rainbow trout is comparatively short and deep, and is more elongate in males than in females. The average depth is contained about three and four-fifths times in the body length. The snort head, which is obtusely ridged above, is about one-fourth the total length. The mouth is smaller than in species of Salmo, the maxillary reaching scarcely beyond the eye, which is rather large, and is contained five times in the side of the head. The caudal fin is distinctly but not strongly forked. On the vomer are two irregular series of teeth. The dorsal rays number 11 and the anal 10 . In the typical species there are about 135 scales in the lateral series, with 20 rows above and 20 below the lateral line; in the several subspecies the number of rows of scales along the side is from 120 to 180 . The color is variable, depending on sex, age, and character of water. Typical adult fish are bluish above, silvery on the sides, profusely and irregularly darkspotted on the back and sides, the spots extending to the vertical fins, with a red lateral band and blotches and a neariy plain belly.

The rainbow trout is not indigenous to eastern waters, its original habitat being the Pacific Coast of the United States. It is especially abundant in the mountain streams of California. A few specimens, however, have been taken in salt water, and it is not unlikely that some find their way through the rivers in to the sea.

This fish is a native of the Great Lakes, but during the past decade attempts have been made to transplant the fry in the smaller lakes of Minnesota and Wisconsin, with some degree of success where the water is cool and deep.

This handsome species (Cristivomer namaycush), the largest of the trout, is classed with the charrs. It has an elongated body, the length being about $4 \frac{1}{2}$ times the depth. The head is large, flat above, and about as long as the body is deep. The mouth is large; the maxillary bone extends beyond the eye and is half the length of the head; the jaws have 
strong teeth. A peculiarity of the vomerine bone distinguishes this fish from the genus Salvelinus; it has a crest provided with teeth extending backward from the shaft of the bone. On the hyoid bone the teeth are in a cardiform band. The eye, placed near the top of the head, is contained about $4 \frac{1}{2}$ times in length of head. The caudal fin is well forked. Both the dorsal and anal fins contain 9 to 11 rays. In the straight lateral line there are about 200 scales. Branchiostegals 11 or 12.

The coloration is quite variable in fish from different localities. The general color is usually dark gray. The body, head, and fins are covered with small discrete rounded spots, usually of a pale color, but often tinged with reádish. On the back and top of head there are fine vermiculations, as in the brook trout. Examples from some lakes of Maine and eastern Canada are nearly black, anid Alaskan examples are often very dark; others are quite pale.

That variety of the lake trout known as the siscowet (Cristivomer namaycush siscowet), found only in deep water in Lake Superior, is shorter and paler than the typical fish anä has weaker teeth and a shorter head; it is, however, chiefly characterized by an excessive fatness, which greatly reduces its food value. 


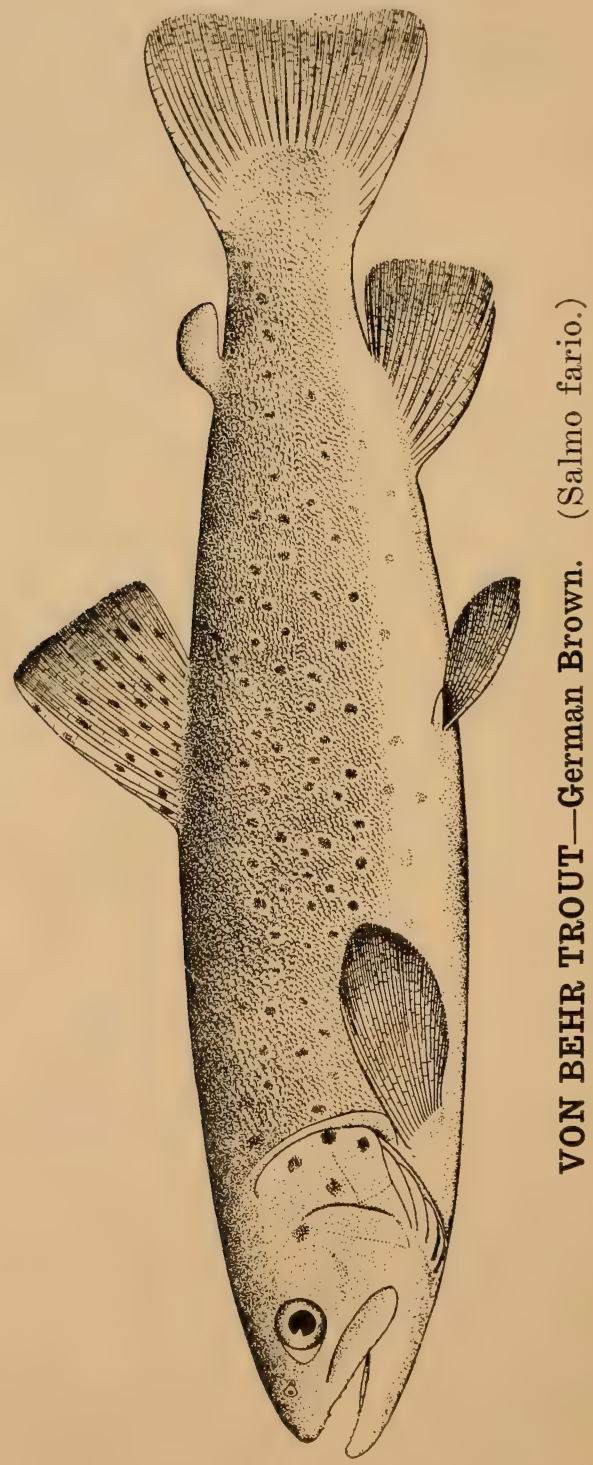




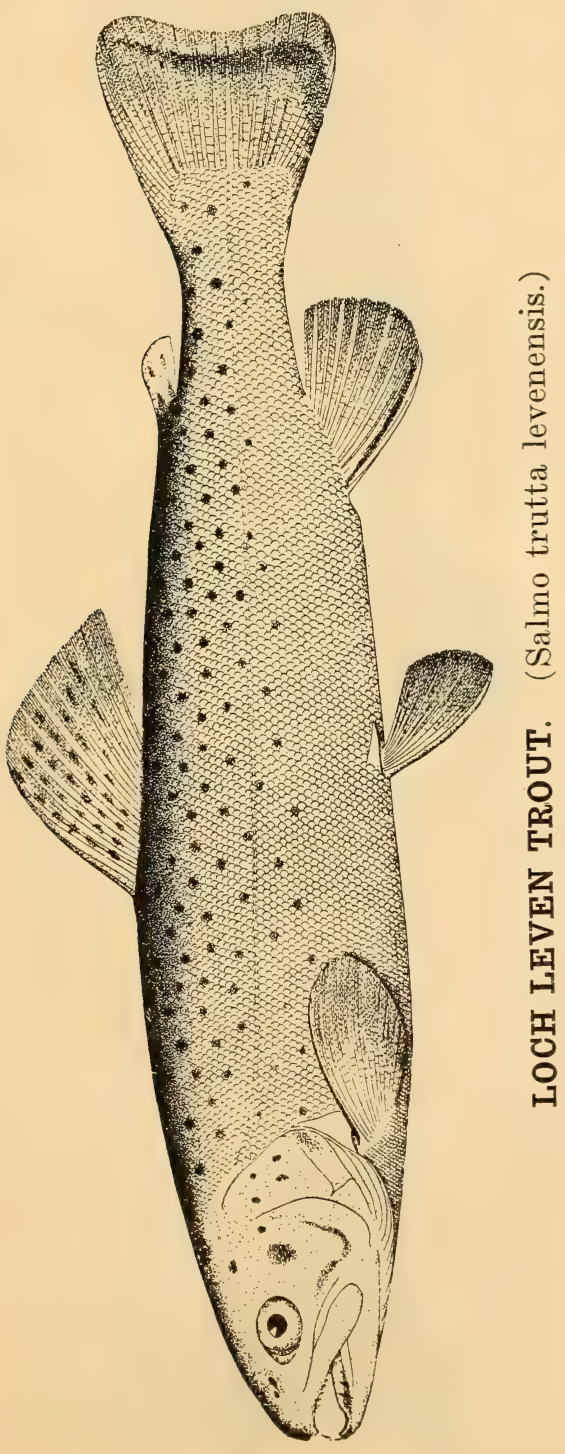




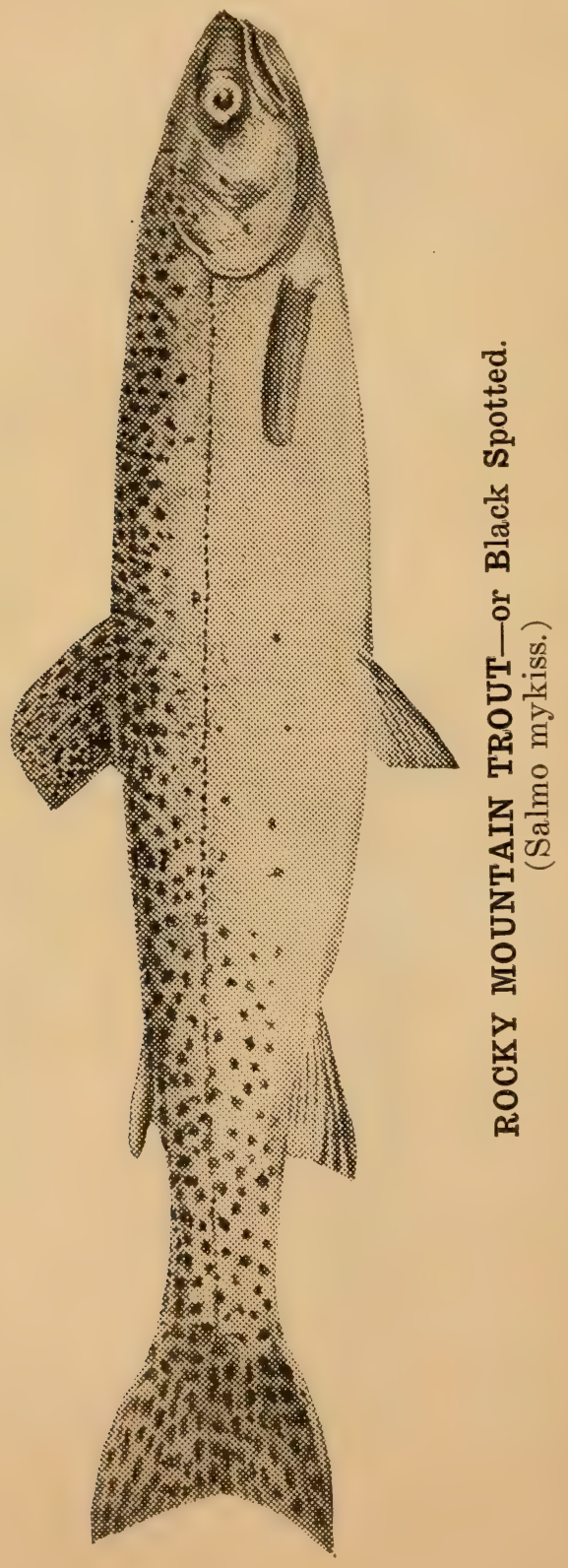






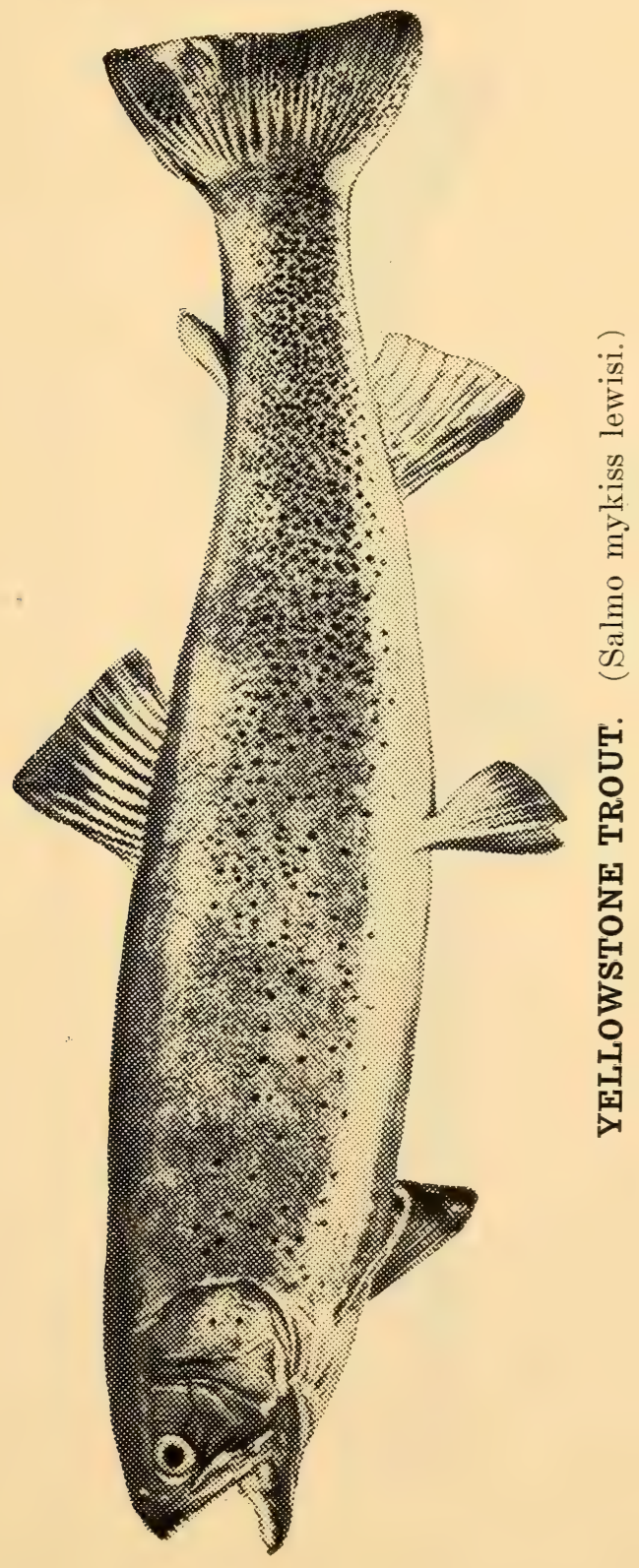




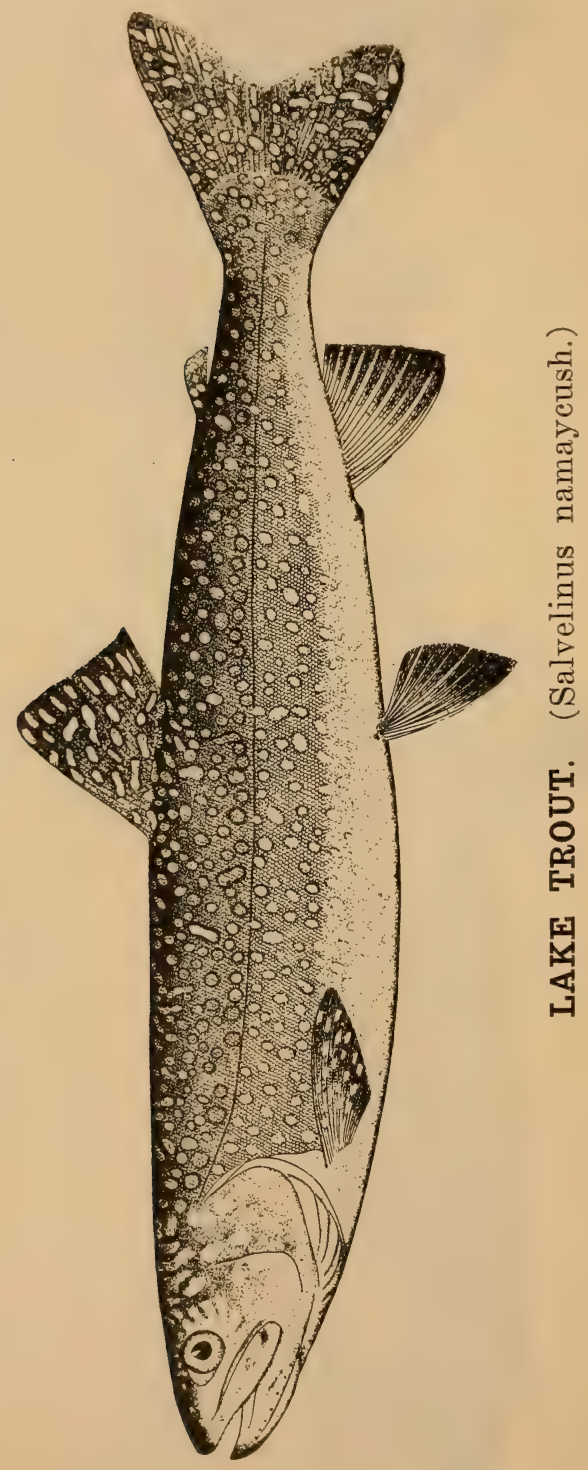




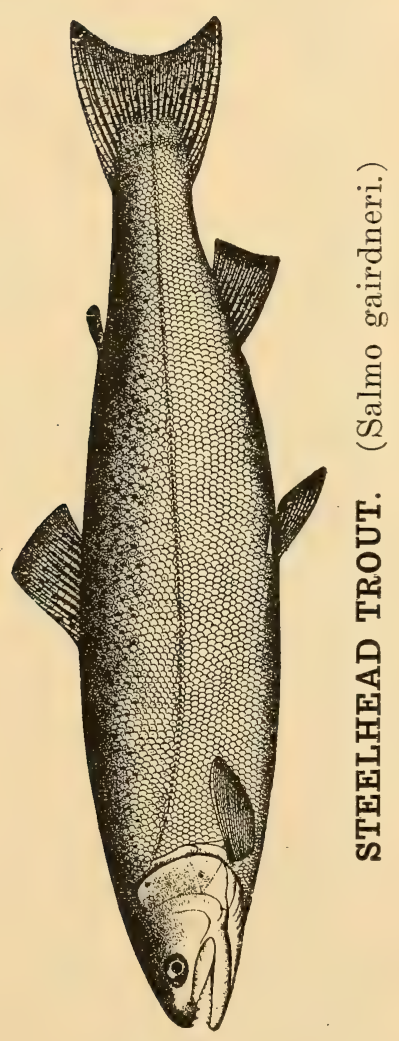




\section{VON BEHR TROUT-German Brown.}

\section{(Salmo fario.)}

This trout grows to large size and is found in many of the streams of Wisconsin. Specimens have been taken, in Wisconsin, weighing six pounds, though the average weight is three-quarters of a pound. Von Behr trout have been caught weighing twenty pounds in the waters of California.

\section{LOCH LEVEN TROUT.}

(Salmo trutta levenensis.)

This fish is very similar to the Von Behr or German brown trout. Fry has been planted in many of the western streams. This is claimed to be the most gamey of all trout.

\section{ROCKY MOUNTAIN TROUT—or Black Spotted.}

\section{(Salmo mykiss.)}

This trout is similar to the brook trout of Minnesota and Wisconsin except that its spots are mainly above the middle of the body and wholly cover the tail and dorsal fin.

\section{YELLOWSTONE TROUT.}

(Salmo mykiss lewisi.)

Yellowstone trout are found in the tributaries of the Yellowstone River and in many of the streams and lakes of the Yellowstone National Park. It is sometimes known as the "Cut Throat" trout and is a vicious fighter. Its spots are smaller and more numerous than the Wisconsin brook trout, and is much darker.

\section{STEELHEAD TROUT.}

(Salmo gairdneri.)

A few of these trout have been planted in the brooks of Minnesota and Wisconsin. The Steelhead is black on the back shading to a dull gray on the sides, while the head is of clear steel gray resembling the polished metal. They are found in Montana and along the Pacific Coast as far North as Alaska. The fish is large and black spotted. It is also known as "hardhead" and Gairdner's trout. It is also a Russian fish where it is known as Soomga. In some of the Eastern markets it is sold as Kennebec salmon. It sometimes reaches a weight of thirty pounds. 


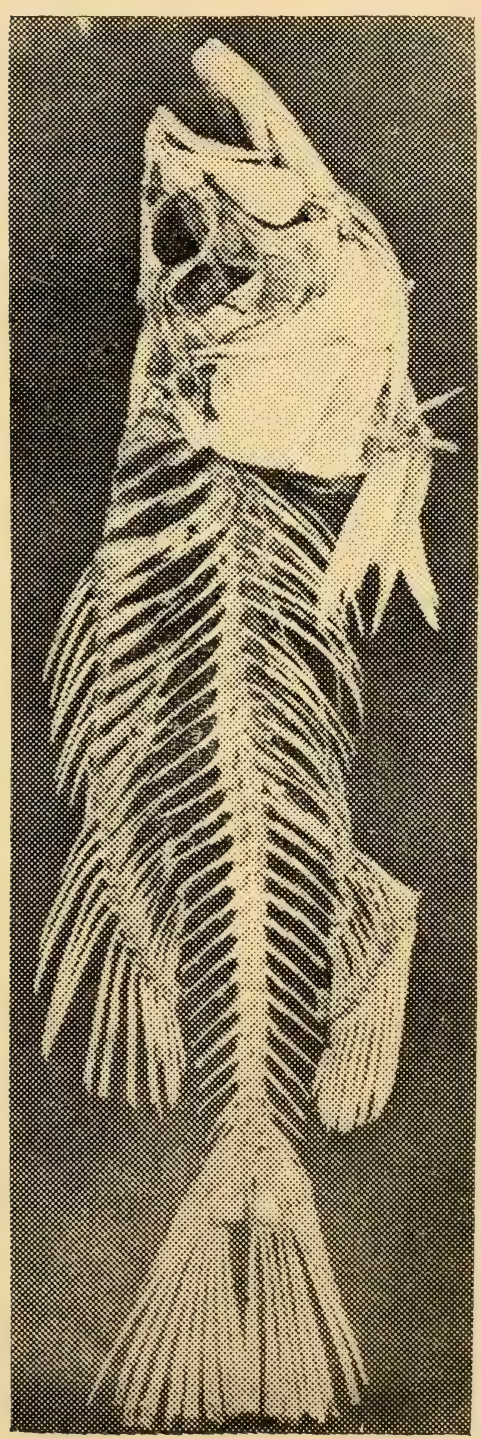

린)

ีำ

อี $\Xi$

ह

ఏ

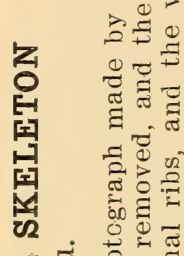

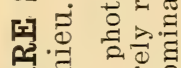

뱉유유

द잉 뮤유

되 흔 क्र

될 을

퍼 000

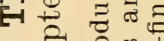

다 은 근 $\frac{1}{\pi}$

0 잉 है

及棌

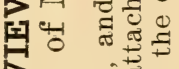

$P \quad 0$

स ज记

ली त्व

다 छ

E

म $\quad 0$ है

EI कृष

च

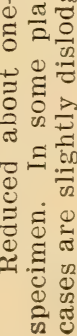




\section{THE BASSES.}

T'he species treated of in this chapter are those members of the Centrarchidae (or fresh-water sunfishes) which have come under the scope of fish-culture, namely, the large-mouth black bass (Micropterus salmoides), the small-mouth black bass (Micropterus dolomieu), the rock bass(Ambloplites rupestris), the crappie (Pomoxis annularis), ano the calico bass (Pomoxis sparoides). Whatever is said of the rock bass will apply enually to other sunfishes, which might be here considered but which have not been artificially reared.

The principal physical characteristics of these fishes are inaicated in the following key, which serves to distinguish the two species of black bass and the two species of crappie from each other as well as from less closely relateã species.

Large-mouth black bass: Body comparatively long, the depth about one-third the length; back little elevated; head large, 3 to $3 \frac{1}{2}$ in body; eye 5 to 6 in head; mouth very large, the maxillary in adults extending beyond eye, smaller in young. Ten rows of scales on the cheeks; body scales large, about 68 in the lateral line, and 7 above and 16 below the line. Dorsal fin low, deeply notched, larger than anal, with 10 spines and 12 or 13 soft rays; anal with 3 spines and 10 or 11 rays. Color above dark-green, sides greenish-silvery, belly white; young with a blackish band along sides from opercle to tail, the band breaking up and growing paler with age; caudal fin pale at base, white on edge and black between; older specimens almost uniformly dull greenish; three dark oblique stripes across opercle and cheek; dark blotch on opercle.

Small-mouth black bass: Similar in form to large-mouth bass. Mouth smaller, the maxillary terminating in front of posterior edge of eye, except in very old specimens. About 17 rows of small scales on the cheeks; body scales small, 11-74-17. Dorsal fin less deeply notched than in other species, with 10 spines and 13 to 15 rays; anal with 3 sipines and 12 or 13 rays. General color dull golden-green, belly white; young with dark spots along sides tending to form irregular vertical bars, but. never a lateral band; caudal fin yellowish at base, white at tip, with dark intervening area; dorsal with bronze spots and dusky edge; three radiating bronze stripes extending backward from eye; dusky spot on point of opercle.

Crappie: Body short, greatly compressed, back much elevated; depth $2 \frac{1}{3}$ in length; eye large, one-fourth length of 
head; head long, 3 in length; profile with double curve; mouth large, snout projecting. Scales on cheeks in 4 or 5 rows; scales in lateral line 36 to 48 . Dorsal fin smaller than anal, with 6 spines and 15 rays, the spirous part the shorter; anal with 6 spines and 18 rays; dorsal and anal fins very high. Color silvery white or olive, with mottlings of dark green; the markings mostly on upper part of body and tending to form narrow, irregular vertical bars; dorsal and caudal fins with dark markings; anal nearly plain.

Strawberry bass: Similar in form to crappie, but the body shorter, back more elevated, and profile of head straighter; repth, one-half length; head one-third length; mouth smaller than in crappie; snout less projecting. Six rows of scales on cheeks, and 40 to 45 along lateral line. Dorsal and anal fins higher than in crappie; dorsal spines 7 or 8 , rays 15 ; anal spines 6 , rays 17 or 18 . Color, light silvery-green, with darkgreen irregular mottlings over entire body; dorsal, caudal, and aual fins with dark-olive reticulations surrounding pale areas; whole body sometimes with a delicate pink reflection (hence the name strawberry bass).

Rock bass: Body oblong, compressed, back moderately elevated; depth 2 to $2 \frac{1}{2}$ in length; head large, $2 \frac{3}{4}$ in length; eye very large, $3 \frac{1}{2}$ in head. Scales $5-39-12$, in 6 to 8 rows on cheeks. Dorsal fin much larger than anal, with 11 spines and 10 rays; anal, with 6 spines and 10 rays. Opercle ending in two flat points; gillrakers less than 10. Color olive-green, with krassy reflections; young irregularly barred and blotched with black; adult with a dark spot at base of each scale, forming interrupted and inconspicuous stripes; a black spot on opercle; anal, caudal, and soft dorsal fins with dark mottlings.

The most reliable rule for distinguishing the largerouth from the small-mouth bass is the number of rows of scales on the cheeks. The colors of each species vary with age and the size of the mouth varies with the size of the fish, bui the scales are constant under all conditions. With the crappies, the leading differential feature is the number of dorsal spines.

I3y reason of their wide geographical range, the black basses have received a multiciplicity of popular names. The large-mouth black bass is known as Oswego bass, lake bass, green bass, yellow bass: moss bass, bayou bass, trout, jumper, chub, and welchman. In the North it is generally called black bass; in Virginia and North Carolina it is usually designated 
as the chub, and in Floricia and the Southern States it is often called trout. The small-mouth black bass has received the common names of lake bass, brown bass, ninny bass, hog bass, black perch (used in the mountain sections of Virginia, Tennessee, and North Carolina), trout perch, brown trout, jumper, mountain trout, together with other names of purely local use.

Rock bass are variously known as red-eye, red-eye perch, and goggle-eye, and are sometimes confounded with the warmouth (Chaenobryttus gulosus), which bears some of the same common names.

The calico bass has received the names of strawberry bass, grass bass, bitter-head, barfish, lamplighter, goggle-eye perch, speckled perch, and speckled trout. The crappie is known in its native waters as crappie, new light, campbellite, sac-a-lait, bachelor, chinquapin perch, croppie, and cropet. On account of the similarity of the calico bass and crappie, anglers and fish-culturists have frequently confounded the two, the common and local names often being used interchangeably throughout the regions to which both are native.

Possibly no common name of the black bass is more appropriate than "jumper," which is applied in certain parts of Kentucky. That both species of the black bass are jumpers is well known to every angler, but it is better understood by those who have had occasion to collect these fishes by seining. $I_{\imath} \hat{\imath}$ is almost impossible to capture them with a seine rigged in the ordinary manner, especially when the fish have the vitality and activity which is usual when living in water of moderate temperature. Like other fishes, they lose in strength and activity when they inhabit warmer waters. While the black bass of the colder northern waters make a fight worthy of the salmon, they may be taken from the waters of the south with hardly a struggle. In seining for brood stock it is well to employ a seine about three times the depth of the water, as the bagging or bellying of a seine so rigged confuses the fish and deters them from jumping.

A marked characteristic of the rock bass is their habit of settling down in dense, compact masses, resembling a swarm of bees, which is especially true of the young in cold weather. They are exceedingly pugnacious, ana sometimes seem to take the hook rather on this account than from a desire for food. They are well adapted for pond-culture, and under proper conditions will repay the culturist in a large crop of young with the expenditure of very little labor and time.

The calico bass is a fairly game fighter, and its firm, white flesh has a fine flavor when the fish is taken from cool, pure 
waters; but it is a very delicate fish to artificially propagate. It seems to resent captivity, and especially when taken from warm waters is exceedingly tender, quick to yield to attacks of fungus, and liable to become blind and die. Of large numbers collectea and transplanted in new waters many have died within a few days after being deposited.

The spawning and breeding habits of the calico bass and the crappie are so near like those of the rock bass that special remarks on the subject do not appear necessary.

\section{GROWTH AND WEIGHT.}

There is a wide difference in the rate of growth, and there is no way by which the age of a black bass can be determined from its size. Some are comparatively large from the moment they are hatched, and grow much more rapidly than the smalier members of the same school. The average size of adults varies in different localities, and sometimes will be found to vary from year to year in any particular locality. The variations depend upon initial vitality, upon the scarcity or abundance of food, and upon the range and space given the fish. At the age of 5 or 6 months the young bass measure from 4 to 8 inches, according to locality and surroundings, though a certain percentage of the crop will always run large.

Large-mouth bass have been known to weigh 23 pounds. They are not infrequently taken from the San Marcos River, Texas, weighing from 12 to 15 pounds, and a 6-pound or 8pound bass in the southern tributaries of the Mississippi and in the inland lakes of Florida excites no surprise. The smallmouth bass does not grow so large, $2 \frac{1}{2}$ pounds probably exceeding their average size, though they occasionally reach 5 or 6 pounds. The rock-bass fry grow slowly, those 6 months old seldom averaging 2 inches in length. The adult usually weighs from $1 / 2$ to $3 / 4$ pound, occasionally reaching 1 pound; and exanilles have been recorded as high as three pounds.

The crappie and the strawberry bass will, as a rule, not exceed 1 pound in weight, though in Minnesota the former has been taken as high as 3 pounds. Under like conditions of pond environment, at 6 months old the young of both these species are about the size of black-bass fry of the same age, possibly a little smaller. Each school will have a few individuals much larger than the majority.

Black bass are considered the gamiest fish to be found on the American continent, though some anglers assert that their equal is to be found in the trout of the Nippegon and the straams of the Rocky Mountains. The large mouth black bass 
(Micropterus Salmonides) and the small mouth black bass (Micropterus Dolomieu) are the principal bass fishes found in the middle western waters. They are also found in all the states east of the Mississippi River. Both these fish are good fighters and offer the best of sport to the angler on both lake and stream.

Bait casting and fly casting are the principal methods in vogue for hooking these fish. It is, at least, the method followed by experienced angiers. Trolling is often practiced, and both methods may be employed. The conditions for bass fishing govern the angler in his search for this game fish, and volumes might be written on this subject, which, after reading the amateur would have to learn by experience. The season of the year, the time of day, the condition of the weather, the direction of the wind, the contour of the lake bed and depth of the water, and many other things are considered by the successful angler.

These things must be learned by experience. It must also be understood that different baits are required at different times and uncier different conditions. The most common live bait used in the westers states is the frog, minnow or crawfish. Artificial baits are often successful where live bait will not tempt the bass to rise.

The bass fly is an artificial bait much used by old anglers and there are as many varieties of this bait as there are bugs and flies in the air. A good rod, reel and line are essential to successful angling and genuine sport. A cane pole and cotton line will "catch fish" but that is all it will do. There is something more than "catching fish" involved in the sport of angling. A smooth running reel ana a good silk line attached to a five foot rod, an assortment of hooks-the Minnesota bass hook, two or three spoon hooks, a couple of artificial baits and a half dozen bass-flies, ought to repay any one in a season for the outlay.

\section{NATURAL HABITAT AND DISTRIBUTION.}

The large mouth and small mouth black bass are widely distributed. The natural range of the large mouth is from the Great Lakes and the Red River of the North to Florida, Texas, and Mexico, and west to the Dakotas, Nebraska and Kansas. The small mouth bass range from Lake Champlain to Manitoba, and southward on both sides of the Alleghanies to South Carolina and Arkansas. The adaptability 
of these fish to extremes of temperature and their great tenacity of life under seemingly adverse conditions, has rendered their distribution comparatively easy, and they have been successfully introduced into nearly all the sections of the United States to which they were not native, and into England, France, Germany, and Finland. They have been planted in California, Washington, Utah, and other western states.

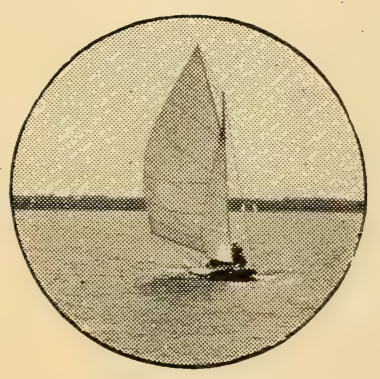




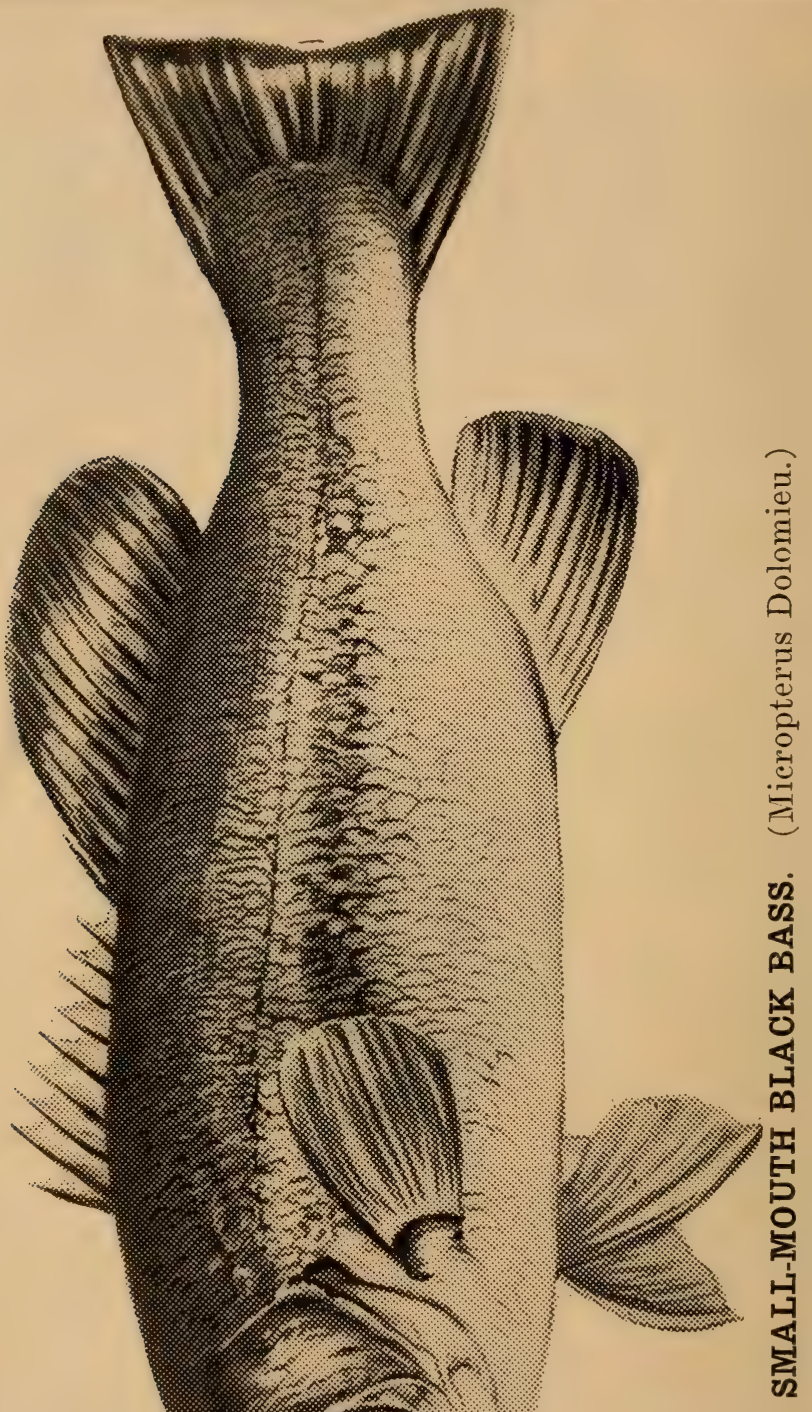




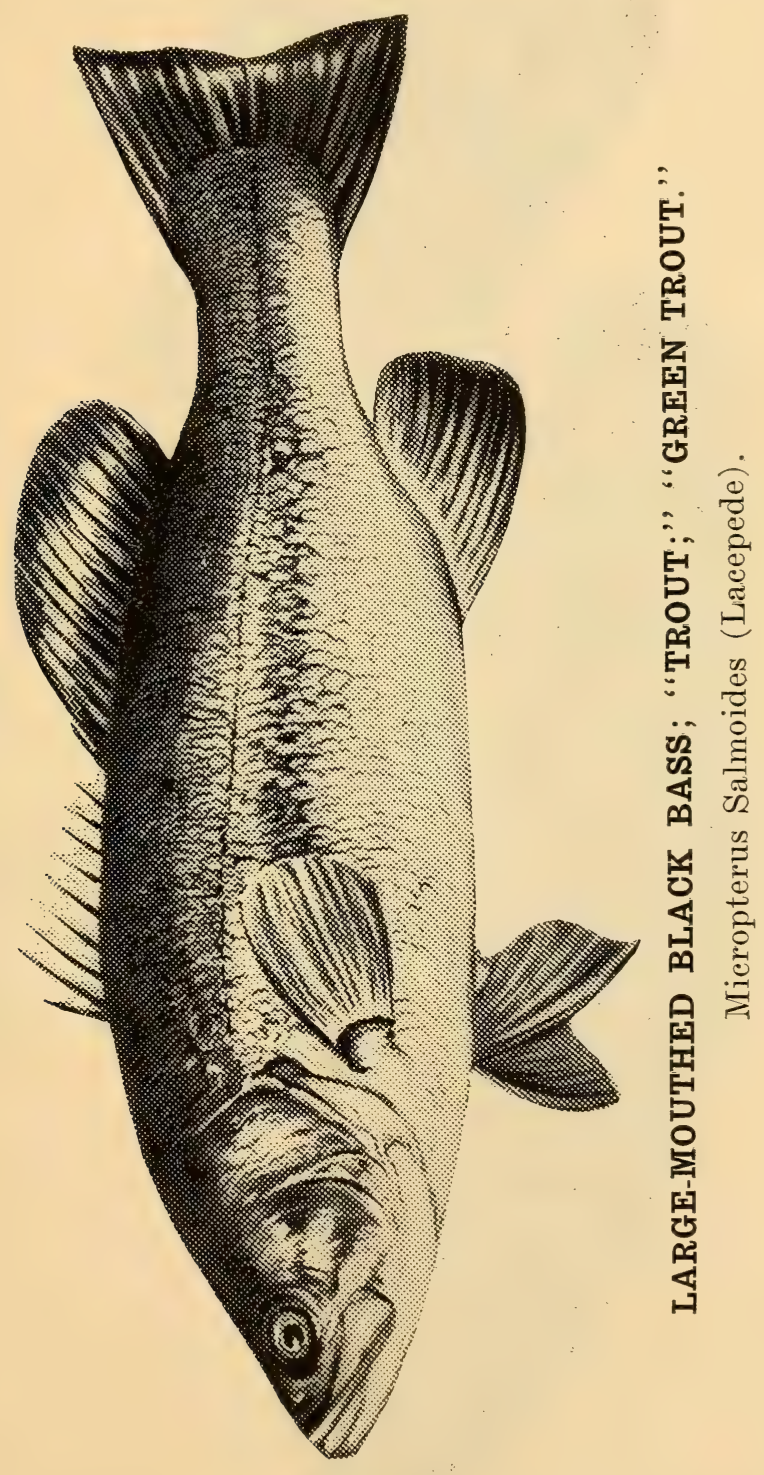




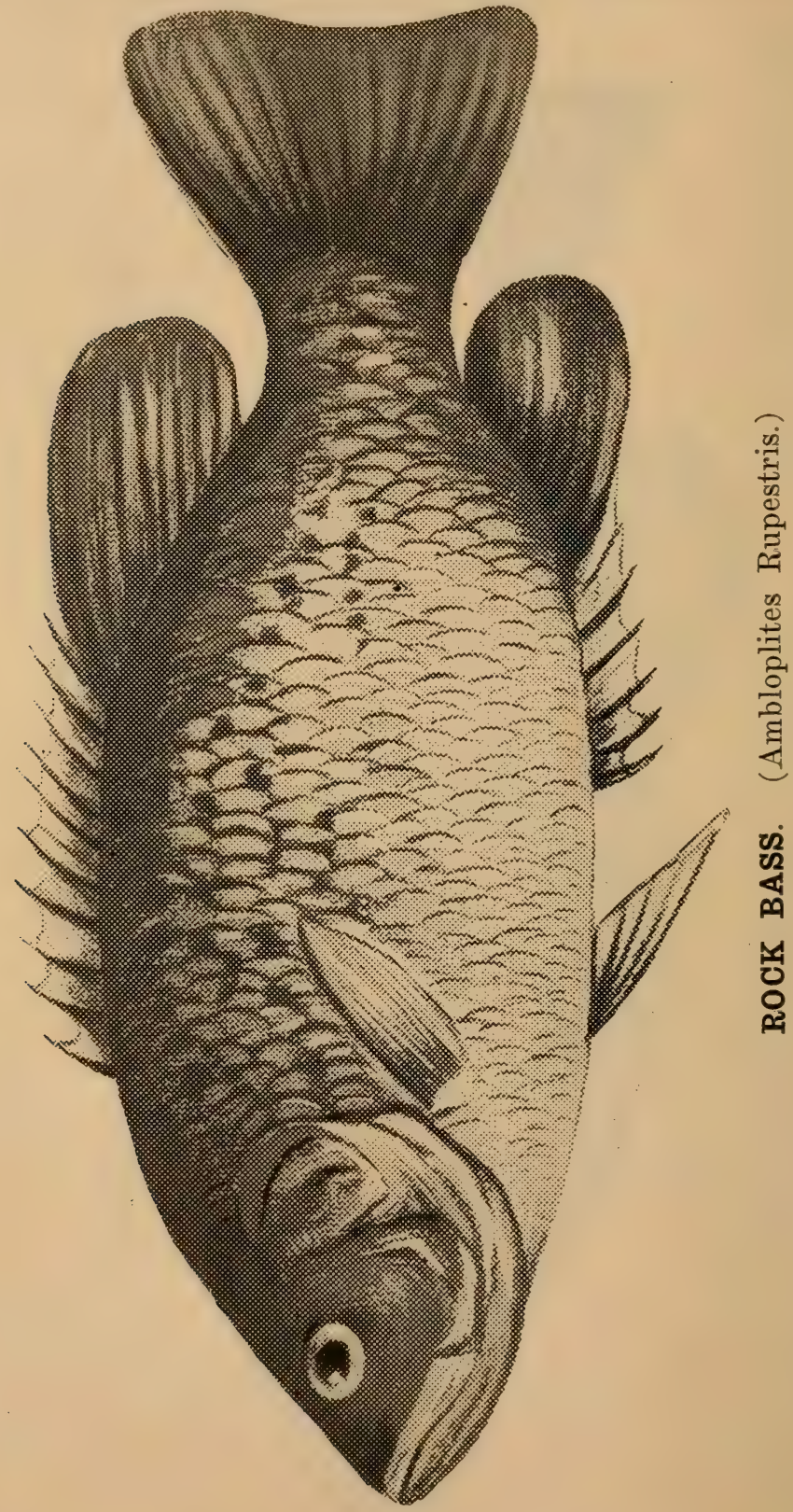




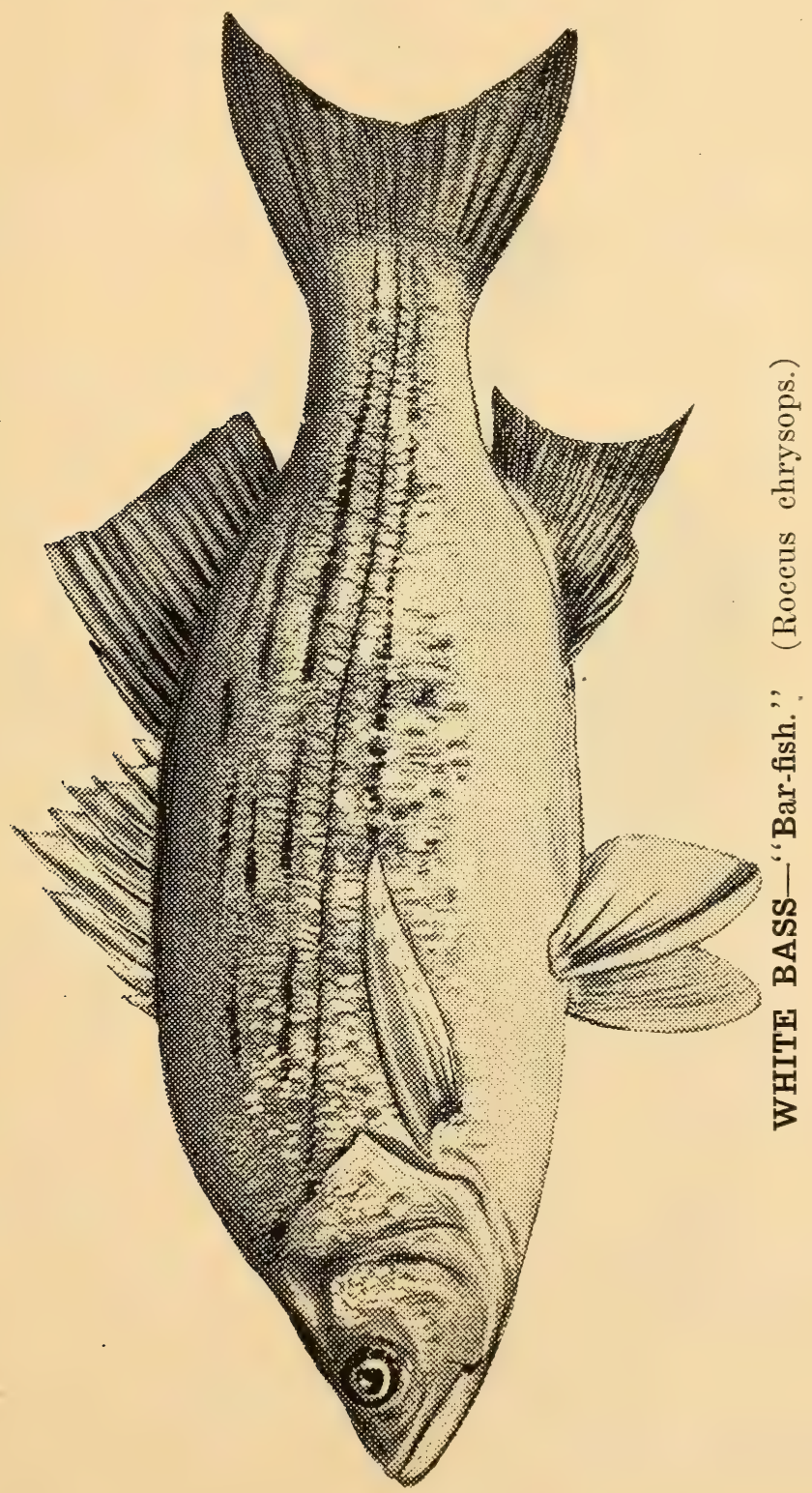




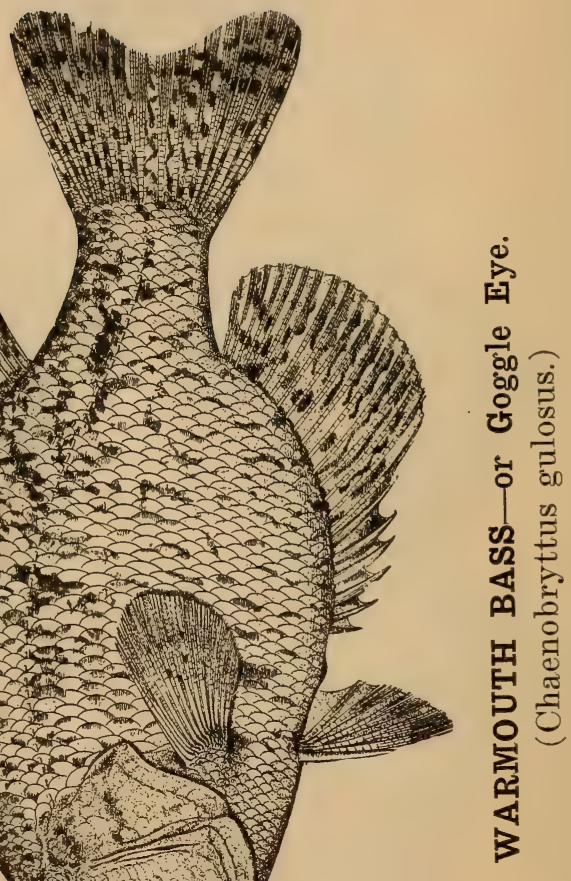




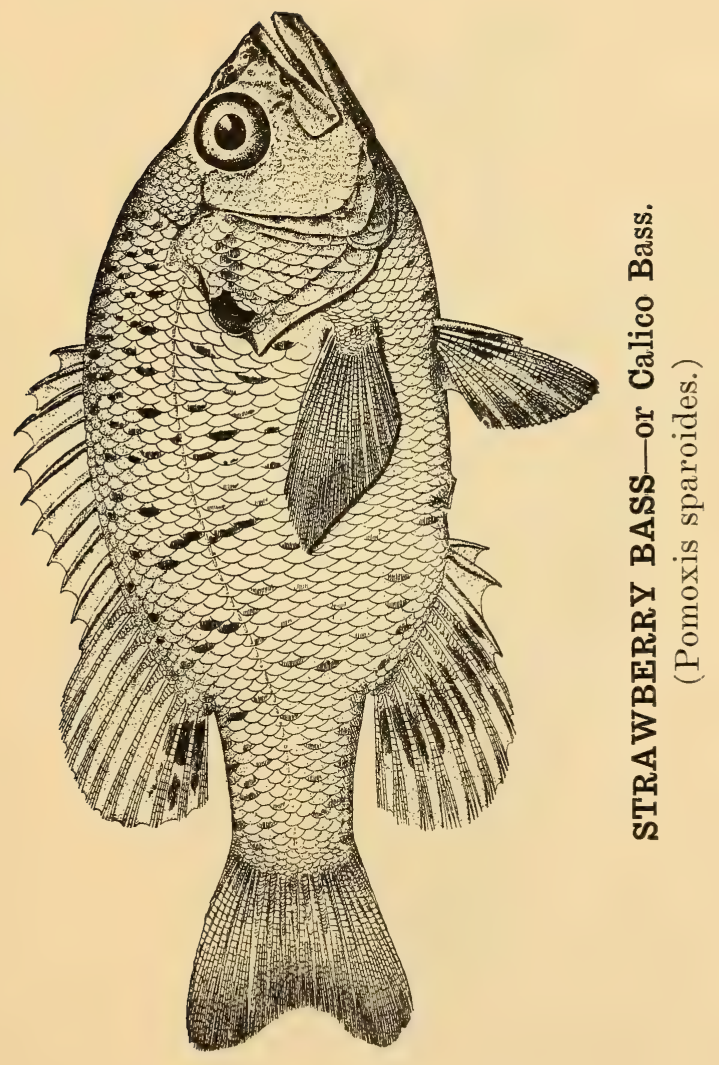




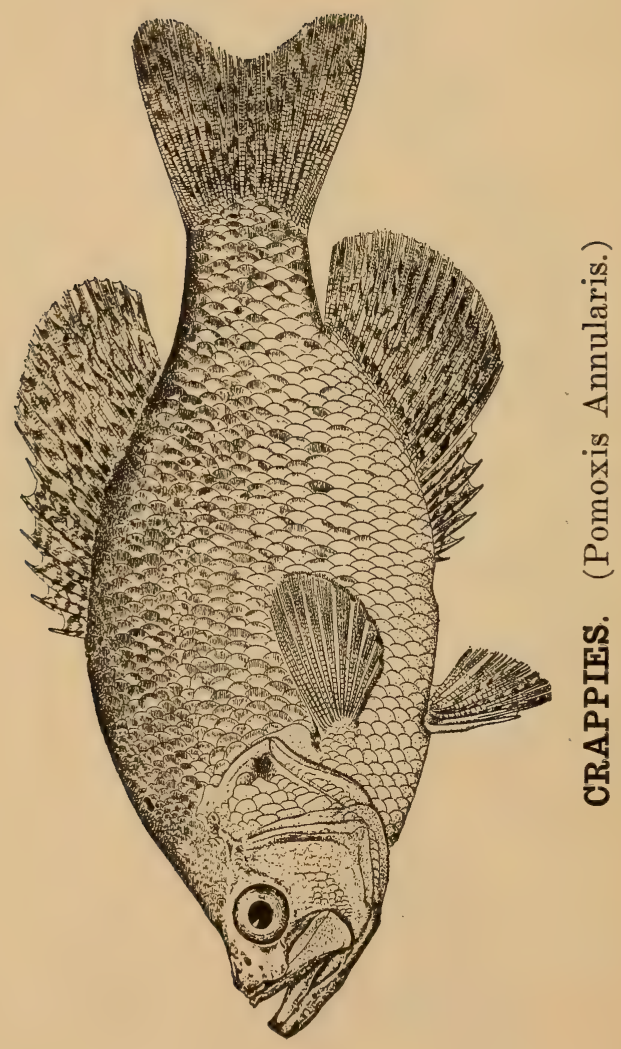




\section{CRAPPIES. (Pomoxis Annularis.)}

One of the most desirable species of the Sunfish family. These fish are generally caught with hook and line with angle worm or soft shell crab for bait, and are taken in still fishingthat is, with the boat at anchor. When found in large numbers is not difficult to land half a hundred in a couple of hours.

Another way of fishing for these fish is by fly casting, and this method affords considerable sport and requires some skill. The essential requirements are a trout line attached to a sixteen or eighteen foot cane pole, the line being the length of the pole. The common trout fly of various colors and forms are used for lures. The time for fly casting for crappies is from sundown till darkness sets in, and when the moon is very bright the crappies will strike the fly at any hour until dawn. Fly fishing for crappies during the day is unsatisfactory, though now and then one of these fish will be hooked in this way.

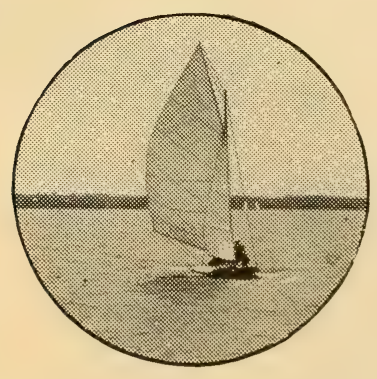




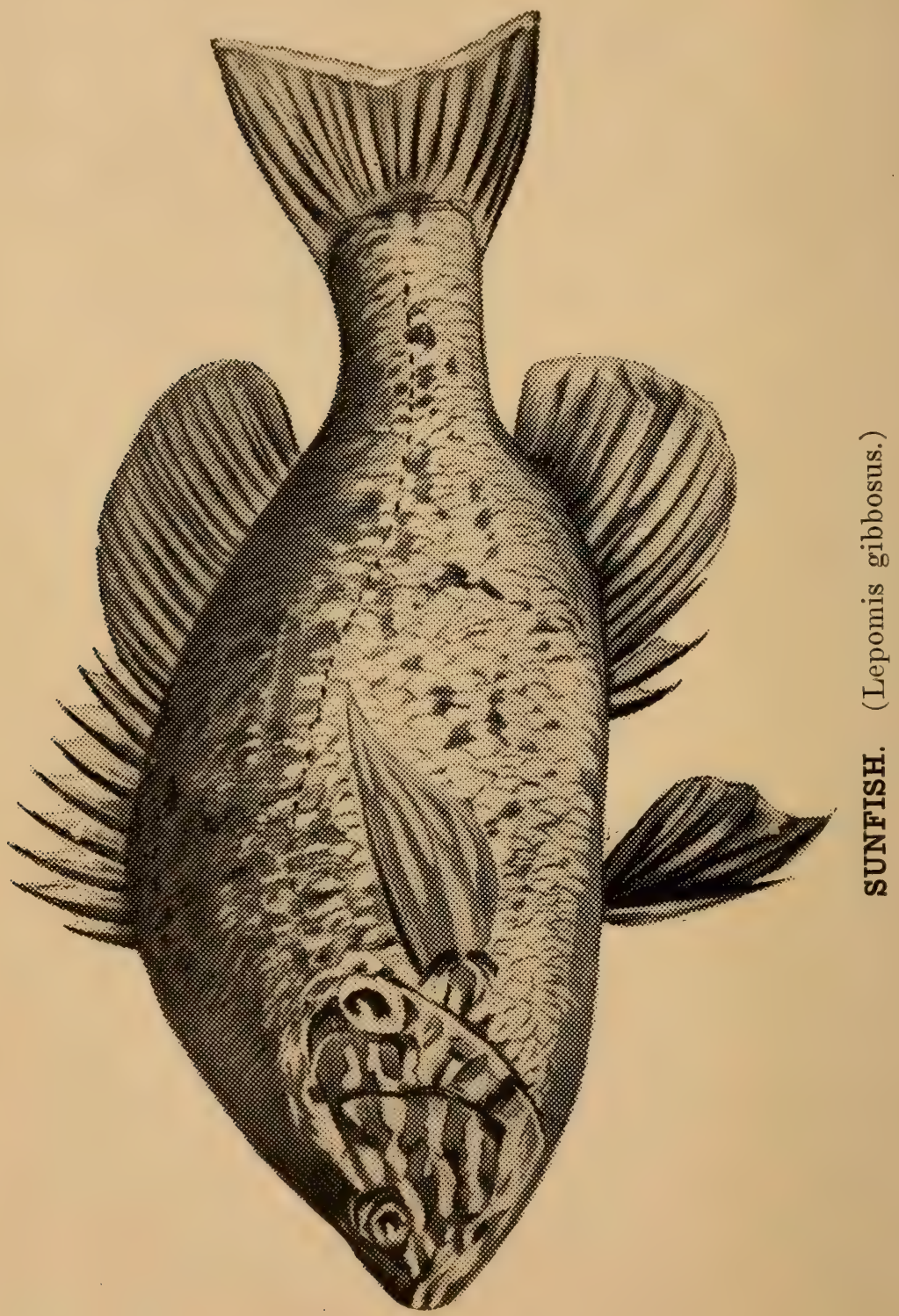




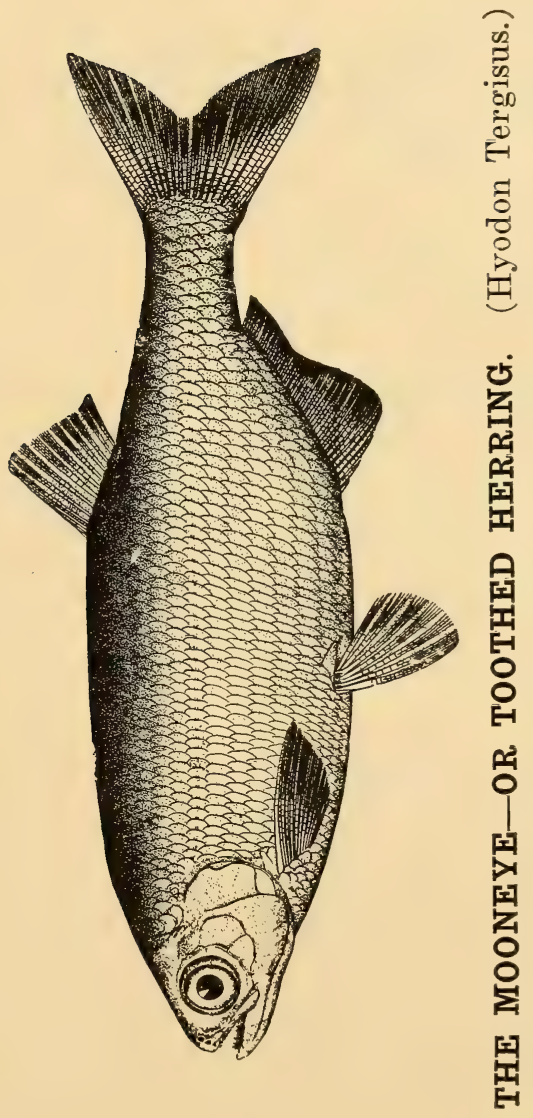




\section{WHITE BASS, or Bar-fish.}

(Roccus chrysops.)

This fish is a native of the Mississippi Valley and is found in most of the small lakes in the west, as well as in the Great Lakes. It is frequently mistaken for the small mouth black bass, though its color is a silver gray. It grows to weigh three pounds and is quite gamey.

\section{WARIMOUTH BASS, or Goggle Eye.}

(Chaenobryttus gulosus.)

This member of the Sunfish family, to which the black bass, rock bass and crappie belong, is found extensively in the western lakes an'd streams, and because of its similarity is often classed as "Sunfish" or "Crappie."

\section{STRAWBERRY BASS, or Calico Bass.}

(Pomoxis sparoides.)

This fish greatly resembles the crappie. It, like the crappie, belongs to the Sunfish family, but is of a lighter color and not as numerous. It is generally classed by "fishermen," as "Sunfish," and they let it go at that.

\section{SUNFISH.}

\section{(Lepomis gibossus.)}

This is one of the most beautiful of the Sunfishes. It has dark blue spots on the gills and is sometimes called the Blue Eared Sunfish. It is common to all western waters and is as good a panfish as can be found. They grow to weigh threequarters of a pound.

\section{MOONEYE.}

\section{(Hyodon Tergisus.)}

The Mooneyes, Golden Eyes or Silver Bass are common in the Northwest. There are three species of these fish. They are fairly good fighters and anglers like to get them on their hooks. However, they have little food value. These fish are covered with large scales, have short snout, the lower jaw extending upward, sharp teeth. They grow to weigh about two pounds. 


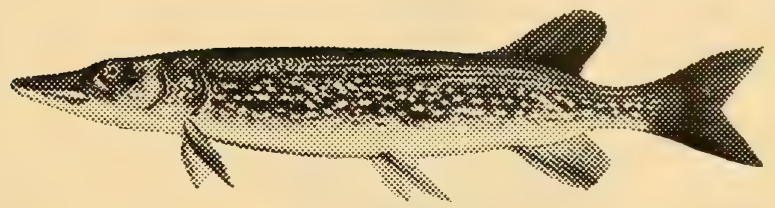

\section{THE PIKE-PICKEREL. (Lucius Rebiculatus.)}

The pickerel is a member of the pike family which has achieved a distinct name and is known everywhere as the "pickerel." A fish is found in the "Park Region" of Minnesota known as the Great Northern Pike which closely resembles the pickerel, and really there is little difference except in the markings of the two fish, a condition which is probably due to difference in food and water.

Pickerel are not regarded as game fish, but good sport may be had with them if the angler will observe a little patience. This fish will make a spurt when first hooked and then strike out for deep water and sulk. Pickerel will dart for a bait when twenty or thirty feet distant, and will take anything from an angle worm to a six inch artificial minnow. They are partial to frogs. Bass tackle is suitable for them, though great skill is required when a big one is hooked, and one should never be hasty in trying to land such a fish or the results may be a broken rod. Where pickerel are numerous it is well to use a wire snell as these big fish will often swallow a good sized hook and cut the line with their sharp, needle like teeth. Indeed, it is recommended that a wire snell six to twelve inches long be used when angling for bass, pickerel and other similar fish. 


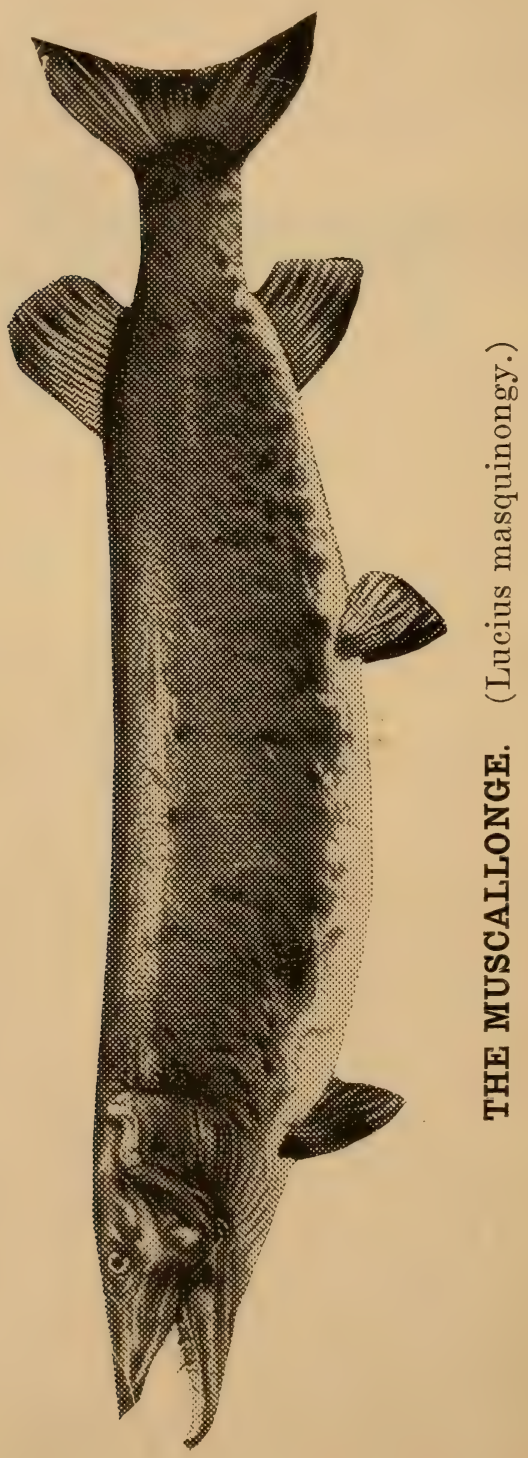




\section{MUSCALLONGE.}

The muscallonge is the largest representative of the pike family. Its maximum weight is about eighty pounds and its average weight is twenty-five or thirty pounds. Its range includes the Great Lakes, Upper Mississippi Valley, Ohio Valley, and lakes in Wisconsin, Minnesota, New York, Ontario, and elsewhere. It is much sought by anglers and is of great value as a food fish. Being provided with a very large mouth, armed with strong, formidable teeth, its food consists chiefly of living fish, which it captures by making sudden darts from its place of concealment among the waterplants at the bottom of a lake or stream.

The eggs are similar to whitefish eggs, being semibuoyart and nonadhesive, and a thirty-five pound fish has yielded 265,000 ripe eggs. Spawning takes place in May, in shallow, grassy places. The eggs are about 1-11 of an inch in diameter and number 74,000 to the quart. About 97 per cent of the eggs impregnated are hatched. With the water temperature at 55 degrees $\mathrm{F}$., hatching ensues in 15 days, the yolk sac being absorbed in the same time. The fry are very helpless when first hatched.

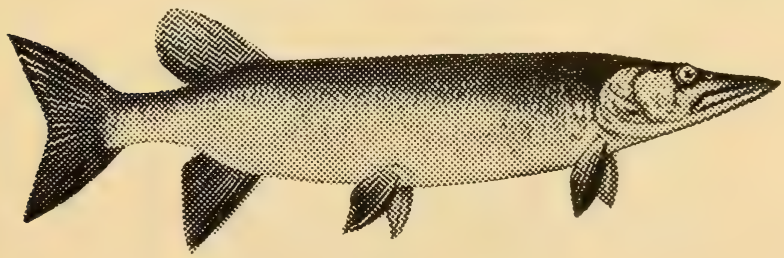

UNSPOTTED MUSCALLONGE.

Caught in Wisconsin Waters.

T'his is a fish native to the waters of Wisconsin and Michigan and is found in many lakes It grows to thirty or forty pounds in weight, and in habits resembles the spotted muscallonge, which, even in Wisconsin, are more numerous. It is a good table fish, but is hard to catch, being shy and a great fighter when hooked. 


\section{MUSCALLONGE FISHING.}

Fishing for muscallonge compared to other fishing is about as different as shooting prairie chickens is compared to deer shooting. In trout fishing the angler expects to hook a fish frequently or he moves on down the stream for a better place. In fishing for muscallonge it must be done by trolling. A boatman is necessary and he must be a good one, for the boat must be kept moving at a good speed. The rod should be short, three to five feet, with spring enough to hold the fish and set the hook without breaking the line. The writer has some notions which differ from many muscallonge fishers. He uses the same rod and line that he uses for bass and generally uses a strong quadruple reel, though many use a much larger reel and a larger line, and they believe they must have such an outfit.

The lure generally in use is the number nine Skinner spoon hook, though a larger size is favored by some. A number seven spoon hook is just as sure to hook and hold the muskie. Another lure is the wooden minnow six inches long, sufficiently weighted to keep it three to six feet beneath the suriace. Eighty to one hundred feet of line should be played out and the boatman should then locate a bunch of reeds, sunken logs, or "dead head" logs, and continually circle around these, for it is in such places that the muskies will be found.

When a strike is had, hold a firm grip on the rod, throwing the point upwards and reeling in at every slack of the line. Should the muskie make a rush away from the boat let him have the line, keeping it taut. He will jump out of the water and attempt to throw the hook from his mouth. With a taut line this is quite impossible; but should he rush toward the boat, and jump before the line can be reeled in he will throw the hook twice out of three times, and it is very essential that the slack should be taken up at once as fast as the line can be reeled in. The fish, being well hooked, will soon tire and with spasmodic plunges, will be brought along side the boat. Here the best methor is to shoot him through the head with a pistol. Then he can be lifted into the boat with gaff or net. An automatic gaff is very handy in landing these fish if no pistol is at hand. Muscallonge range from eight to sixty pounds in weight. 


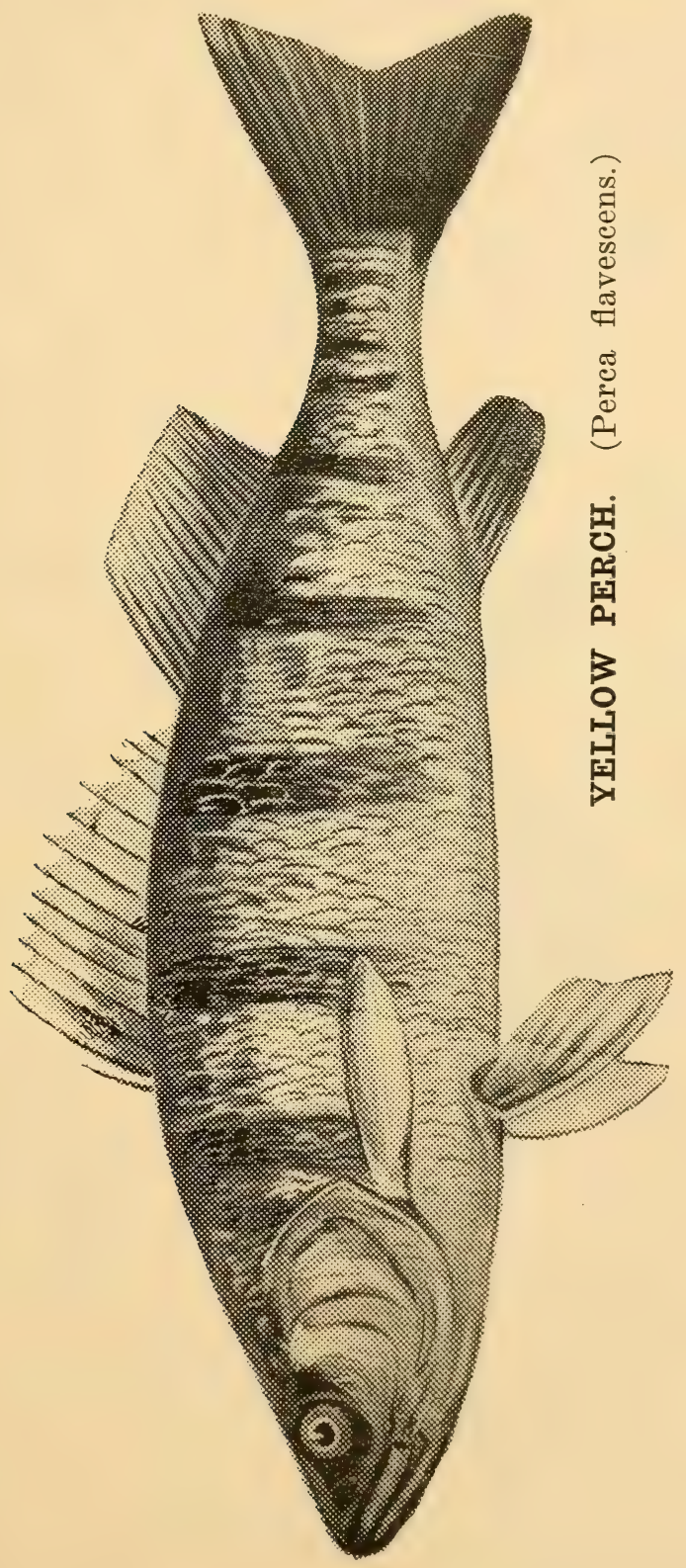




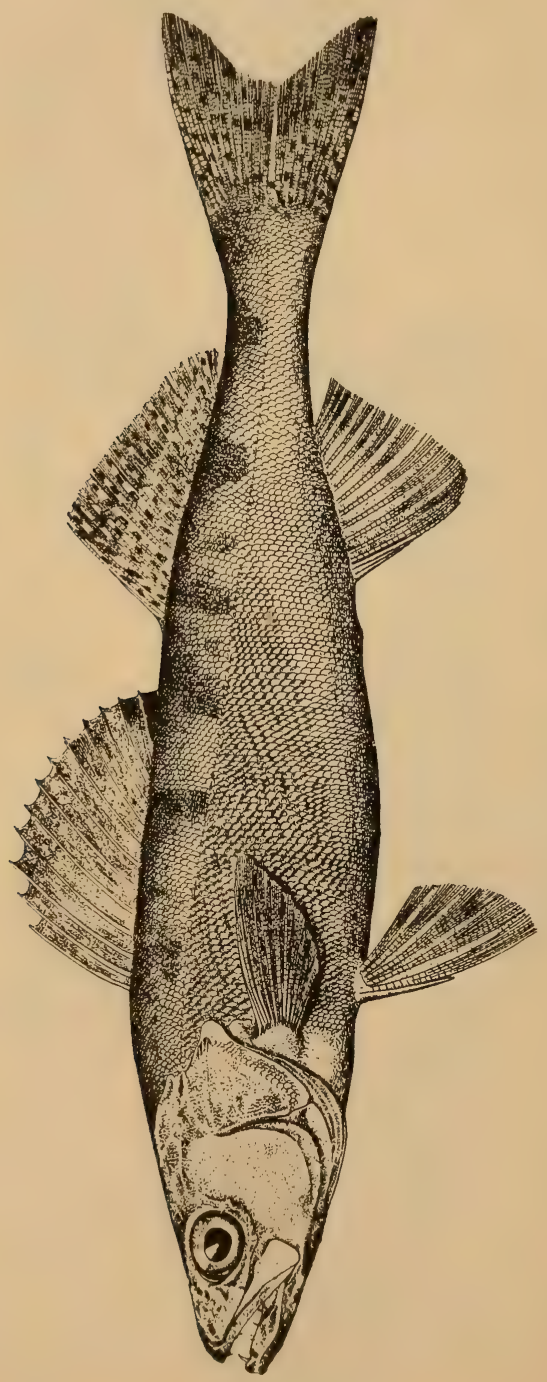

ह

독

ค

더

되

H

$B$

㖕 


\section{YELLOW PERCH.}

(Perca flavescens.)

This is one of the most desirable food fishes found in Western waters, and by many is considered superior to black bass or the pike perch (wall-eyed pike). It grows to two pounds in weight, and rises well to almost any kind of bait.

\section{PIKE PERCH-Walleyed Pike.}

(Stizostedion vitreum.)

The Pike Perch, commonly called "Wall Eyed Pike," is generally regarded as the best of food fishes found in the western 'waters. Its flesh is fine grained and of sweet flavor. Its bones are large and it may be served in various ways with equal relish.

Ordinarily the Pike Perch are found in deep cool water and are most successfully taken in trolling early in the morning or late in the afternoon or evening. Their average weigh $i$ is about two and one-half pounds, though they have been caught weighing as high as 22 pounds.

The best all round bait for these fish is the frog, golden shiner, or crawfish, though they will sometimes bite a shrimp. They do not respond readily to the artificial lure. They are not game fish. The same tackle that is used for bass is best for Pike Perch fishing.

\section{SAND PIKE-Jack Salmon.}

This is a fish common to the Mississippi river, and which belongs to the perch family. It is inferior to the Yellow or Ringed Perch or the Pike Perch (Wall Eyed Pike), for the table, though it is by no means to be discarded. 


\section{THE SCALED OR ASIATIC CARP.}

This is the scaled carp found generally in all waters of the West.

Considerable discussion is now in progress in the West over proposed legislation to destroy this fish, or, at least, restrict its propagation to certain waters, to prevent it destroying game fish and other more edible and desirable food fish.

The carp is a soft fish, and will not keep long unless bled and drawn and immersed in cold water until cooled. The fisi may then be kept on ice for a week or two. If handled in the usual way, they are scarcely fit to eat on the following day unless caught in the winter and frozen. They are a third rate food fish, though by some they are considered good.

The fish and game commission of California and others who have studied the carp planted there claim that these fish destroy the celery and all other vegetation upon which wild ducks feed, and that the ducks do not now frequent the lakes.

These fish subsist on roots and animal life, and destroy the vegetation by burrowing in the bottom and sides of streams and lakes, often digging holes ten to fifteen inches in depth. In doing this they roil the water and break up the spawning beds of bass, pike, perch and other and better fish.

Carp were first imported into this country when a resident of California, in 1872, brought five fish from Holstein, Gelmany, and put them into a private pond on his farm. In 1877 the California game and fish commission imported eight young carp from Japan, they being of the same variety as those from Germany. This was the beginning of the experience with carp in this country. In California, Oregon and parts of Washington they swarm in the irrigation ditches, swamps, lakes and rivers, and even in the water works reservoir of Sacramento, where for years four men, with seines, and twelve sea lions, were employed to get rid of the fish. This was done and black bass were substituted.

Carp were first introduced into Germany from Asia. There are several varieties, all coming from the far Eastthe Asiatic, scaled carp, the leather carp (German), the tench, the goldfish and others.

The only time to catch the carp is during one hour at sunrise and one hour at sunset. Use a very small hook, baited 
b

with a worm. The line shouid ve uasn-cuivied and have no gut leader. Attach a small cork float to the line six inches above the hook. Cast your hook a few feet from shore, and then throw small pieces of bread into the water. After five or ten minutes the carp will take the bread and the worm on your hook as well. Give the fish plenty of time to suck in your bait. After the float has remained under water one or two minutes haul in your fish. He will hardly struggle until you have him in the basket, but there he will flop around for three hours. Do not try to catch carp after a heavy rain, as they will not bite then.

\section{MIRROR—or King Carp.}

(Cyprinus carpio specularis.)

The Mirror or King Carp has unusually large scales irregularly placed in short rows on its body. It is a peculiar looking fish and will readily be aistinguished from other varieties-the Asiatic or scaled carp and the leather carp, the latter having very few scales or none at all. Reference to the habitat of the Asiatic Carp and the methods for catching this fish also apply to the Mirror or King Carp.

The Carp family is very extensive, embracing forty varieties and about two hundred and fifty species in the United States alone.

\section{THE TENCH. (Tinca tinca.)}

The Tench is a fish of the Carp family. It came from Europe and has been extensively planted in this country. It reaches the weight of ten pounds and is found in the Mississippi river, having come up this stream from Illinois rivers, where the Tench was extensively planted years ago. In the irrigation ditches of Montana, Idaho and Colorado, this and other varieties of Carp have been planted. It is considered the most edible of all the Carp fishes. 


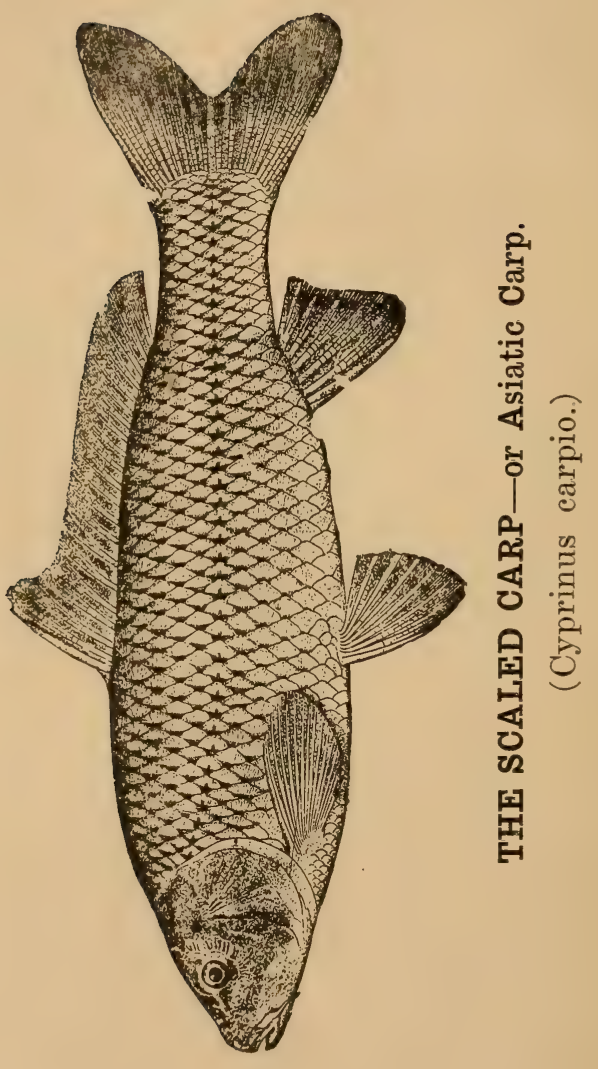




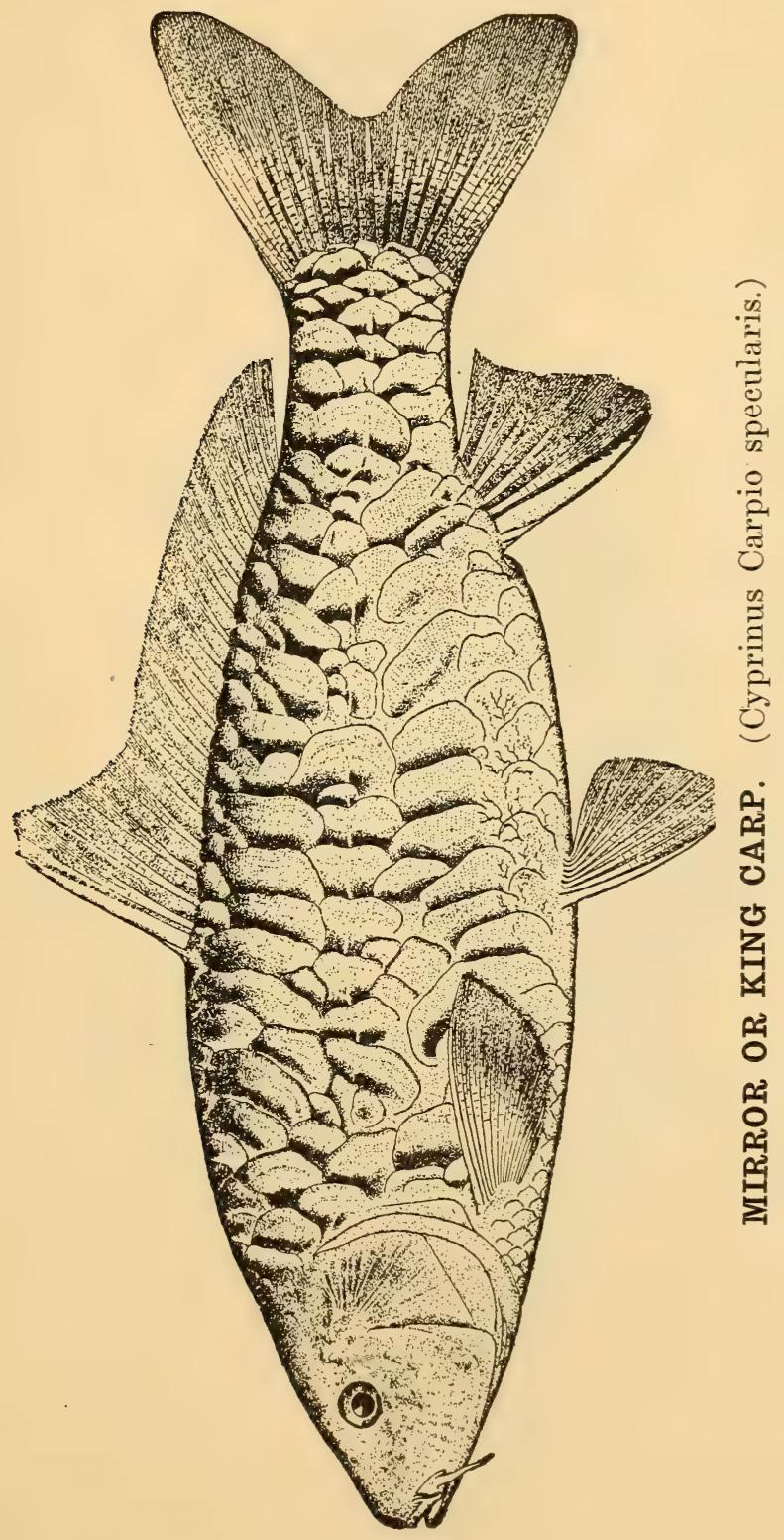




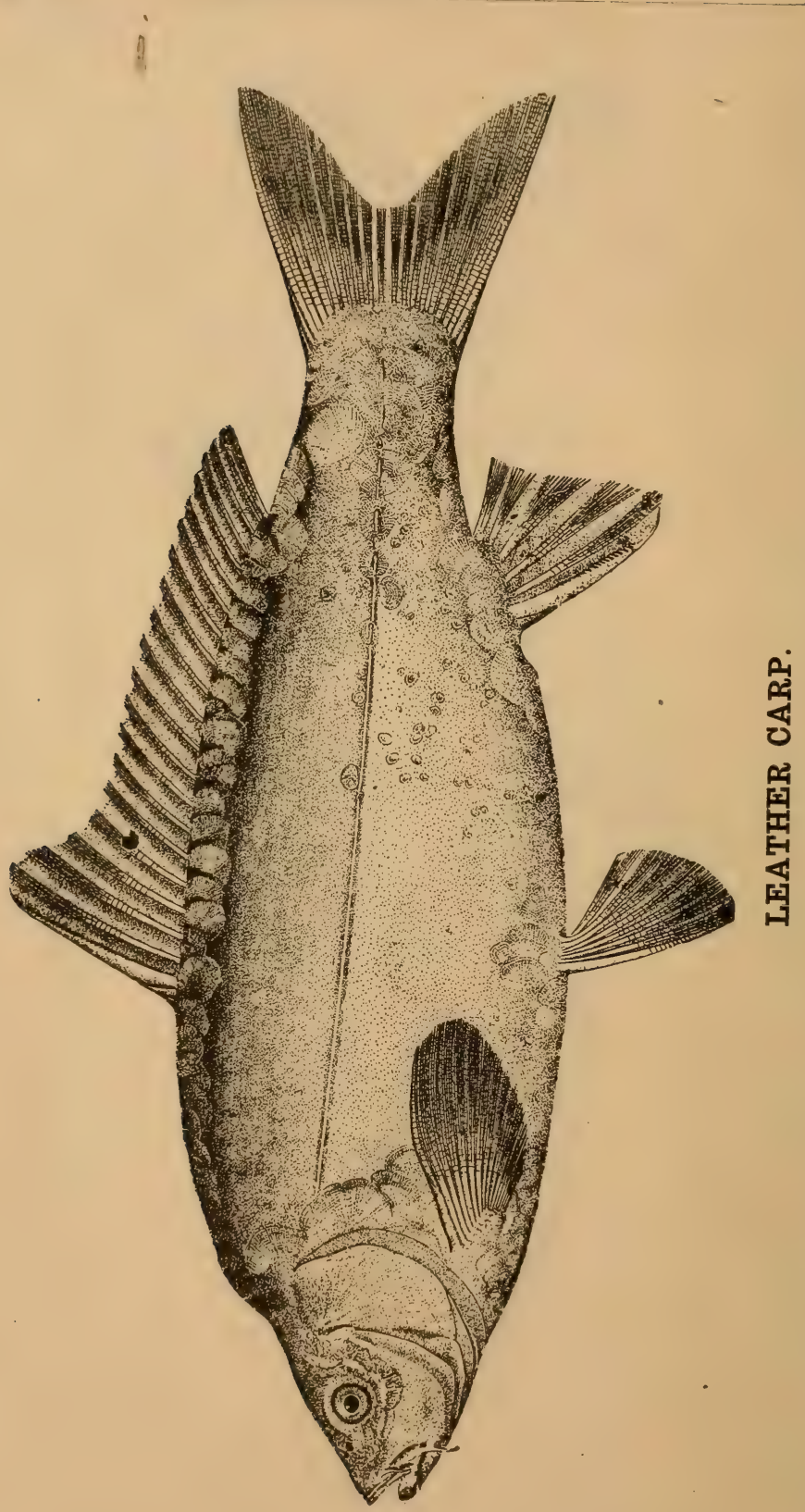




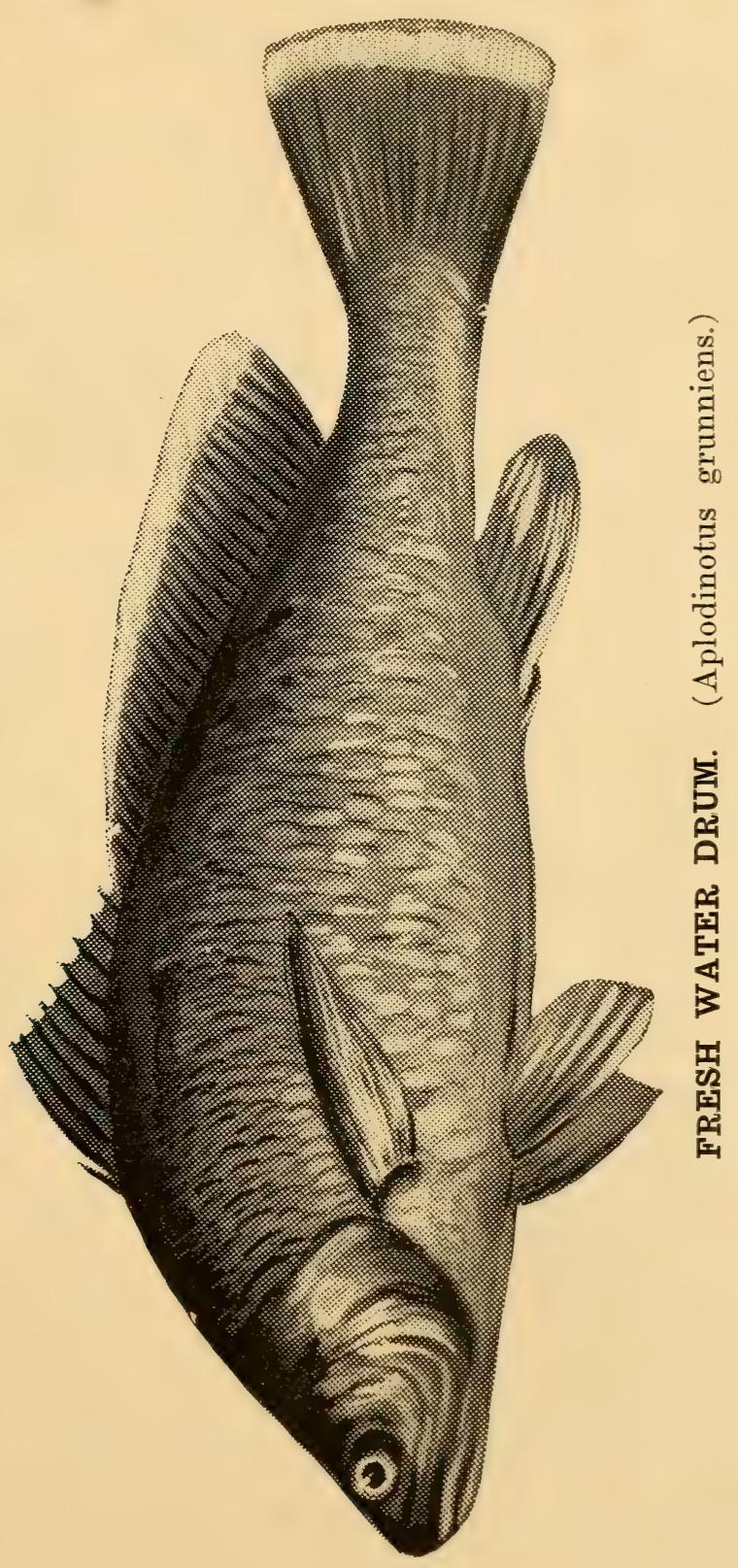




\section{THE WHITE FISHES.}

While the common whitefish is the only member of the tribe that has received much attention from fish-culturists, it is probable that several other species of whitefish will in time be extensively propagated. The lake herring(Argyrosomus artedi) has already been artificially hatched to a limited extent at Put-in Bay station, and the long-jaw or bloater (Argyrosomus prognathus), the bluefin or blackfin (A. nigripinnis), the tullibee (A. tullibee), and others will doubtless become the subjects of fish-cultural work in certain lakes. The eggs of all these fish can be hatched by the same methods as are used with the common whitefish, but the spawning seasons differ.

The lake herring is readily distinguished from the common whitefish by its smaller size, projecting lower jaw, long and numerous gillrakers, absence of arch on back, etc. It is the most abundant of the whitefishes, being especially numerous in Lakes Erie, Michigan, and Huron, and larger quantities are taken each year than of all other species combined. The average length is 12 to 14 inches and the average weight is under a pound, although a maximum weight of 3 or 4 pounds is attained. The fish is generally known as "herring" but has numerous other names, among which are cisco, blueback herring, greenback herring, grayback herring, and Michigan herring.

The spawning season of the lake herring begins somewhat later and terminates sooner than that of the whitefish. The egg are procured and hatched in the same manner as are those of c. clupeformis, and require about the same time for incubation, namely, 4 to 5 months, depending on the temperature of the water. The eggs are smaller than those of the common whitefish, 70,000 making a fluid quart.

These two species are readily hybridized artificially. The milt of either species will impregnate the eggs of the other as effectively as if there were no cross fertilization. Large specimens of apparently hybrid fish of this character have been obtained in Lake Erie. The use of milt of the lake herring for impregnating whitefish eggs is resorted to only when the eggs would otherwise be lost.

The round whitefish or menominee (Coregonus quadrilateralis) is propagated by the New York Fish Commission. It is very widely distributed, ranging from New Brunswick to Alaska, and is abundant in some of the Adirondack lakes, 
where its eggs are taken and hatched in comparatively large numbers. It rarely exceeds a pound in weight, but its food qualities are good, and it is taken for market in considerable quantities in Lakes Huron and Michigan.

In the New York lakes, where the fish is known as the frostfish, the spawning season is from the middle of November to the early part of January, although the period in any one lake is less prolonged. The eggs are heavy, adhesive, and 1-8 inch in diameter; the average yield per fish is 3,500 , but 12,000 have been taken from a $13 / 4$-pound fish. In the very cold water of these lakes the incubation is protracted, being 150 days with the water at 33 degrees $F$. The sac is absorbed in 10 to 20 days.

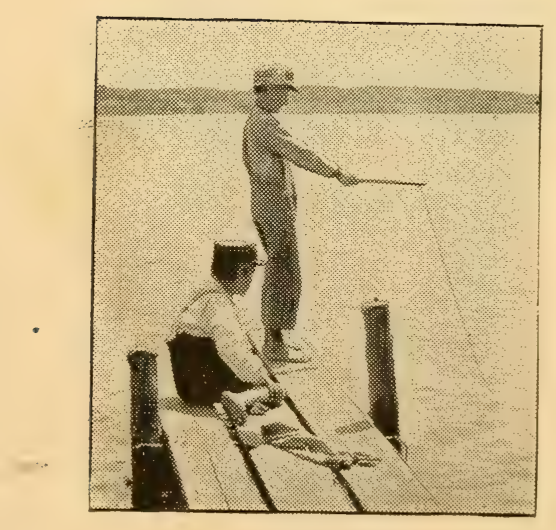




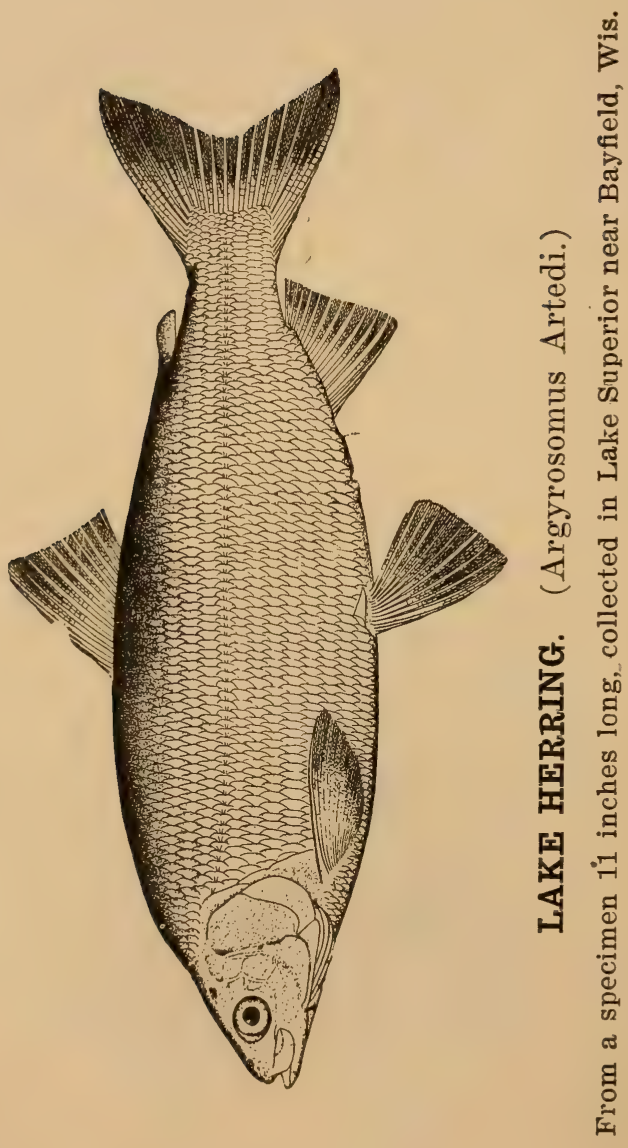




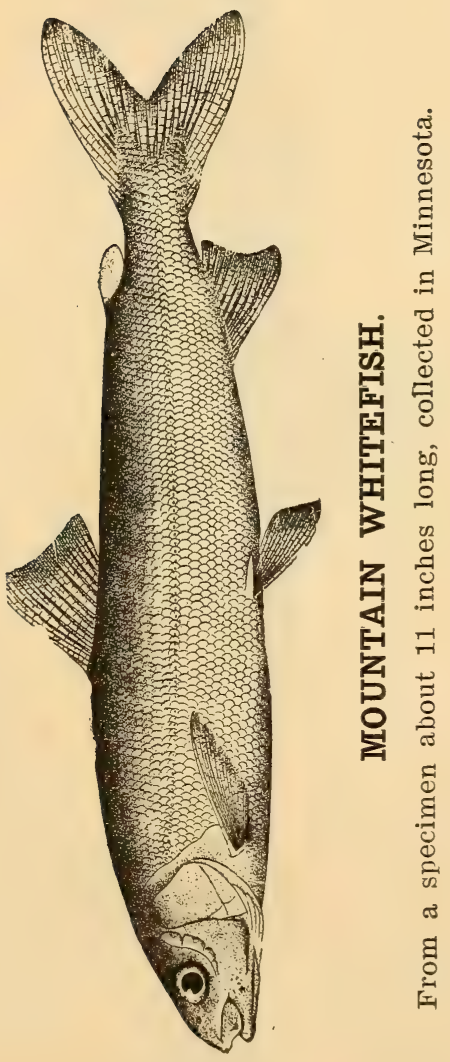




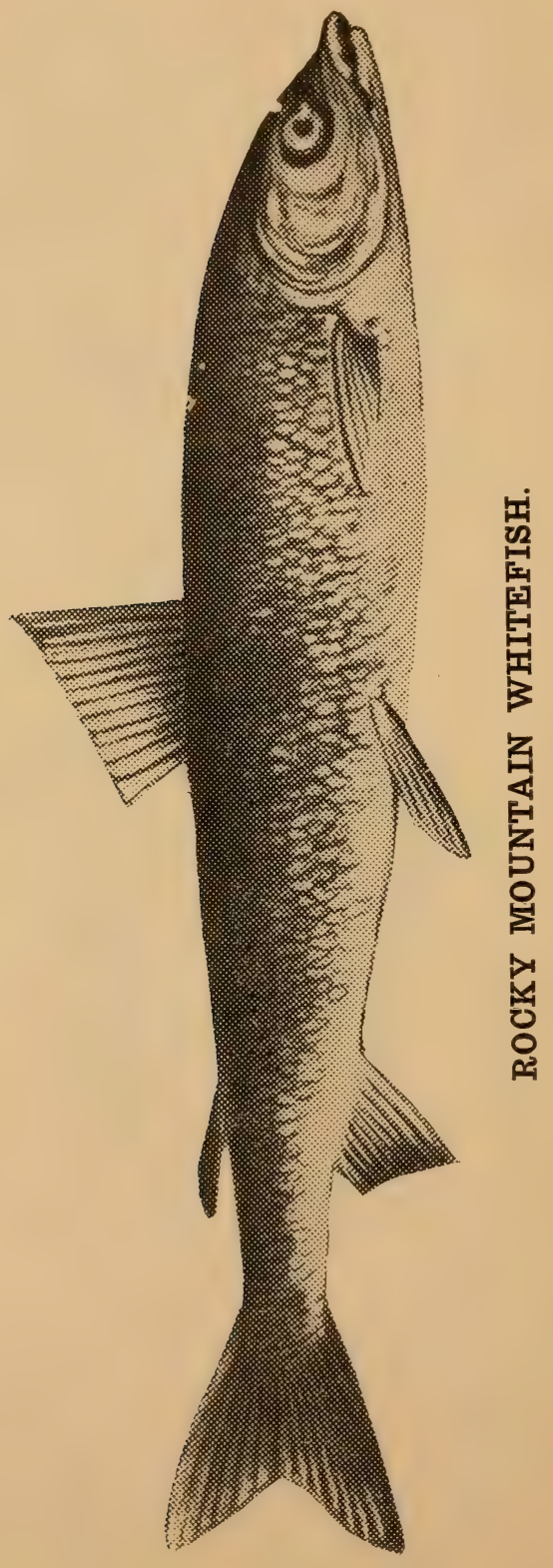




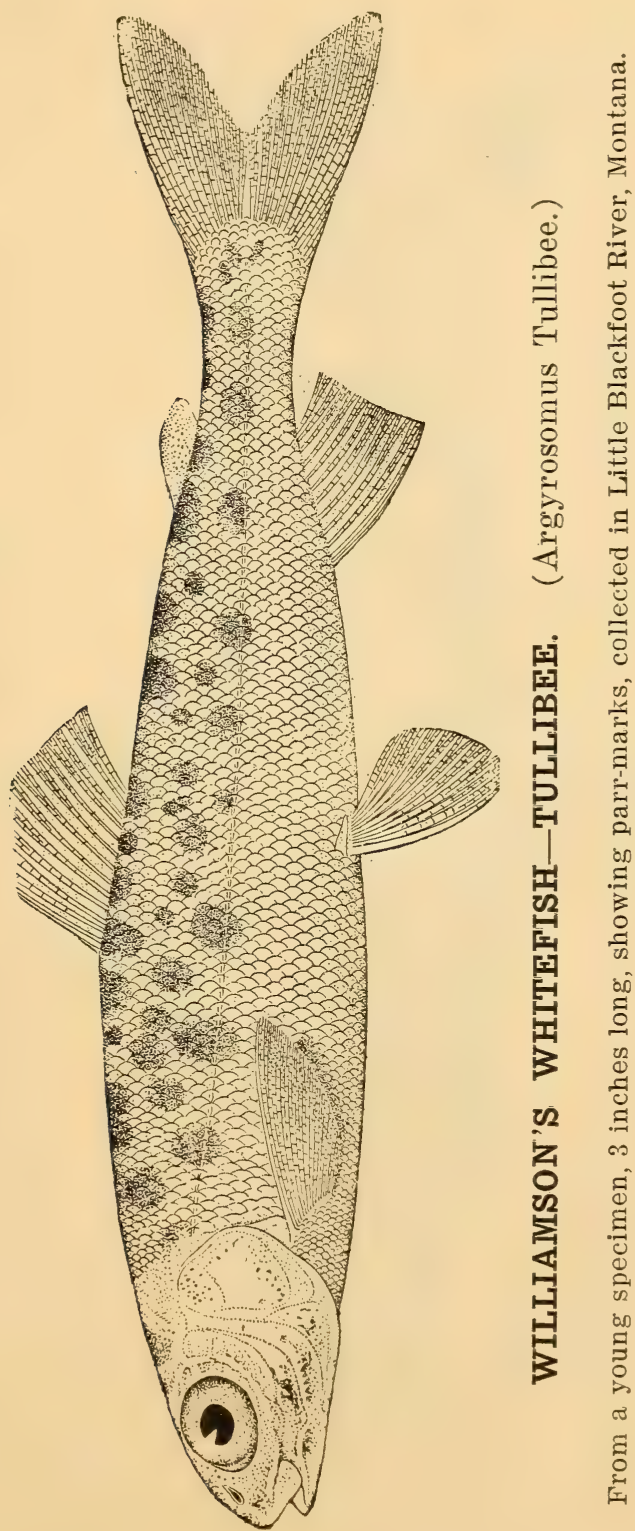




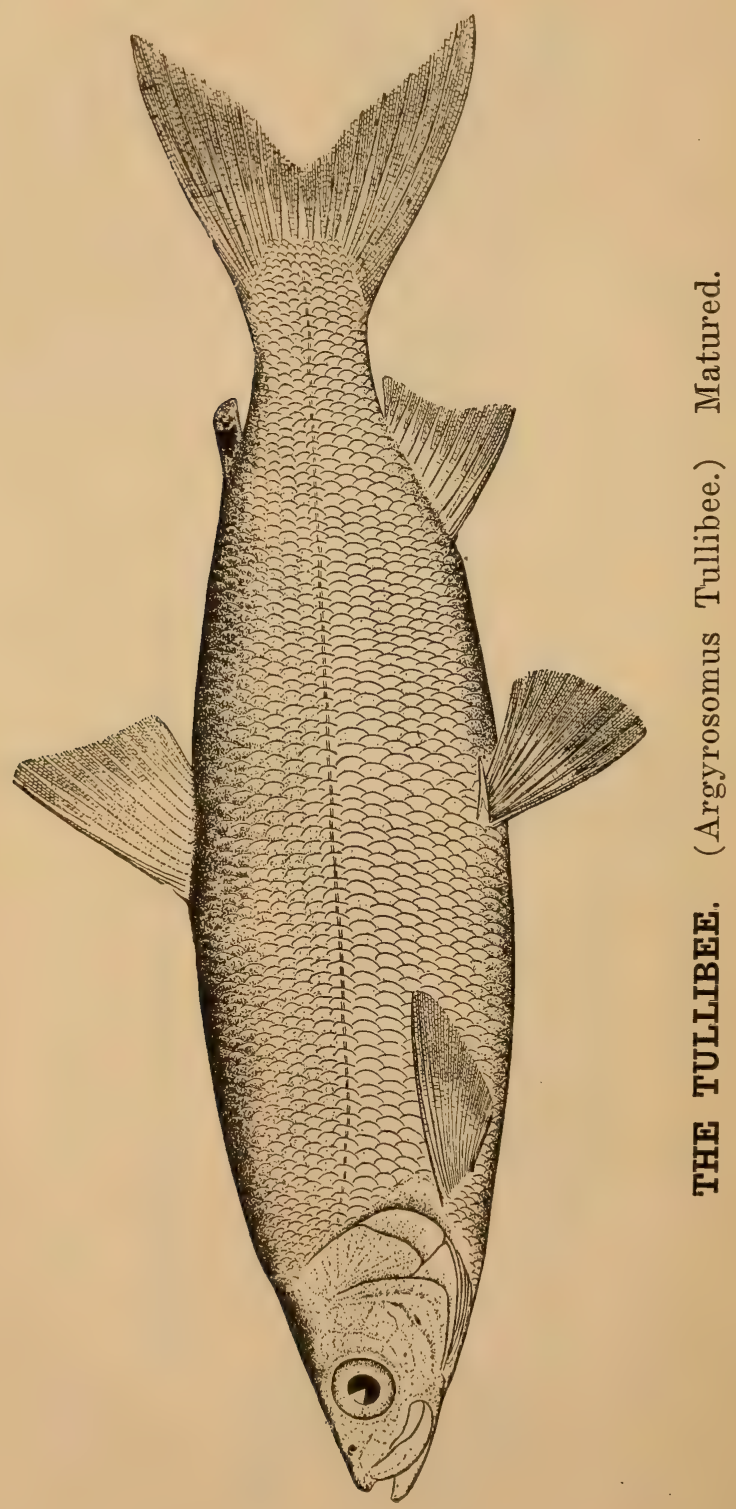




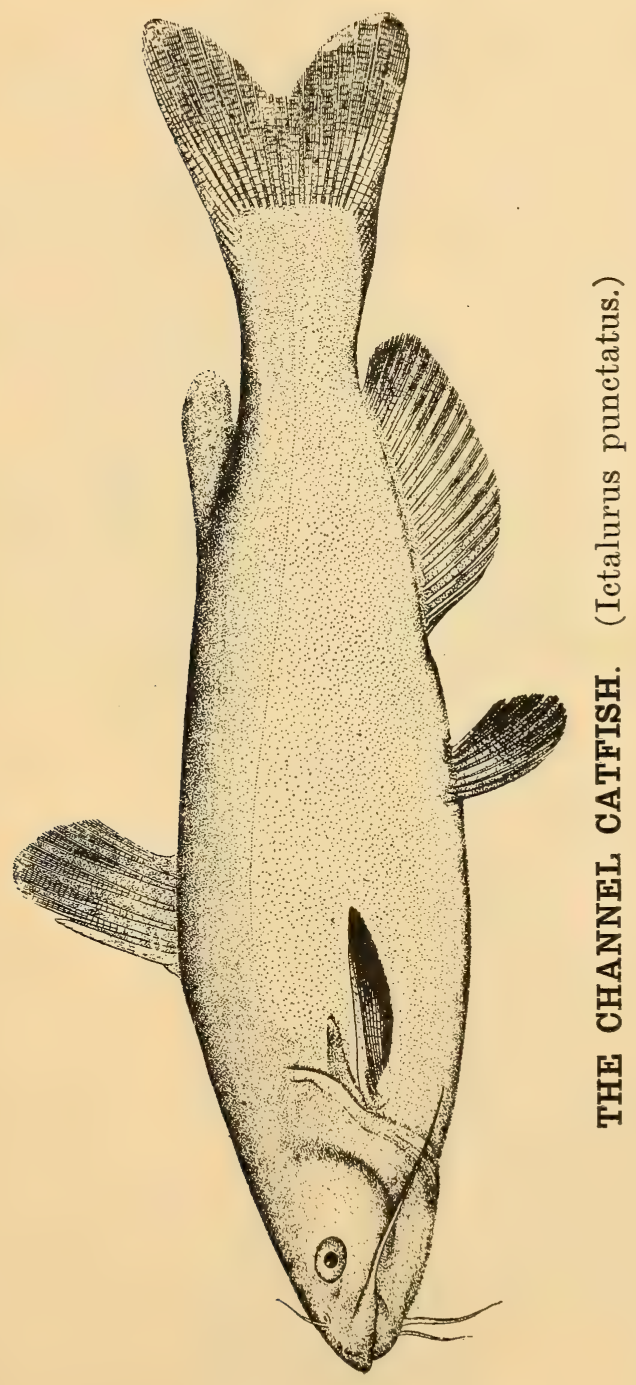




\section{THE CHANNEL CATFISH. (Ictalurus punctatus.)}

There are seventeen varieties of catfish listed by the government but there are probably not more than three or four varieties in the west except those which find their way up the Mississippi or Missouri rivers.

The channel catfish is extreinely shy and is rarely caught in daytime, and then only in deep water, except during spring freshets. When the water is roily enough to be almost liquid mud, allowing so little light to penetrate the water that all minnows and most scale fishes hunt the shallow water near shore, the channel cats may be found foraging in the deep water of the swiftest and most turbulent portions of the channel.

Dark summer nights are the best to catch channel catfish, and the darker the better. Between midnight and daybreak of very dark nights, especially if a heavy fog has settled low on the water, the fisherman, slipping along quietly in his boat will hear the hoarse bellowing of the bullfrog, the plaintive cry of the whip-poor-will, and occasionally a splash as if an old cow had fallen into the river. The splash is made by a large catfish chasing minnows into very shallow water. 


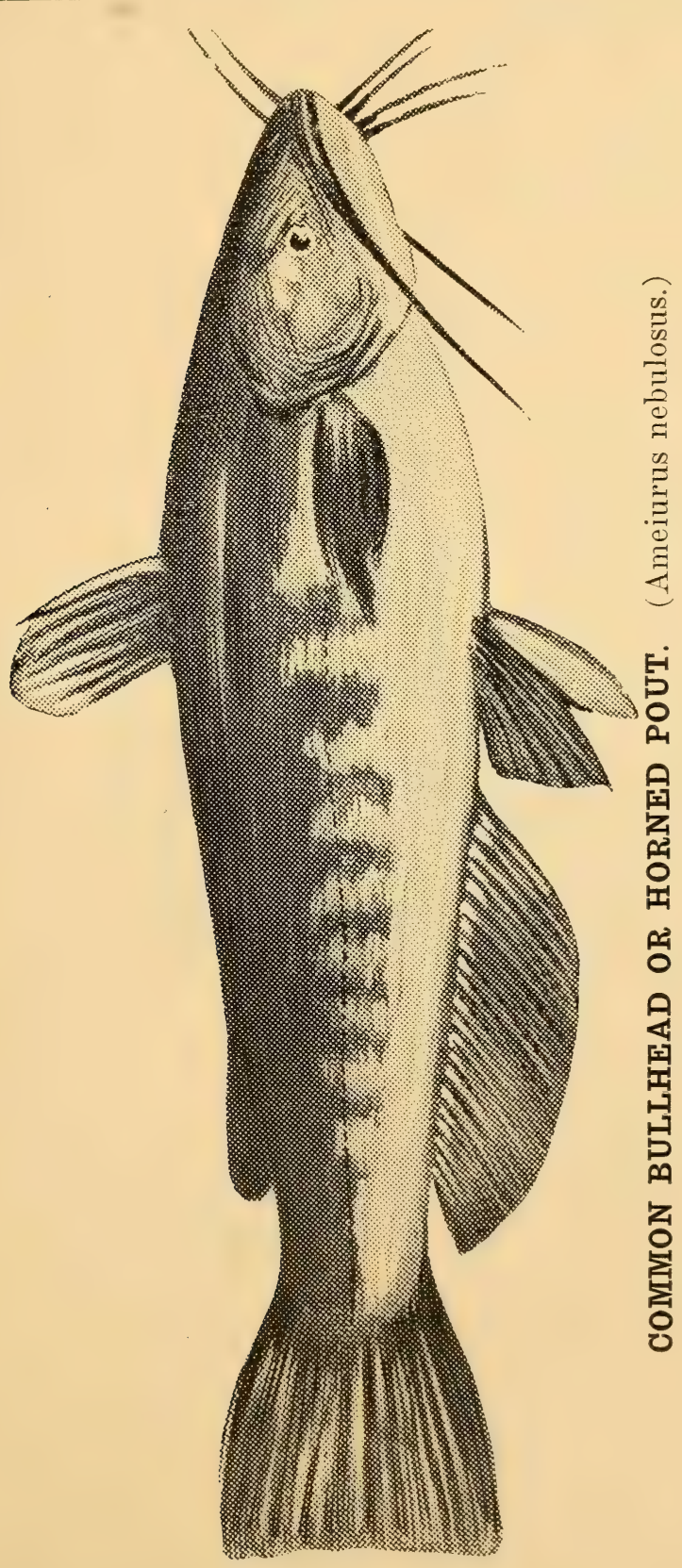




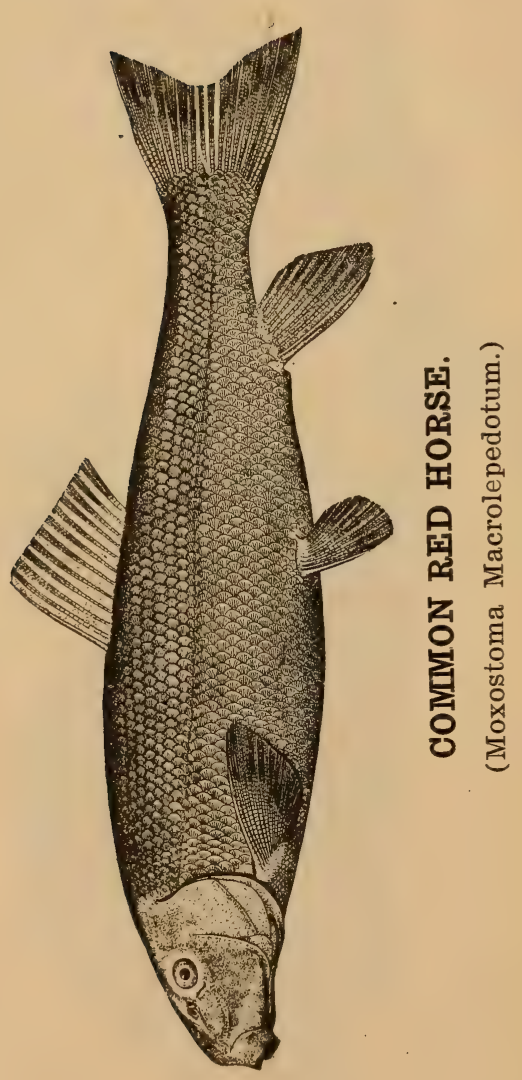




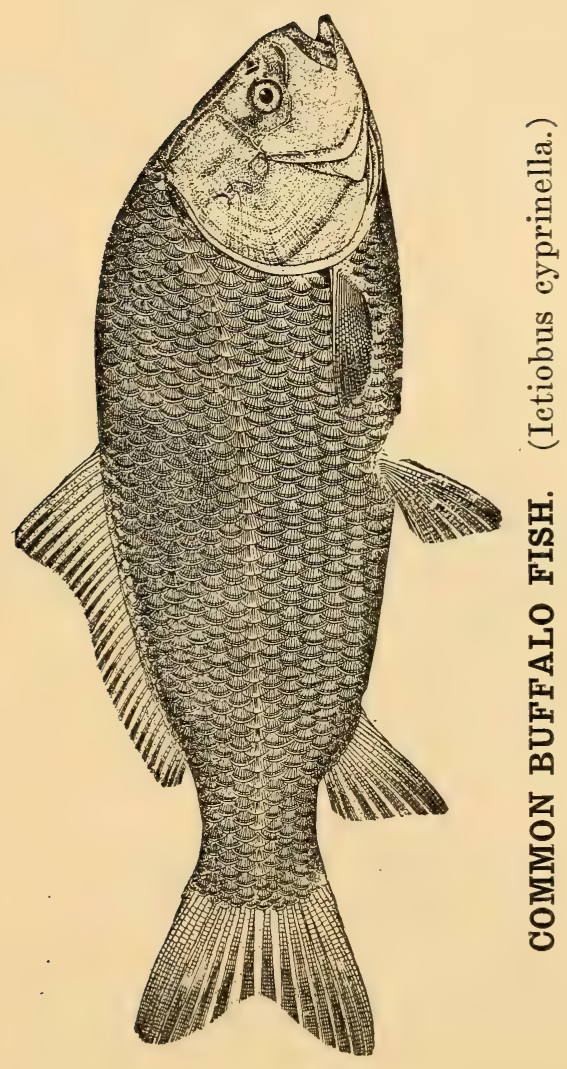




\section{BULLHEAD, or Horned Pout.}

\section{(Ameiutus nebulosus.)}

The bullhead is of the family of catfishes. Its breeding powers are tremendous, and it is said that a single fish will produce a half million young. It grows from six to twenty inches in length. It will take almost any kind of bait, worms preferred. The usual method of dressing these fish is to skin them. Unlike most other fish they are full blooded and when dressed have the appearance of raw beef. They are sweet and are regarded by many as superior to most fish for the table. They are senerally found in sluggish streams.

\section{RED HORSE.}

\section{(Moxostoma Macrolepedotum.)}

The Red Horse of Northern waters, mostly found in the rivars and creeks, belongs to the sucker family. Indeed, there are so many suckers which are known by other names that it is difficult for the aligier to correctly classify them.

The Common Red Horse grows to eighteen or twenty inches in length. The rays of the dorsal fin are thirteen or fifteen. The fish is of red bionze color, and when young is sometimes known as the golden snciker. It may be caught in the same manner as sucisers, with hook and line, red angle worms, dough or hon€y halls or rije cherries being successful lures. The bait nust be kept near the bottom perfectly quiet. To malic a noisn is fatal to this class of fishing.

\section{BUFFALO FISH.}

\section{(Ictiobus cyprinella.)}

The Buffalo fish is also a species of the sucker family. They are found in the large rivers of the west and do not attract the attention of the angler. They bite hard and fight hard, though not gamey. They often grow to weigh twenty pounds though those of three or five pounds are most often seen. They suck their food, though they are able, with larger mouths, to take much larger bait than the common sucker. There are several species of buffalo fish, which derives its name from the peculiar hump on the anterior portion of its back, like that of a buffalo. 


\section{NORTHERN SUCKER.}

Several varieties of suckers are found in the western lakes and streams, but generally they are not taken with hook and line, although this may be done. These fish are frequently speared but as there is little sale for them, except among the poorer classes, they are not often disturbed. The sucker is most desirable when it is three inches in length. At this size it makes splendid bait for pike and bass, and when six inches in length is a sure attraction for muscallonge. When small the suckers are almost pure white, which accounts for their attractiveness. As they grow larger they become darker on the back.

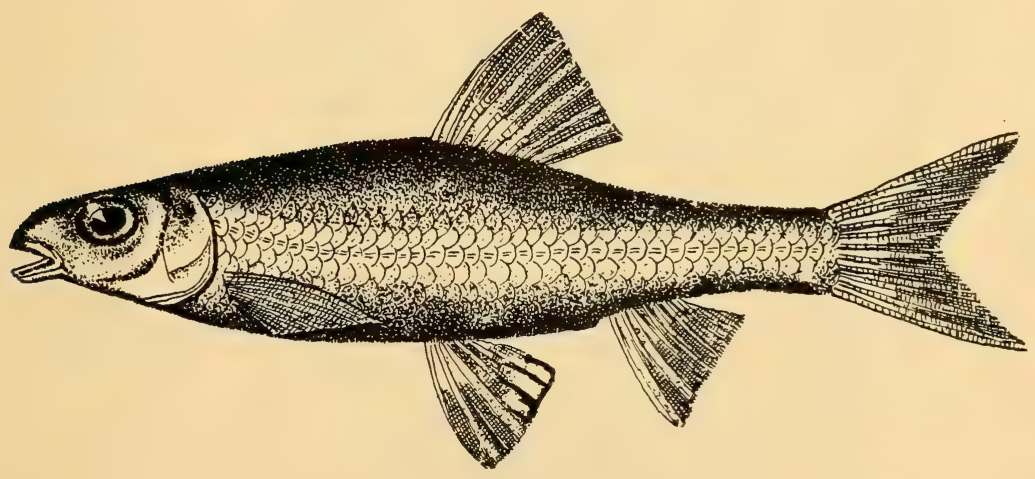

The Smelt or Gudgeon.-Notropis hudsonius amarus.

The spawn eater or smelt (Notropis hudsonius) is one of the chubs taken by the angler on black bass and trout streams. It grows to about ten inches in Lake Erie and other large waters and ranges from Western Minnesota east to New York. It is abundant in the Great Lakes, and in the streams of Minnesota and Wisconsin. The coloration is pale with, usually, a round black spot at base of caudal fin, which is always present in the young. There is also a broad lateral silvery band which in some waters becomes dusky. It is said to be a good table fish and is a choice lure for the black bass, the pike and the muscallonge, for which purpose it is used extensively by anglers. 


\section{SHEEPHEAD. (Archosargus Probatocephalus.)}

The sheephead is similar to the carp, though it has not so been classified by the United States Fisheries Commission. The sheephead is found in the Mississippi river as far north as its source, in the Missouri river as far north as Omaha and in most southern streams. It is something of a sucker, and really belongs to the sucker family. It has a small mouth and will suck in any small bait such as dough, angle worms, berries, or small pieces of liver or fried meat. It is a fairly good table fish if cooked at once.

\section{THE ROACH-or Golden Shiner.}

The roach, or golden shiner, is known too as the "boys" fish. It is found in all streams, and is more noticeable in small shallow sandy bottom creeks. It is the fish we hooked with a pin when we first began angling. It is caught in nets and sold mostly for bass and pike perch bait, and is believed to have no equal as a lure. Its color is olive green with a silvery band along its sides, while the scales sparkle and glisten in the sunlight like tinsel, attracting fish for a long distance. It grows to eight or nine inches in length, but is more desirable for bait when about three inches long. During the fall and winter months the roach makes an excellent pan fish when cooked in the same manner as trout.

\section{THE COIMIMON CHUB-or Fall-Fish.}

The common chub, or fall-fish, is found east of the Missouri river. It seldom grows more than a foot in length, and is the species most frequently met with by trout fishermen, and it is upon its presence or absence in a trout stream that anglers predicate the continued fruitfulness of such waters. Wherever it gets a foothold in the smaller streams, it means good-bye to the trout, owing to the fondness of the chub for the spawn and young fry or brook trout. But compensatory nature gives the angler consolation in that whatever stream the black bass lives and thrives, it means destruction to the chub for which the bronzebacker has an excessive hungering. 


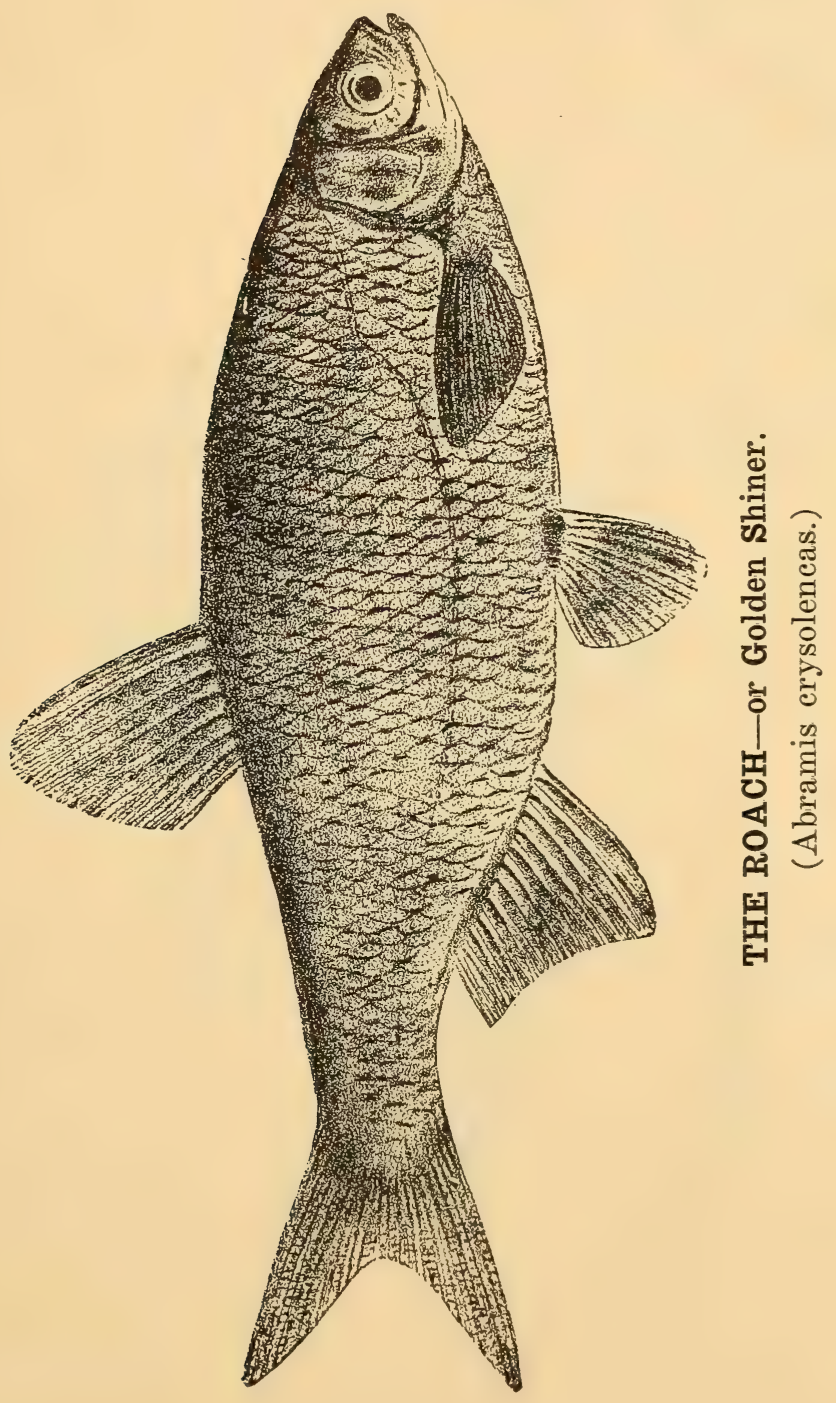




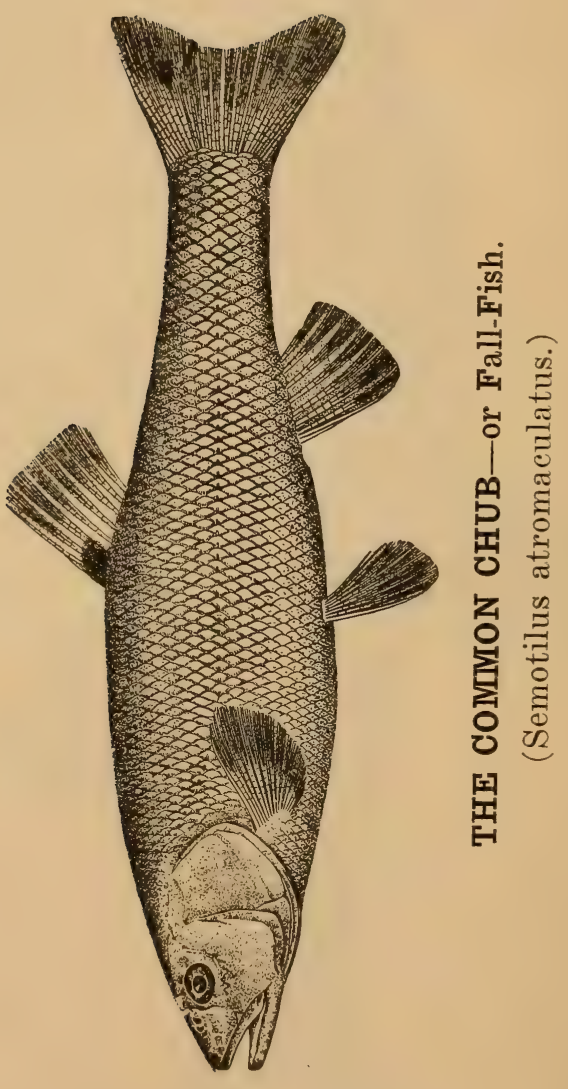




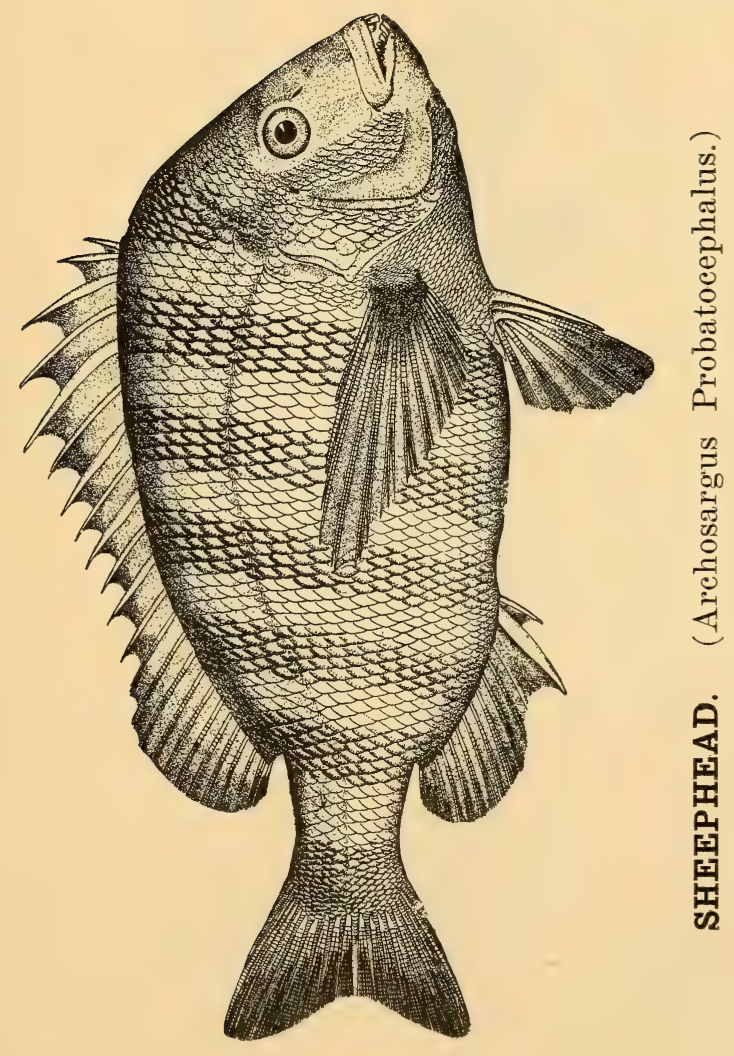




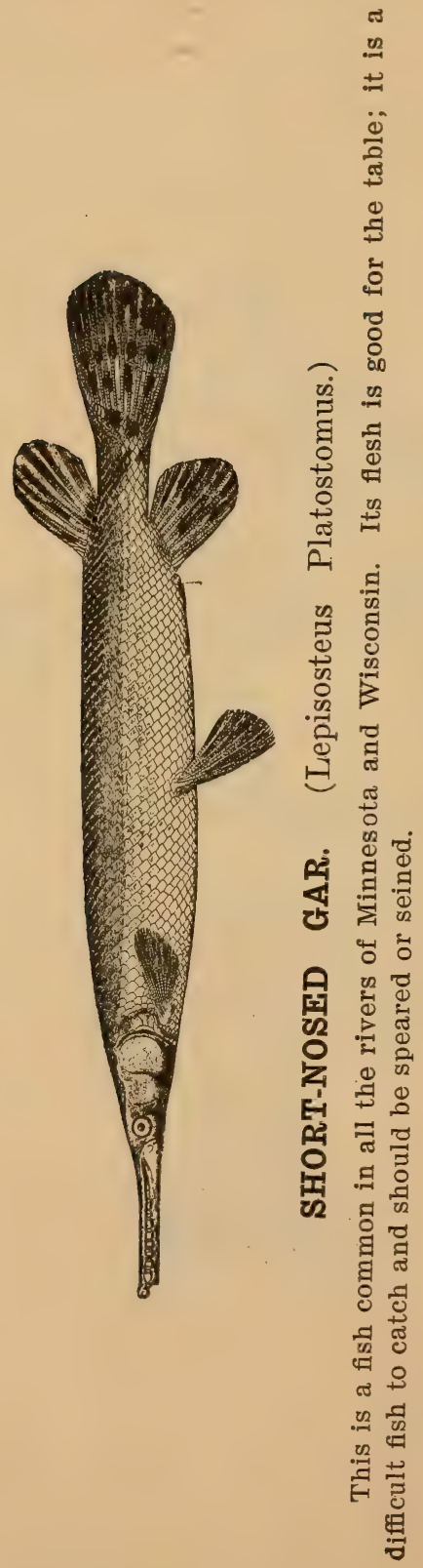




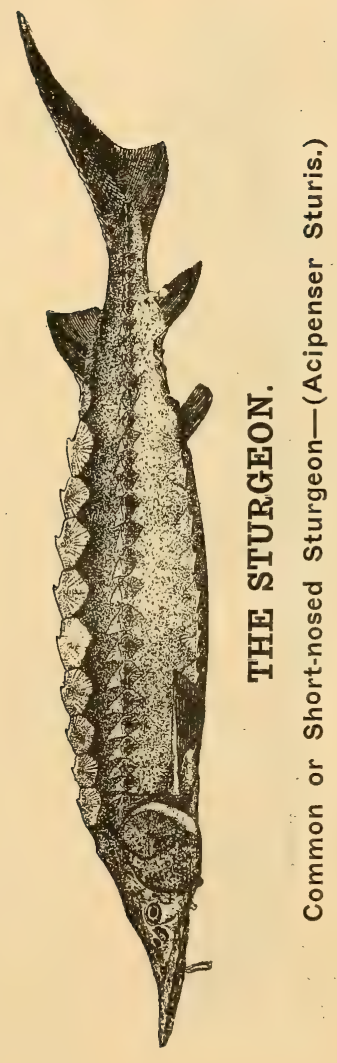





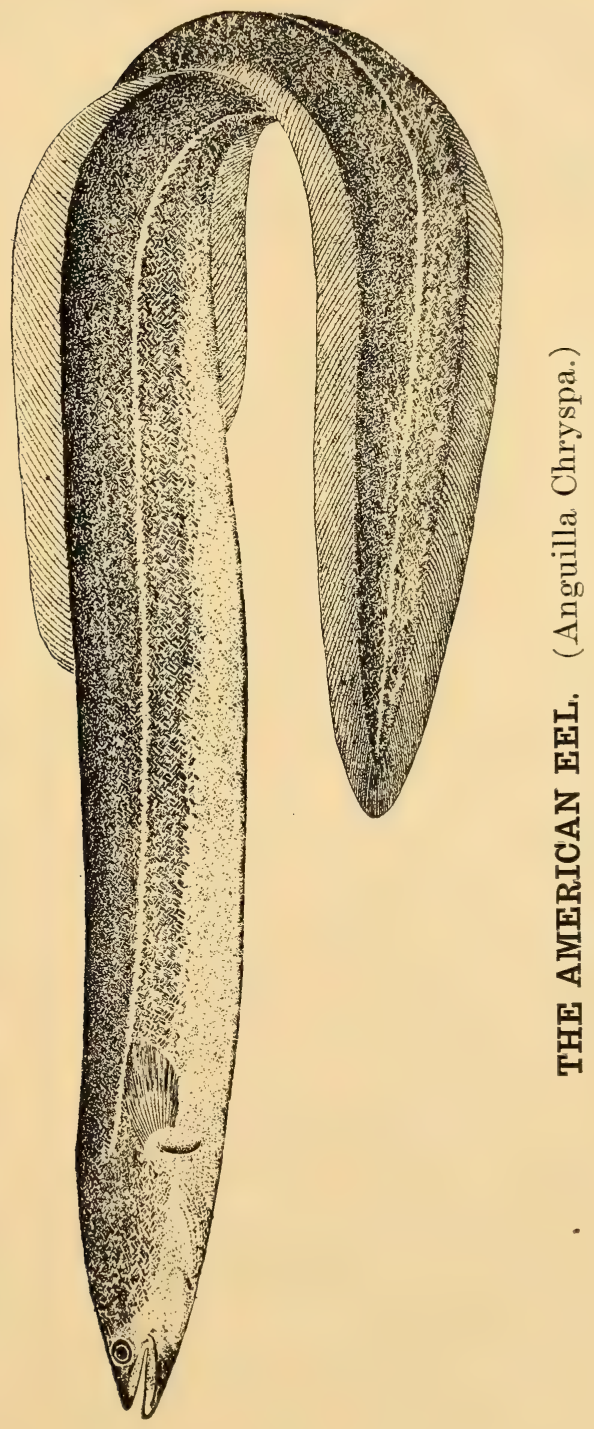




\section{THE STURGEON.}

\section{(Acipenser Sturis.)}

There are six species of sturgeon in the waters of the United States. The common and the short-nosed sturgeons (Acipenser sturis) and (A. brevirostris) are found only on the Atlantic Coast, ascending rivers to spawn. The white sturgeon and green sturgeon (A. transmontanus) and (A. medirostris) inhabit only the waters of the Pacific Coast. The lake sturgeon or rock sturgeon (A. rubicundus) exists in the Great Lakes, the Upper Mississippi Valley, and other northern interior waters. The shovel-nose sturgeon or white sturgeon (Scaphirhynchus platyrhynchus) is found in the Mississippi and other streams of the Southern and Western States.

While all of the sturgeons are edible and caught for market, the most valuable species are the common sturgeon and the lake sturgeon, 'which alone have been artificially propagated.

\section{DOG FISH.}

\section{(Amia Calva.)}

This fish is mentioned because of the necessity that exists for its extinction and acquainting amateurs with its dangerous characteristics. It is a fish that one might eat when hunger threatened starvation. In many of the waters of the west the angler will frequently hook a dogfish when casting or trolling for bass, and must land and kill it to recover his hook. An automatic gaff is convenient for taking these fish from the water. The gaff will hold the fish firmly until the hook is removed and until the cord just back of the head has been severed, and danger from its sharp teeth are passed.

These fish are great destroyers of other fish and of spawning beds of the food and game fishes.

\section{AIMERICAN EEL.}

\section{(Anguilla Chryspa.)}

Eels are frequently caught in the rivers of the west. Occasionally one is taken with hook and line, but more frequently they are brought to the surface while seining. They live and get their living in the mud. The United States Fish Commission reports "planting" several hundred Eels in a 'western lake, in about one foot of water. Within ten minutes say the commissioners every eel had bored into the mud at the bottom of the lake and disappeared. The eel is regarded as very destructive to the spawn of other fish, and it is well that they are not more numerous in our lakes and streams. 


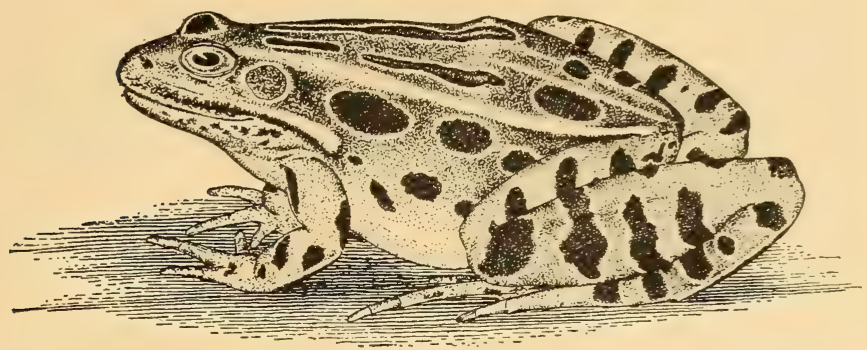

FROG.

Spring Frog or Leopard Frog (Rana virescens).

In taking frogs for market, lines baited with red cloth, worms, or insects are extensively used; guns, small-bore rifles, and spears are also employed, and cross-bows are adopted for this purpose in Canada. They are often hunted at night, a lantern furnishing light for the hunter's aim, and at the same time blinding or dazing the frogs. The peculiarly formed tongue-loose behind, so that it may be thrown out to quite a distance-is covered with a viscid secretion so that the frog readily captures any insects or small anima!s that approach it closely. T'adpoles are commonly satisfied to wait patiently for their food, and even the adults do not often search actively for food. Sexual maturity is reached in about three or four years, being latest for those varieties that pass the first winter in the tadpole stage. It is generally believed that frogs live for twelve, fifteen or even twenty years.

During the tadpole stage they furnish tempting morsels for fish, reptiles, some mammals, and other frogs, and especially for wading birds, like herons and cranes. Their defenseless condition and the shallowness of their natural habitats at this period make them ready prey, and it is in the prevention of this. wholesale destruction that man may profitably intervene. In the adult frog stage the relentless pursuit by birds and reptiles is continued until of the hundreds of eggs deposited few become reproducing individuals. Only slight revenge for all this slaughter can be taken. They may occasionally capture disabled fish or small fish of sluggish habits found in the mud or on the bottom, and 
instances are recorded of their eating snakes, toads, and young birds, but insects and lower forms are their staple diet.

The species of frogs commonly eaten are the bullfrog (Rana catesbiana), the green frog (Rana clamata), the spring frog (Rana virescens), and the western bullfrog (Rana pretiosa and Rana aurora).

\section{FRESH WATER “CLAMS." (Unios.)}

In nearly all of the lakes and streams of the Middle West are to be found mussels, which are known here as fresh water, soft shelled clams, and though not one person in a thousand has ever eaten them they are an edible delicacy. Frequently these "clams" are found at the edge of lake or stream, near the shore, and in some localities they are gathe:ed and used' for fish bait, especially for crappies.

To catch these "clams" the old method employed by Indians and Canadian explorers is probably the best. Take an old fish net or hammock or branch of a tree, weight it down so that it will drag on the bottom, fasten with long ropes to a row boat and row slowly. As soon as the net or brush touches the shells, which are partly open to catch food, they will close and fasten to the drag. In this way hundreds may be gathered in an hour where the "clams" are reasonably plentifu? 


\section{ENEMIES OF FISH.}

The common enemies of small fish are kingfishers, ducks, mud hens (coots), fishhawks, snakes, frogs, muskrats, owls, turtles, cormorants, herons, opossums, crawfish and water rats. All of these are destroyers of small fry, and it is for the purpose of killing off these fish destroyers that a gun of small size is recommended in the angler's outfit.

While the above named enemies of small fish are very destructive in small lakes, there are no greater destroyers of fish life than the big fish. The dogfish, the bass, the pike (pickerel), the catfish are very cannibalistic and will frequently attack other fish of nearly their own size. It is not uncommon to find a pound fish in the gullet of a five pounder, though the writer has never known an instance where the big fish had swallowed another of the same variety. Bass are often found to have devoured small suckers, tench, sunfish and perch, but so far as observed no bass have been found in their stomachs. The dogfish is very destructive to spawning beds, and in this respect is not much aifferent from the carp, which spawns on the surface of the water and then raids the spawning beds of the bass, pike and perch, and, returning devours much of its own spawn.

The fish destroyers are numerous and it seems a Providential arrangement to keep down the supply.

\section{THE LAMPREY.}

\section{(Petromyzon marinus unicolor.)}

The greatest enemy of fish in some of the western lakes, especially those of shallow depth and consequently warm water, is the lake Lamprey, or Lamprey Eel. This fish like animal is not an eel and resembles the latter only in appearance. It is more commonly known in the East as "rock sucker" because it is sometimes found clinging by its moutin to stones. A peculiarity of this fish is that it requires three to four years to reach maturity and reproduce its kind, when it dies, seldom living more than three months after maturity.

The Lamprey may be called a blood sucker. Its mouth fastens to the side of a sucker, pickerel, catfish, bass or any other fish that it may come in contact with, and it cannot be shaken off until its appetite is satisfied. It is not often that a fish thus attacked survives, the lamprey generally sucking the life out of the fish before releasing its hold. 


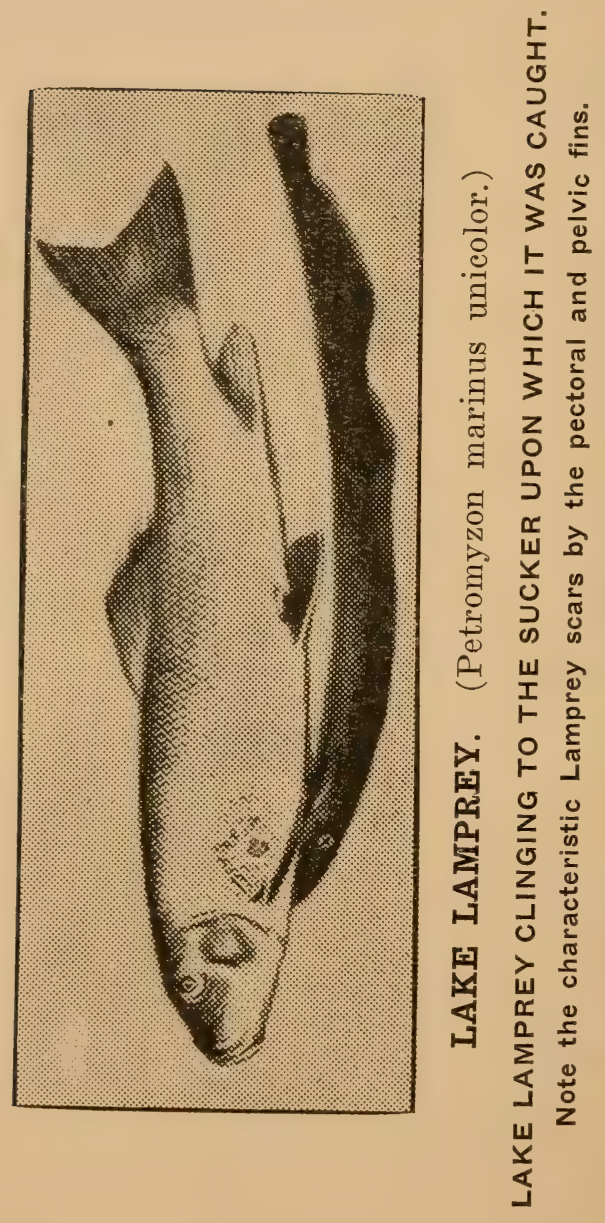




\section{HOW TO CATCH FISH.}

The means for catching fish are so numerous that it would require a volume larger than this book to describe them all. However, some of the most common methods are given as well as some of the secrets known only to life long fishermen, many of whom learned these secrets from the Indians and Southern Aborigines.

The most common bait in use for lake and river angling is the frog or minnow, though the fly and other artificial baits are rapidly supplanting them as being more successful, inexpensive and cleaner to handle. The writer, who has continued a line of experiments from the time he used a willow pole for a rod, a piece of twine for a line and a bent pin for a hook, covering a period of many years, has almost whoily discarded the live bait, finding much more satisfaction and pleasure in the use of the various artificial baits. Especially is this true of the bass fly. But one must have a variety of such bait and understand when and how to use them. After all, a knowledge of the habits of the fish, the waters in which they are found, the direction of the wind and temperature, are most essential.

Bait casting affords the most sport and is more likely to result in good catches than either trolling or still fishing.

Having secured a good reel, whether it cost a large sum or only a couple of dollars, a rod is essential. A lancewood rod will answer, though some anglers who can afford it will insist on a steel or split bamboo rod, but in any event these should be selected with a view to the class of fishing proposed.

With a good reel, good rod and well balanced bait, whether natural or artificial the angler should, with a slight experience, be able to get both sport and fish.

Fly casting is the common form of hooking brook trout, though many anglers still adhere to the earth worm bait of their boyhood days. The artificial fly will, however, prove more effective. In fact, it is about the only successful method now employed.

Fly casting for black bass is becoming a common practice with those who care more for the sport than they ao for fish; but a skilled angler will not return home empty handed. The "Professor," and "Brown Hackle," are among the most attractive lures.

The same tackle used for taking brook trout may be used for hooking crappies, but to take these fish the fly casting should be done before sunrise or after sunset. Little success 
will attend fly fishing for crappies during any other time of the day. Use the Seth Green or Moth Miller, or some similarly bright fly, and for two hours, if located right, the angler will be treated to a series of surprises.

The writer has found the Moth Miller the most successful lure. Crappies are not gamey. They do not strike like a brook trout, nor put up such a game fight, but they are a fairly gcod substitute, and the angler who has always fished for them with angle worms or clams, will be surprised and pleased at the experiment.

\section{SECRETS OF CATCHING FISH.}

T'rout lures consist generally of the common earth worm in the early spring or the white wood worm found under the bark of trees. During the summer when the flies are abroad the artificial fly may be used with great success. But if the angler wants to stir up the big fellows he should bait with a chub minnow, a goläen shiner or similar small fish about two to three inches in length. It is the big fish that are looking for big bait. The big ones are lazy and when they see a nice fat shining minnow apparently leisurely swimming by, it looks like easy food; there is a dash, a splash, a strain on the line and the big fellow is hooked. It is up to the angler to land him.

While the author of this book discourages the use of artificial means of catching fish it is deemed a part of his mission to show how fish may be caught without either hook, line or spear. These methods are contrary to law.

By the use of Fish Berries (Cocola Indicus), one may capture a tub full of fish in a short time. First ascertain where the fish are located. T'hen scatter pills of fish berries which have been prepared by mixing the powäer with flour and water and then drying in the air. When these pills are scattered over a school of fish they are eagerly swallowed. In about five minutes the fish will come to the surface belly up. Now is the time to gather them in with the landing net and place them in a tub of water previously provided in the boat. They will lie apparently dead for ten to twenty minutes when they will revive and be as lively as ever. These fish should be put in a live box and kept for a few hours before being cooked. Perhaps a few may die but if so it is generally from rough handling and not because of the fish berries, which though a poison simply put the fish to sleep.

Another plan is that of jugging. In Germany and several 
other kingdoms of the old country poachers often follow this practice.

They take a pint or quart bottle, place in it a cup full of unslacked lime, drop in a half cup of water, fasten down the cork quickly with wire and gently drop the bottle down among the fish. In from ten to thirty minutes the lime has become slackea, the gas forms and an explosion follows which stuns the fish and they rise to the surface, where they are gathered in with landing nets. This method is preferable to the fish berries, as there is no possible ill effects from the lime.

Another similar method is the use of a half gallon jug filled with a pint of lime and a cup of water. This is used when the water is very deep and big fish are sought. The jug should be weighted with a heavy stone or it will not sink to the bottom. It will take about forty to sixty minutes for the jug to explode, but it will stun the fish within a radius of fifty feet.

A few drops of oil of rhodium or oil of cummin dropped on the bait will attract fish and they will never refuse to bite. This is a very old secret but experiments show that the slow moving fish are the ones that most readily take this doctored bait, not the bass or the trout, which come at the bait with a rush. But there are times when bass are not biting when the above oils will start them going.

\section{HOW TO CATCH MINNOWS.}

There are several ways, but it depends on how you are situated. If the minnows are to be taken from a lake the net should be about forty feet long and wide enough to reach the bottom while the top is on the surface. With one person at each end after ciropping the net, gradually draw in to shore, scooping up the fish in the belly of the net.

The most successful method of catching minnows is at the mouth of a creek, with an umbrella shaped net. Often these streams are but a few feet wide and if properly netted and the minnows are driven up by another person wading the stream from the mouth of the creek hundreds may be obtained in a single haul.

\section{CARE OF FISH.}

No fish should be kept to aie in the boat, but should be killed outright, unless they are placed in a tank for future 
use. A basliet affords the best receptacle for fish when taken and should be provided wherever possible.

When a sufficient number of fish have been taken, and this should be no more than is necessary to supply the family table, and perhaps a few for a neighbor, they should like game birds, be arrawn and packed in grass in the fish basket. Ten minutes will suffice to draw the fish of a day's catch. Then if the angler has time, the fish should be scaled. A lightning Iish scaler costs but 25 cents, and will repay its cost in once using it.

\section{CARE OF TACKLE.}

A good angler will take good care of his tackle. The reel should be oiled before starting out and should be kept free from dirt, and should be provided with a leather case. Some reels cost as much as a good watch, but few think of giving them as much care.

Nothing but a good line should be used. A good line will outlast a dozen cheap ones. When through fishing for the day the line should be hung up to dry before being rewound.

The proper way to assemble a rod is to start with the tip, connecting the joint to the handle, then attach the reel ana thread the line on the rod. When the rod is taken apart the ferrules should be plugged with cotton or paper before putting away.

Each class of hooks should be kept in a separate box, packed in the tackle box where it can be found without dis. turbing the other tackle. 


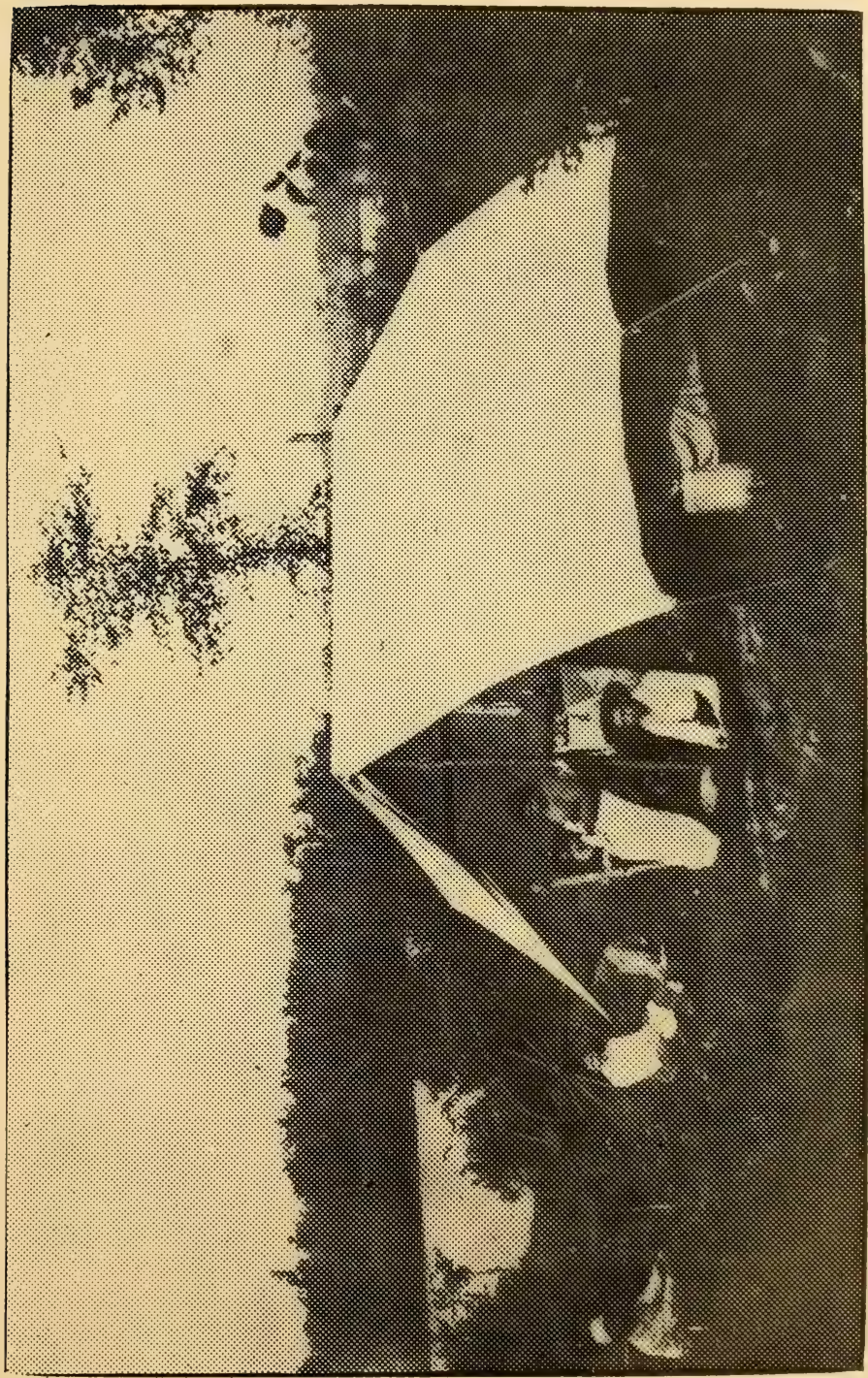




\section{CAIMP AND FISHING HINTS.}

A good shelter tent, which can be carried in a compact space, may be constructed from a canvas sheet $6 \times 12$ feet in size, with large brass eyelets at the ends. With this canvas one may make a tent cover as protection from the sun, rain or wind, using a cross pole propped at each end in the branches of two small trees. This makes a good roof, strings passed through the eyelets being fastened to the ground or shrubs. To make a wind shelter, this canvas may be passed around three small trees, forming a semi-circular enclosure. It is unnecessary to add that outing parties will find such an addition to their equipment a great convenience.

There are many other conveniences for an outing trip to be found in all the large supply houses, and the angler must choose for himself or herself, according to their means and requirements. It would be impossible to enumerate them all, many of which are good and serviceable, and many of which are worthless.

In washing flannels and woolens don't wring them dry; hang them out without wringing and they will not shrink.

Telescope or field glass is a great convenience.

To test the freshness of meat insert the blade of a knife into the flesh; your nose can tell.

Fish decay quickly. Trout should be drawn as soon after catching as convenient. Large fish should have the gills removed as soon as possible in hot weather.

'To make jerked meat from fresh killed venison or beef, cut the meat from the bones, then cut the meat into strips lengthwise with the grain, about three inches square; salt th:e strips and keep them under cover for five or six hours; hang the strips up to the limb of a tree for a few hours; dry them partially in a smoke barrel or box for 6 hours, salt again and hang up for two or three days. Such meat will keep for twenty years if kept dry.

To get cold water take a corked jug; to the cork attach a strong cord; to the handle of the jug attach a small rope; row out into the lake where it is very deep; tie a heavy stone to the jug to make it sink; drop the jug overboard, being careful that the line attached to the cork goes out freely. When the jug has reached the hottom, pull out the cork. The jug will fill with cold water. When full draw in with the line attached to the handle. The water will be very cold, especially if the lake is fed by underground springs.

A good compass should be taken along where much tramp- 
ing through the woods is anticipated, for it is very easy to get lost. A man naturally turns to the right in the woods, while a woman leans to the left. This has been demonstrated hundreds of times.

A device for looking into the depths of the water may be constructed of haif inch pine, five inches square at each end and four to five feet long. The lower end is covered with

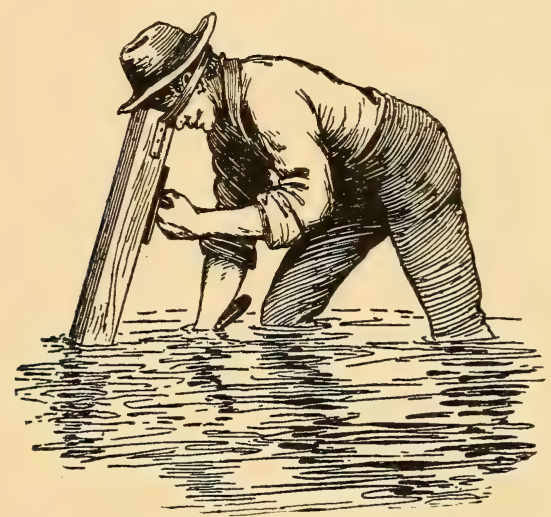

glass and the upper end is cut to fit the face. With such a telescope one may see "things" at a depth of twenty to twenty-five feet on clear days. Such "telescopes" are often used when snaring through the ice in winter or in searching for "clams" or crawfish in shallow water.

Whistle-Very often the whistle may show your presence, or may be used as a signal. The rule of the woods is: One long shrill blast-Game here, come, Two long blasts: Where are you? Three long blasts: Wait, I am coming. Three blasts at intervals: I am lost. The same signals are useà with rifle or shot gun.

Sunglass, or flint lighter-Very often hunters lose their matches or they become wet. The sunglass or "reading glass" or the flint lighter then come in handy. The glass can only be used when the sun shines, but the flint lighter, if kept in a rubber or oil skin cover, may be used at all times even if the hunter is unfortunate enough to be "dumped" in the water. 
Electric Light-The pocket electric flash light will be found to be an important adjunct to the huntsman's kit. It can be used in all kinds of weather and is always ready.

Pistol, Small Rifle or Shotgun-Any of these are valuable acquisitions to the angler's outfit, for the reason that one of ten encounters wolves, wild cats, raccoons, squirrels or tramps. Except the latter (which are the most dangerous) one may secure fine specimens by having fire arms. Never keep a loaded gun in wagon, boat or tent.

Axe and Knife-A gooä hunting knife or axe is essential. With such keen edged tools one may easily construct a temporary camp and feel assured of safety in the wildest locality.

Tenting Outfits-Tents may be selected to suit the hunter or angler, but no one should forget the necessity of a couple of pounds of wire nails as a quick means of fixing the frame.

Camp Grounds-Select a high place, sloping to river or lake, dig a trench on the upper and side lines near the base of the tent, so that in case of rain the interior of the tent will not be flooded.

Lost in the Woods-If you find you are lost, sit down. If you have lost your bearings try to realize your position by the compass. If you have "blazed your way" with the axe it will be very easy to retrace your steps. This is what you should have done.

Blazing the Trail-When you leave the main road and go into the woods, with your axe clip off the bark of the trees, about shoulder high, at least every fifty feet. If this course is pursued one can never be lost.

Take only old clothes for outing or fishing. An extra pair of shoes will come in handy, as well as two changes of underclothing. In wading the trout streams in warm weather the writer generally wears a pair of canvas shoes, a pair of overalls, flannel shirt and dark coat. Never wear bright colors while fishing trout. Brook trout can see farther than any other fish. Never wear white waist or hat; olive green or dull grey are gooá colors.

To build a camp fire drive two three inch stakes in the ground at an angle of 90 degrees. Find four green logs, short ones, lay one above the other against these stakes. Dig an 
oblong hole at the foot of the ground log, about six inches deep, about 18 by 24 inches in size, then build fire, using small dry twigs underneath. After the fire is well started lay over all two dry logs. After this fire is sufficiently burned, cooking may be commenced, and all of the dishes prescribed in this book may be cookea.

Take care of your matches-A screw top bottle is one of the best means. Have such a bottle always filled and held in reserve for emergency. You might fall in the water destroy your matches and put your flint lighter out of business. The matches in the bottle will always be safe.

In tenting, a convenient bed is made by having a canvas sheet 3 feet wide by 7 feet long. Get two six or eight inch logs, 3 feet long and fasten to each end of the canvas, the canvas having brass eyelets. Then get two small saplings of sufficient length and fasten them to the two logs on each side of the canvas. This will make a very convenient bed.

Every camper and outer shoulä provide himself or herself with a dozen yaräs of mosquito net.

When in permanent camp a good plan to keep water cool is to have a keg, dig a hole in the ground about the water level, place the keg therein and having a lid on the top of the keg, cover it with four or five layers of wet cloth. This will keep the water thirty to forty degrees colder than if kept open in camp.

A great deal depends on the location of a camp. And it is worth a few hours' consideration in its selection. It should be in close proximity to good water, fuel and protection from storms.

In buying waterproof boots the canvas covered gum boot is the best as it will stand harder usage than the all-rubber boots and is much lighter.

Never take any whiskey or other stimulant in the boat. It is a dangerous proposition. If one must have it leave it in camp to be taken after your return. 


\section{CAMP SUPPLIES.}

One of the most difficult problems confronting the camper is that of taking as small an outfit as possible and still have necessities for camp life. There are knock down stoves and full sets of camp furniture to be had at every supply house. The aim has been to condense the equipment into the smallest possible space and reduce it to the smallest weight.

The writer is not much in favor of camp stoves unless the camp be made during the winter months when a stove is essential in the tent or cabin. Rather the stove is to be discouraged during the summer months. The camp fire and a knowledge of camp cooking without the stove will furnish more real enjoyment during an outing trip than if the conveniences of the kitchen are transplanted to the woods.

With the necessary pots and pans any one who will observe the directions given in this book may serve up roasts, fries, broils, stews or baked dishes that will be far more palatable than home or hotel cooking.

To equip an outdoor camp for a party of four they should have aside from their tent equipment, the following,

1 Axe.

1 Camp coffee pot.

1 Camp fry pan.

3 Stew kettles, two of equal size and one smaller.

2 Bake pans.

4 Camp plates.

4 Camp cups.

4 Knives.

4 Spoons.

4 Forks.

1 Salt cellar.

1 pepper dreage.

1 Large spoon.

1 Large fork.

I Ladle dipper.

I Turnover.

I Whetstone.

1 Can opener.

1 Butcher linife.

The camp ration must be chosen with great care and with regard to the locality in which the camp is to be pitched. No allowance is made for game or fish which may be procured. For each week of camp life for four persons the following 
quantities and articles are suggested, after thirty years of experience:

20 Pounds of flour.

6 Pounds of Corn meal.

5 Pounds of Navy beans.

6 Pounds of Salt pork.

10 Pounds Select bacon.

15 Pounds Potatoes.

7 Pounds Onions.

3 Pounds of dried fruit.

I Large ham.

1 Gallon of sour pickles.

I Quart of Syrup.

1 Box of mustard.

1 Sack of salt.

3 Pounds of coffee.

2 Pounds of Tea.

6 Pounds Sugar.

3 Pounds Cheese.

1 Can baking powder.

1 Can baking soda.

1 Pkg. matches.

Soap.

Candles.

If for a longer trip take same amount for each week.

\section{HOW TO COOK FISH.}

We have all heard about how to cook wild fowl and fish by encasing them in clay, but the clay is not always obtainable; what then? Take a bass, perch or pike, dress it. After rinsing it well place a piece of bacon or salt pork inside, then wrap the fish in two or three layers of brown paper. Soak the whole package until wet through. Now remove the coals from the fire, dig a trench through the hot ashes, imbed the fish encased in the brown paper, draw the hot ashes anä coals around it, and if necessary to maintain heat, build a small fire over the fish. In thirty to forty minutes the fish will be ready to serve.

\section{PLANKED FISH.}

It all depends upon the kind of fire you have, when cooking planked fish. First clean the fish. Place inside it a 
piece of bacon or salt pork, and a little celery or onion. Nail the fish to a wide board in such a way that it may be turnea towards the fire. It is essential to have a fire: of hot coals, and the cooking of such a fish will require forty-five to sixty minutes time.

\section{TO SIMOKE FISH.}

The great northern pickerel, muscallonge, wall eyed pike, black bass, striped perch and white fish as well as many other varieties of fish, may be preserved by smoking, if simple directions are followed.

Procure a barrel or box or small canvas enclosure. Construct three layers of cross bars, of wire, willow saplings or netting. Place on these frames the fish desired to be smoked, first having aressed them and split them down the back (it is best to remove the backbone), lay them flat on the frames. Build $a_{4}$ smudge under them and smoke for two to four hours under a steady hot smoke. After this, if possible, dry the fish in a hot oven for fifteen or twenty minutes. If an oven is not available, nail the fish to a board and place them near a camp fire for half an hour. Salt them thoroughly and they will keep for several months, and will equal the best finnan haddie or other smoked fish. 


\section{CAIMP COOKING.}

To roast potatoes put them in hot ashes and cover; keep fire enough on top to insure steady heat. They will cook in forty-five minutes if ashes are properly prepared.

To roast corn on the ear follow the same plan as for potatoes, leaving the husks on; forty minutes time will be required; remove from ashes, pull off husks and serve.

To roast eggs follow the same plan; five to six minutes will cook them nicely.

Liver and bacon-Drop slices of liver in hot /water for two minutes; remove and drop into frying pan where bacon has been previously cooked.

To cook rabbit-Skin and dress; remove head; cut in small pieces at the joints and fry in butter or with bacon. If for stew cook same as stewed chicken.

To cook Partridge, Quail or Prairie Chicken; dress, skin and fry; or dress and encase in clay and roast in hot coals and ashes, either with feathers on or removed.

Baked Beans-The night previous soak beans, one cup for two persons, using plenty of water and a large dish. In morning drain and place in kettle and boil until skins will separate when blown upon. Place in closed jar, with piece of fat bacon or salt pork; add tablespoon sugar; cover jar with tight cover, place jar in hot ashes and cover with hot coals or fire; cook for two hours. Leave an inch or two of space on top of beans for expansion and gas. If placed in campfire and left over night will be ready for breakfast.

Tea is the best for a camp or long trip through noods. A small quantity will go a long ways; it is easily prepared. Use a pinch of tea for each person; steep a few minutes until right color is obtained. Tea is used by all old time hunters and cruisers.

Pancakes-Mix night before. Flour and water (milk if available), in morning add pinch of salt, little sugar and flour enough to make a soft batter. Add teaspoon soda to each quart batter; fry in bacon drippings.

Soups and stews are frowned down by campers, because of the necessary dishes. 


\section{EMERGENCY MEDICINES.}

Keep the mouth shut, the head cool, the bowels open and the feet dry, and there will be little use for your medicine case. Still there will be times when the emergency case will be found necessary. Constipation and diarrhoea, cramps, chills and wounds are the most common affections to contend with on an outing trip.

For constipation use cathartics, any kind; for diarrhea use sun cholera cure or apply warm bandages to stomach. Browned flour, vinegar and salt is good for a drink. Hot ginger tea is good.

For cuts or wounds, bandage thoroughly. If an artery has been cut tie bandage above the wound and use a stick to tighten the bandage, then go for a surgeon, if it is a dangerous case.

Baking soda is a great relief for ivy poisoning.

For toothache use Wizard Oil, or warm solution of vinegar and salt. Peroxide of Hydrogen is also very good in allaying tooth troubles.

For earache, put a small portion of finecut tobacco in a tablespoon with water; steep over fire, drop few drops in ear; pain will cease at once.

For fever and ague take frequently 2 grain capsules of quinine.

It is a good plan to have a dozen mustard plasters. They can be had at any drug store.

The hypodermic syringe is also worth consiäeration in cases of fatigue, drowning, over exertion. Learn how to use it.

For poisoning warm water and mustard is good.

If struck by lightning place patient on ground, throw water in face and remove clothes; let patient lie close to ground. 


\section{PROPER FISHING BOAT.}

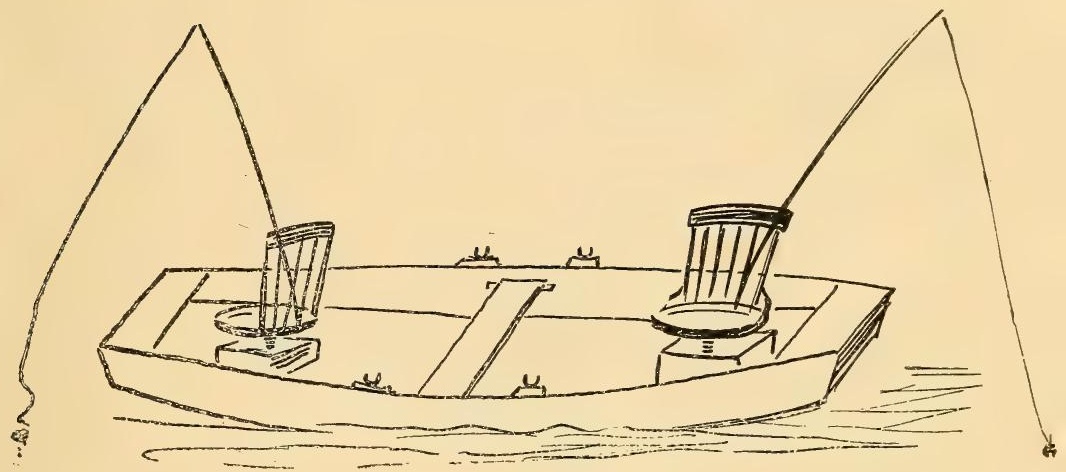

Proper boat for fishing. It is a flat bottom boat twelve to eighteen inches in depth, eighteen feet long and four feet six inches in wiuth, with fixed seats at each end. There will be less liability of danger and more comfort from using such a boat than any other. Fishermen do not require speed and a single pair of oars in such a boat will propel two or four persons at sufficient speed. 


\section{CHOICE OF FLIES.}

Fly fishing is in its infancy in America generally, and especially in this part of that happy land. In the European countries files are classified for use according to the country and according to season. Thus there are sand flies suitable for Norway, for Ireland, the Dee, the Tweed, the Usk. So there are trout flies for the Severn, Wye, Lugg, Teme, Mormow, etc.; for the Yorkshire, Cumberland and Westmoreland rivers and streams and for the various lakes. Fishermen in this part of the world do not distinguish between streams. Substantially the same flies are used through the Rocky mountains, Wisconsin and Minnesota and in New England. In Canada the subject has advanced a step further in evolution. On the Nepigon, for example, it is an established tradition that you use number one salmon flies, especially Jock Scott, Silver Doctor, "Rams Bottom's President," Durham Ranger, Dusty Miller, etc. For the Maine salmon fishing large flies are used; in Northeast Canada the flies run very small.

In countries where the art has reached a further state of development, flies are arranged according to the months. A standard English book describes as the best flies for April, Iron Blue Dun, Olive Quills, Gold Ribbed Hare's Ear, Goose Dun, March Brown and Hammond Adopted, Rough Olive, White Church and the Grannum. The best flies for May, Red Palmers, Olive Duns, Cow Dun Alder, a Black Gnat, Yellow Dun, Ginger Quil, Pink Wickham. One celebrated entomological arrangement, according to season, iș "Rolands." The flies therein described for April and May, like those just enumerateä, are rather neutral cinnamon colors for April and more yellow and blue colors for May. 


\section{IMINNOWS FOR BAIT.}

The use of minnow bait for catching wall-eyed pike, pickerel, perch, and sometimes bass, is frequently employed in this section. Anglers differ as to the proper method of hooking this bait. If it is true that big fish swallow the minnow head first, it would seem that the first cut here shown would be the proper method for attaching the hook.

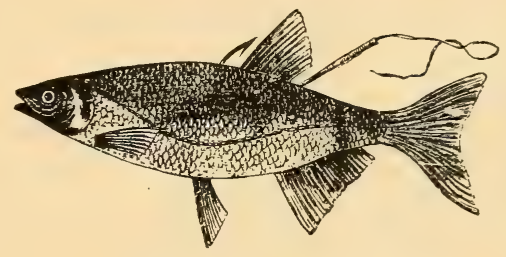

But if the big fish swallow the minnows tail first, then the method shown in the following cut would seem to be appropriate.

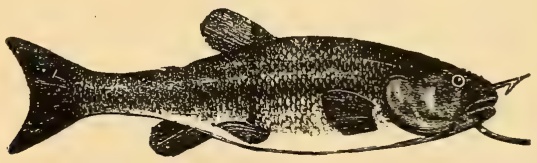

The big fish take the frog through a rear attack. They also take the minnow in the same manner, but whether they do so at all times is a question. They evidently do take smali fish head first when not attached to a hook, but when used as bait it has been proven that they will swallow the minnow in most any way. 


\section{OPEN SEASON FOR FISHING.}

The laws of the western states have recently been changed, the principal changes being in the dates for taking certain fish. The following extracts from the game laws cover every point likely to arise, or about which there may be any dispute. There will be no other changes before spring of 1909 , if then.

\section{Minnesota.}

Brook trout-any variety-April 15th to Sept. 1st.

Black Bass, Gray Bass or Oswego Bass, May 29th to March 1st, following.

Pike, Perch, Muscallonge, Sunfish, Lake Trout, Catfish or any other variety of fish-May 1st to March 1st, following.

Pickerel, Suckers, Bullheads, Redhorse and Carp may be taken at any time with either hook and line or spear. There is no limit to the number of these fish that may be taken. Artificial light may be used except during May and June.

It is unlawful to have in possession for sale or to sell any brook trout or black bass at any time. All other fish may be sold provided they are caught in the manner prescribed by law, with hook and line, except in certain cases, where seines are permitted and are licensed by the game and fish commission.

The number of fish that may be taken in one day is limited to twenty-five, except pickerel, suckers, redhorse, carp and bullheads. Crappies and sunfish are restricted to 25 .

Nonresiaents temporarily in Minnesota may ship outside the state any fish caught here provided the shipper accompanies the fish and the package or box is properly and plainiy marked, giving name of shipper, the consignee and the contents of the package. Fifty pounds is the limit that may thus be taken.

One hook and one line is all the law permits, but the com. mission has ruled that the "gang" hook, tandem hook or artificial bait constitutes one hook.

\section{Wisconsin.}

Brook Trout-any variety-May 1st to August 15th. Ten pounds is the limit for a day's eatch.

Black Bass, Yellow Bass or Oswego Bass, Green Bass, Rock Bass, Silver Bass, White Bass, Pike, Catfish, Muscallonge and Sturgeon-May 25th to March 1st, following. Under the law these are designated as the game fish of Wisconsin. 


Rough Fish-In Wisconsin Buffalo fish, Carp, Dogfish, Garfish, Eelpout, Red Horse, Sheepshead and Suckers are legally known as Rough Fish. A license is required to take the rough fish with nets or seines as in Minnesota, though the fee is five dollars, whereas in Minnesota it does not exceed one dollar.

The sale of Brook Trout is prohibited and they cannot be shipped either within or without the state, unless accompanied by the shipper.

\section{North Dakota.}

Pike, pickerel, perch, crappies, trout, buffalo, bass and muscallonge between May 1st and January 1st, except in streams and lakes where fish has been planted, there from May 1st to October 1st. Hook and line only can be used.

\section{South Dakota.}

\section{(Same as North Dakota.)}

\section{Upper Michigan.}

Speckled trout, grayling, Caiifornia trout and landlocked salmon, from May 1st to September 1st, with hook and line only. Less than six inches long protected. Black bass may be taken with hook and line only, from May 20th to April 1st following thereafter, must not be sold during closed season. 


\section{OPEN SEASON FOR GAIME.}

\section{Minnesota.}

Turtle dove, snipe, prairie chicken or pinnated, whitebreasted or sharp-tailed grouse, woodcock, upland plover and golden plover, September 1st to Nov. 1st.

Quail, partridge, ruffed grouse or pheasant, other than Mongolian, Chinese, ring neck or English pheasant, October 15 th to December 15th.

Wild duck, wild goose, brant, or any variety of aquatic fowl, September 1st to December 1st:

Unlawful to shoot or kill more that twenty-five game bircis per day.

Deer, November 10th to November 30th.

Male moose, November 10 th to November 30th.

To hunt big game, such as deer and moose, license requireā; non-resident's fee, $\$ 25.00$; for small game $\$ 10.00$, issued by county auditor; resident's fee, $\$ 1.00$

Elk protected at all times.

\section{Wisconsin.}

Woodcock, partridge, pheasant or grouse of any variety, plover or snipe, September 1st to December 1st.

Prairie chicken, September 1st to October 15th, in following counties: Adams, Barron, Burnett, Bayfield, Buffalo, Clark, Crawîrd, Douglas, Dunn, Eau Claire, Jackson, Juneeu, Marquette, Monroe, Pepin, Polk, Portage, Richland, Sawyer, Vernon, Washburn, Wanshara, Wood.

May take in one day or have in possession:

Fifteen prairie chickens, grouse or woodcock.

T'wenty-five partridge or pheasant.

Thirty wild geese, wild ảucks, plover or snipe.

Non-residents with license may take fifty game birds from state when he accompanies them, not piore than above number of any variety.

Wild duck, brant or other aquatic fowl, excepting wild geese, September 1st to January 1st.

Wild geese, September 1st to May 1st.

Deer, November 10 th to November 30 th, except in Adams, Richland and Marquette counties, where open season is November 20 th to December 1st.

Closed all year in Calumet, Columbia, Fond du Lac, Man- 
itowoc, Sauk, Sheboygan, La Crosse, Monroe, Trempeleau and Vernon.

Unlawful to hunt without a license. Fee to non-residents is $\$ 25.00$ for hunting all game (not protected), including deer; $\$ 10.00$ for hunting game other than deer. Fee to residents, $\$ 1.00$. For rabbit or squirrel, September 1st to March 1st.

\section{Michigan (Upper Peninsula).}

Ducks, geese and all wild water fowl, September 1st to January 1st. Jack snipe, bluebill, canvas-back, pin-tail whistler, spoon-bill, butter-ball and saw bill ducks, March 2nd to April 10th. No device permissible.

Prairie chicken, wild turkey and wild pigeon, protected until 1910.

Partridge, quail, spruce hen and woodcock, October 15th to November 30 th.

Deer, November 10 th to 30 th, inclusive. No person is per. mitted to kill more than two in one year.

Moose, elk and caribou are protected until 1913.

For black and gray squirrels, October 15 th to November 30 th.

License required to hunt deer. Fee to non-residents, $\$ 25.00$; residents $\$ 1.50$.

\section{North Dakota.}

Prairie chicken, pinnated, sharp-tailed and ruffled grouse or woodcock September 1st to October 15th.

Wild duck, wild goose, crane or brant, Sept. 1st to May 1st.

Deer, from November 10th to December 1st; hounảs or dogs, also spring guns, prohibited in hunting same.

Permit required for hunting within state, issued by county auditor and endorsed by game warden. Fee for non-residents, $\$ 25.00$; for residents, 75 cents.

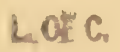




\title{
LIST OF SPECIES OF FISHES KNOWN IN THE GREAT LAKES OR THEIR CONNECT- ING WATERS.
}

\author{
From Report of U. S. Fish Commission.
}

In the following list are given the fishes known to live in the Great Lakes or their connecting waters. This includes not only the streams and smaller lakes directly tributary to the Great Lakes but also the upper St. Lawrence River and the waters tributary to it. The species not known to occur elsewhere than in the hydrographic basin of the Great Lakes are indicated by a star.

1. Petromyzon marinus unicolor (De Kay). Lamprey eei.

2. *Ichthyomyzon concolor (Kirtland). Silver lamprey.

3. Lampetra wilderi (Gage). Brook lamprey.

4. Polyodon spathula (Walbaum). Paddle-fish. Only one specimen recorded from Great Lake Basin; that from Lake Erie.

5. Acipenser rubicundus Le S. Lake sturgeon.

6. Lepisosteus osseus (L.). Long-nosed gar.

7. Levisosteus platostomus Rafinesque. Short-nosed gar.

8. Amia calva Linnaeus. Dog-fish or bowfin.

9. Ictalurus punctatus (Rafinesque). Channel cat-fish.

10. Ameiurus lacustris (Walbaum). Great Lakes cat-fish.

11. Ameiurus natalis (Le Sueur). Yellow cat-fish.

12. Ameiurus vulgaris (Thompson). Bullhead.

13. Ameiurus nebulosus (Le Sueur). Common bullhead.

14. Ameiurus melas (Rafinesque). Small black bullhead.

15. Noturus flavus Rafinesque. Stone cat.

16. Schilbeodes gyrinus (Mitchill).

17. Schilbeodes exilis (Nelson).

18. Schilbeodes miurus (Jordan).

19. * Carpiodes thompsoni Agassiz. Lake carp sucker. *

20. Calostomus catostomus (Forster). Long-nosed sucker.

21. Catostomus commersonii (Lacepede). Common sucker.

22. Catostomus nigricans Le S. Black sucker.

23. Erimyzon sucetta oblongus (Mitchill). Chub sucker.

24. Minytrema melanops (Raf.). Striped sucker.

25. Moxostoma anisurum (Rafinesque). White-nosed sucker.

26. Moxostoma aureolum (Le Sueur). Common redhorse.

27. Moxostoma breviceps (Cope). Short-headed redhorse.

28. Campostoma anomalum (Raf.). Stone-roller.

29. Chrosomus erythrogaster Rafinesque. Red-bellied dace. 
30. Pimephales promelas Raf. Fat-head minnow.

31. Pimephales notatus (Rafinesque). Blunt-nosed minnow.

32. Semotilus corporalis (Mitchill). Fall-fish.

33. Semotilus atromaculatus (Mitchill). Creek chub.

34. Leuciscus elongatus (Kirtland). Red-sided minnow.

35. Leuciscus neogaeus (Cope).

36. Leuciscus margarita (Cope).

37. Opsopoeodus emiliae Hay.

38. Opsopoeodus megalops (Forbes).

39. Abramis crysoleucas (Mitchill). Roach.

40. Hybognathus nuchale Agassiz.

41. Cliola vigilax (Baird \& Girard).

42. Notropis anogenus Forbes.

43. Notropis cayuga Meek. Cayuga minnow.

44. Notropis heterodon (Cope).

45. *Notropis fretensis (Cope).

46. Notropis blennius (Girard). Straw-colored minnow.

47. *Notropis volucellus (Cope)

48. Notropis hudsonius (De Witt Clinton). Shiner.

49. *Notropis hudsonius selene (Jordan). Lake Superior shiner.

50. Notropis whipplii (Girard). Satin-fin minnow.

51. Notropis cornutus (Mitchill). Red-fin.

52. *Notropis cornutus frontalis (Agassiz).

53. *Notropis cornutus cyaneus (Cope).

54. Notropis atherinoides Rafinesque.

อ5. Notropis arge (Cope).

56. Notropis rubrifrons (Cope).

57. Notropis umbratilis (Girard).

58. Notropis umbratilis cyanocephalus (Copeland.)

59. Ericymba buccata (Cope).

60. Rhinichthys cataractae (Cuvier \& Valenciennes). Longnosed aace.

61. Rhinichthys atronasus (Mitchill). Black-nosed dace.

62. Rhinichtings atronasus lunatus (Cope).

63. Hybopsis dissimilis (Kirtland).

64. Hybopsis storerianus (Kirtland).

65. Hybopsis kentuckiensis (Raf.). River chub.

66. Couesius plumbeus (Agassiz).

67. Couesius dissimilis (Girard).

68. Exoglossum maxillingua (Le Sueur).' Cutlip minnow.

69. Anguilla chrysypa Rafinesque. Common eel.

70. Hiodon alosoides (Rafinesque). Mooneye.

71. Hiodon tregisus Le Sueur. Toothed herring. 
72. Dorosoma cepedianum (Le Sueur). Hickory shad. Probably introduced through canals from Mississippi basin, and possibly go through the Erie Canal.

73. Pomolobus chrysochloris Rafinesque. Probably not native, but introduced from the Mississippi basin by means: of canals.

74. Pomolobus pseudoharengus (Wilson).

75. Coregonus quadrilateralis Richardson. Rounä white-fish.

76. Coregonus clupeiformis (Mitchill). Common white-fish.

77. Coregonus labradoricus Richardson. Labrador whitefish.

78. *Argyrosomus osmeriformis (H. M. Smith). Smelt of New York lakes.

79. Argyrosomus artedi (Le Sueur). Lake herring.

80. Argyrosomus artedi sisco Jordan. Cisco of Lake Tippecanoe. Only in certain small lakes in Wisconsin connected with Lake Michigan and certain small lakes in northern Indiana in the Wabash basin..

81. *Argyrosomus hoyi Gill. Hoy's white-fish.

82. *Argyrosomus prognathus (H. M. Smith). Long-jaw . white-fish.

83. *Argyrosomus nigripinnis Gill. Blackfin white-fish.

84. *Argyrosomus tullibee (Richardson). Tullibee whitefish.

85. *Argyrosomus tullibee bisselli Bollman.

86. Cristivomer namaycush (Walbaum). Lake trout.

87. *Cristivomer namaycush siscowet (Agassiz). Siscowet.

88. Salmo salar Linnaeus. Atlantic salmon.

89. Salmo salar ouananiche McCarthy. Ouananiche.

90. Salvelinus fontinalis (Mitchill). Brook trout.

91. *Thymallus tricolor Cope. Michigan grayling.

92. Umbra limi (Kirtland). Mud minnow.

93. Lucius vermiculatus (Le Sueur). Grass pike.

94. Lucius reticulatus (Le Sueur). Pickerel.

95. Lucius lucius (Linnaeus). Great pike.

96. Lucius masquinongy (Mitchill). Muskallunge.

97. Fundulus diaphanus (Le Sueur). Grayback minnow.

98. Fundulus diaphanus menona (Jordan \& Copeland).

99. Fundulus dispar (Agassiz).

100. Fundulus notatus (Raf.). Top minnow.

101. Eucalia inconstans (Kirtland). Brook stickleback.

102. *Eucalia inconstans cayuga Jordan.

103. *Eucalia inconstans pygmaea (Agassiz).

104. Pygosteus pungitius (Linnaeus). Nine-spine stickleback. 
105. Gasterosteus bispinosus (Walbaum). Common stickleback.

106. Percopsis guttatus Agassiz. Trout perch.

107. Aphredoderus sayanus (Gilliams). Pirate perch.

108. Labidesthes sicculus (Cope). Skipjack.

109. Pomoxis annularis Rafinesque. Crappie.

110. Pomoxis sparoides (Lacepede). Calico bass.

111. Ambloplites rupestris (Raf.). Rock bass.

112. Chaenobryttus gulosus (Cuv. \& Val.). Warmouth.

113. Apomotis cyanellus (Rafinesque). Blue-spotted sun-fish.

114. Lepomis megalotis (Rafinesque). Long-eared sun-fish.

115. Lepomis pallidus (Mitchill). Bluegill.

116. Eupomotis euryorus (McKay). Red-eared sun-fish.

117. Eupomotis gibbosus (L.) Pumpkin-seed.

118. Micropterus salmoides (Lacepede). Large-mouthed black bass.

119. Micropterus dolomieu Lacepede. Small-mouthed black bass.

120. Stizostedion vitreum (Mitchill). Wall-eyed pike.

121. Stizostedion canadense (Smith). Sauger.

122. Stizostedion canadense griseum (De Kay).

123. Perca flavescens (Mitchill). Yellow perch.

124. Percina caprodes (Rafinesque). Log perch.

125. Percina caprodes zebra (Agassiz).

126. Hadropterus aspro (Cope \& Jordan). Black-sided darter.

127. Cottogaster copelandi (Joräan). Copeland's darter.

128. *Cottogaster cheneyi Evermann \& Kendall. Cheney's darter.

129 Cottogaster shumardi (Girard). Darter.

130. Diplesion blennioides (Rafinesque). Green-sided darter.

131. Boleosoma nigrum (Rafinesque). Johhny darter.

132. Boleosoma nigrum olmstedi (Storer). Darter.

133. Ammocrypta pellucida (Baird). Sand darter.

134. *Etheostoma boreale (Jordan). Northern darter.

135. Etheostoma coeruleum Storer. Rainbow darter.

136. Etheostoma flabellare Raf. Fan-tailed darter.

137. Etheostoma flabellare lineolatum (Agassiz).

138. Boleichthys fusiformis (Girard).

139. Microperca punctulata Putnam. Least darter.

140. Roccus chrysops (Raf.). White lake bass.

141. Aplodinotus grunniens Rafinesque. Fresh-water drum.

142. Cottus ictalops (Rafinesque). Blob.

143. *Cottus ricei Nelson. Rice's blob.

144. Cottus pollicaris (Jordan \& Gilbert). 
145. *Cottus spilotus (Cope).

146. *Uranidea franklini (Agassiz).

147. *Uranidea kumlienii Hoy.

148. Uranidea gracilis (Heckel).

149. *Uranidea formosa (Girard).

150. *Uranidea hoyi Putnam.

151. *Triglopsis thompsoni Girard. Fresh-water sculpin.

152. Lota maculosa (Le Sueur). Ling. 


\section{GENERAL INDEX.}

Page.

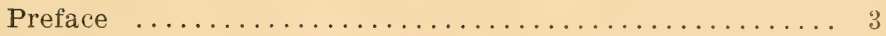

Fishes Known by Many Names................ 4

Whipping Trout Streams ................. 5

Trout-How to Angle for................... 6

Flies and Tackle .................. 6

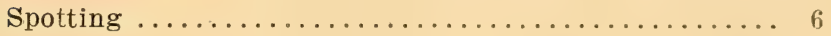

Reels and Rods ..................... 6

Fly Casting ....................... 7

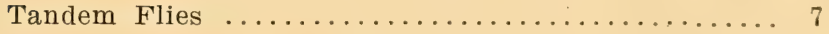

Landing Net and Creel ................ 7

Trout-Brook-Description of $\ldots \ldots \ldots \ldots \ldots \ldots \ldots \ldots \ldots \ldots .20$

Variety of Color.................. 9

Anatomy of $\ldots \ldots \ldots \ldots \ldots \ldots \ldots \ldots \ldots \ldots \ldots \ldots \ldots \ldots \ldots \ldots$

Grayling-Description of $\ldots \ldots \ldots \ldots \ldots \ldots$

Rainbow-Description of $\ldots \ldots \ldots \ldots \ldots \ldots \ldots \ldots \ldots$

Von Behr-Description of ............... 20

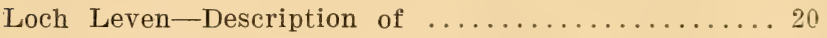

Rocky Mountain-Description of .............20

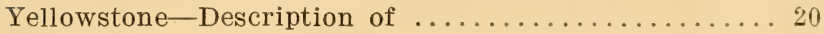

Steelhead-Description of $\ldots \ldots \ldots \ldots \ldots \ldots \ldots \ldots \ldots \ldots \ldots \ldots$

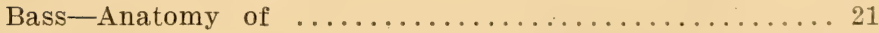

Large Mouth ....................... 22

Small Mouth .....................22

Crappie-Description of ...............2

Crappie-Fly Casting for............... 35

Strawberry-Description of $\ldots \ldots \ldots \ldots \ldots \ldots \ldots \ldots \ldots$ 
Rock-Description of $\ldots \ldots \ldots \ldots \ldots \ldots \ldots \ldots \ldots \ldots \ldots \ldots$

White-Description of $\ldots \ldots \ldots \ldots \ldots \ldots \ldots \ldots \ldots$

Warmouth-Description of $\ldots \ldots \ldots \ldots \ldots \ldots \ldots$

Common Names of $\ldots \ldots \ldots \ldots \ldots \ldots \ldots \ldots \ldots \ldots \ldots$

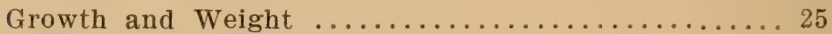

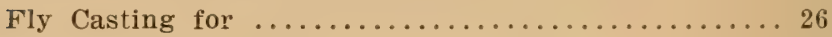

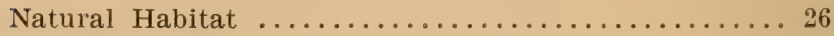

Sunfishes-Description of $\ldots \ldots \ldots \ldots \ldots \ldots \ldots \ldots \ldots \ldots \ldots$

Pickerel-Description of $\ldots \ldots \ldots \ldots \ldots \ldots \ldots \ldots \ldots \ldots \ldots$

Muscallonge-Description of $\ldots \ldots \ldots \ldots \ldots \ldots \ldots \ldots \ldots \ldots \ldots$

Unspotted-Description of $\ldots \ldots \ldots \ldots \ldots \ldots \ldots \ldots 4$

Fishing for $\ldots \ldots \ldots \ldots \ldots \ldots \ldots \ldots \ldots \ldots \ldots \ldots \ldots \ldots \ldots \ldots \ldots, 42$

Tackle Required ...................... 43

Perch-Yellow or Ringed .................... 45

Pike Perch (Wall Eyed Pike)............... 45

Sand Pike, or Jack Salmon................ 45

Carp-Scaled or Asiatic .................... 46

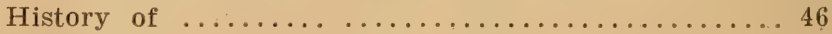

Mirror or King ..................... 47

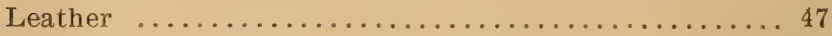

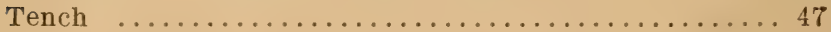

Drum (Fresh Water).................... 51

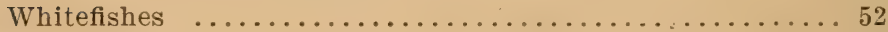

Mooneye-Description of $\ldots \ldots \ldots \ldots \ldots \ldots \ldots \ldots$

Lake Herring-Description of ............. 52

Tullibee ........................... 52

Catfishes-Channel-Description of $\ldots \ldots \ldots \ldots \ldots \ldots \ldots 60$

How to Catch Them ...................... 0

Bullhead or Horned Pout .................. 64

Redhorse ............................6 64

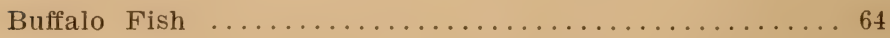

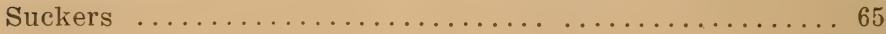




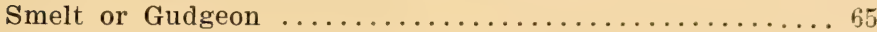

Sheephead .............................66 66

Roach or Golden Shiner $\ldots \ldots \ldots \ldots \ldots \ldots \ldots \ldots \ldots 6$

Chub or Fall Fish .......................66 66

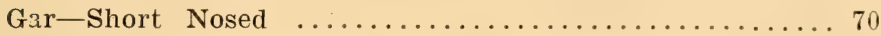

Sturgeon-Short Nosed .....................71-74

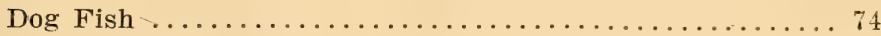

Eel-American $\ldots \ldots \ldots \ldots \ldots \ldots \ldots \ldots \ldots \ldots \ldots \ldots \ldots \ldots$

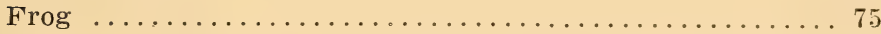

Clam-Fresh Water $\ldots \ldots \ldots \ldots \ldots \ldots \ldots \ldots \ldots \ldots \ldots$

Enemies of Fish......................... 77

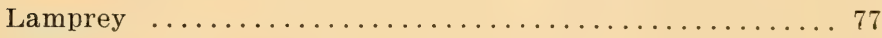

Fish-How to Catch $\ldots \ldots \ldots \ldots \ldots \ldots \ldots \ldots \ldots \ldots \ldots$

Bait for Different Fish . . . . . . . . . . . . . . . 79

Bait and Fly Casting ......................... 79

Tackle for Various Fish $\ldots \ldots \ldots \ldots \ldots \ldots \ldots \ldots \ldots \ldots$

Flies Best Adapted ........................... 79

Fish-Secrets of Catching $\ldots \ldots \ldots \ldots \ldots \ldots \ldots \ldots$

Minnows-How to Catch ..................... 81

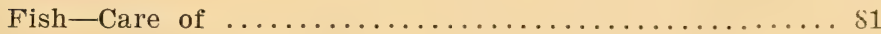

Tackle-Care of $\ldots \ldots \ldots \ldots \ldots \ldots \ldots \ldots \ldots \ldots \ldots \ldots \ldots \ldots \ldots \ldots, 2$

Camp Hints ............................. 84

To Wash Flannels .................... 84

Testing Freshness of Meat ............... 84

To Prepare Fish ....................... 84

Jerked Meat ....................... 84

To Keep Water Cool ........................ S4

Use of Compass $\ldots \ldots \ldots \ldots \ldots \ldots \ldots \ldots \ldots . \ldots 4$

Water Telescope ........................ 55

Sun Glass or Flint Lighter ............... $\$ 5$

Electric Lighter ....................... 85

Pistol or Rifle ...................... 86 
Axe and Knife ......................... 86

Tenting Outfits .................... 86

Camp Location ...................... 86

Lost in the Woods ...................... 86

Blazing the Trail $\ldots \ldots \ldots \ldots \ldots \ldots \ldots \ldots \ldots \ldots$

Camp Fire-Building of $\ldots \ldots \ldots \ldots \ldots \ldots \ldots \ldots$

Camp Supplies for Cooking $\ldots \ldots \ldots \ldots \ldots \ldots \ldots 88$

Camp Rations ........................ 89

How to Cook Fish .......................... 89

Planked Fish ......................... 89

Smoked Fish ........................ 90

Camp Cooking Recipes $\ldots \ldots \ldots \ldots \ldots \ldots \ldots \ldots \ldots . . .61$

Medicines for Emergency .................... 92

Boat for Fishing $\ldots \ldots \ldots \ldots \ldots \ldots \ldots \ldots \ldots \ldots \ldots \ldots \ldots$

Flies-Kind to Use $\ldots \ldots \ldots \ldots \ldots \ldots \ldots \ldots \ldots \ldots \ldots$

Minnows-How to Hook ...................... 95

Fish Laws-Western States ................. 96-97.

Game Laws-Western States ................... $98-99$

Fishes of the West-Species of ............. 100-104 


\section{INDEX TO ILLUSTRATIONS.}

Page.

Brook Trout-Speckled $\ldots \ldots \ldots \ldots \ldots \ldots \ldots \ldots \ldots \ldots, 8$

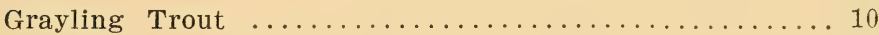

Rainbow Trout ...........................11

Von Behr Trout-German Brown............... 14

Loch Leven Trout ..................... 15

Rocky Mountain Trout .................. 16

Yellowstone Trout $\ldots \ldots \ldots \ldots \ldots \ldots \ldots \ldots \ldots \ldots \ldots \ldots \ldots \ldots$

Lake Trout ............................... 18

Steelhead Trout .......................... 19

Bass-Anatomy of $\ldots \ldots \ldots \ldots \ldots \ldots \ldots \ldots \ldots \ldots \ldots \ldots \ldots \ldots \ldots \ldots$

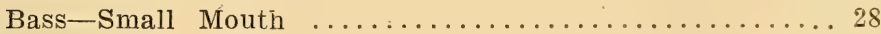

Bass-Large Mouth ....................... 29

Bass-Rock .......................... 30

Bass-White ............................ 31

Bass-Warmouth ....................... 32

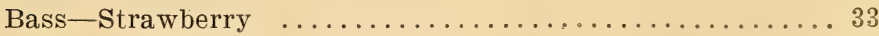

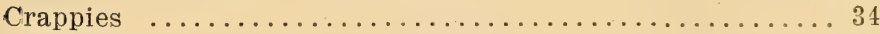

Sunfish (Blue Eared) ........................... 36

Mooneye--Toothed Herring ....................... 37

Pickerel (English Pike) .................... 39

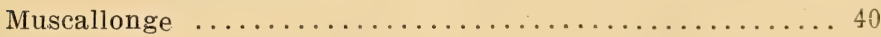

Muscallonge-Unspotted .................... 41

Perch-Yellow ........................... 43

Perch (Pike) -Wall Eyed Pike ................. 44

Carp-Scaled or Asiatic ..................... 48

Carp-Mirror or King . ..................... 49 
Carp-Leather ......................... 50

Drum Fish-Fresh Water .................. 51

White Fishes-Lake Herring $\ldots \ldots \ldots \ldots \ldots \ldots \ldots \ldots \ldots \ldots$

Whitefish-Mountain ...................... 55

Whitefish-Rocky Mountain $\ldots \ldots \ldots \ldots \ldots \ldots \ldots \ldots \ldots \ldots \ldots$

Whitefish-Williamson's $\ldots \ldots \ldots \ldots \ldots \ldots \ldots \ldots \ldots \ldots \ldots$

Tullibee ............................. 58

Catfish-Channel ......................... 59

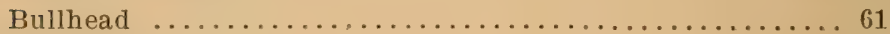

Red Horse ............................. 62

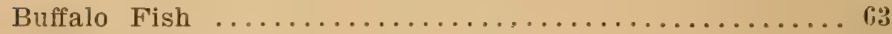

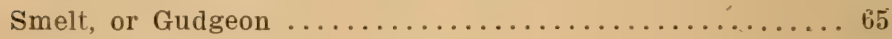

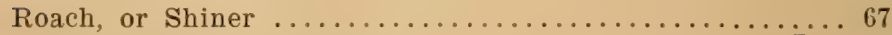

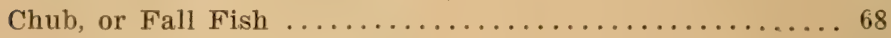

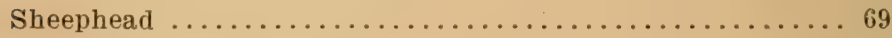

Gar-Short Nosed.$\ldots \ldots \ldots \ldots \ldots \ldots \ldots \ldots \ldots \ldots \ldots \ldots \ldots \ldots$

Sturgeon-Short Nosed $\ldots \ldots \ldots \ldots \ldots \ldots \ldots \ldots \ldots \ldots \ldots \ldots$

Dog Fish ..............................

Eel-American $\ldots \ldots \ldots \ldots \ldots \ldots \ldots \ldots \ldots \ldots \ldots \ldots \ldots \ldots \ldots \ldots$

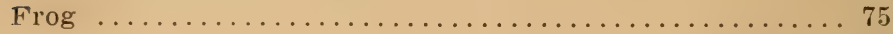

Lamprey $\ldots \ldots \ldots \ldots \ldots \ldots \ldots \ldots \ldots \ldots \ldots \ldots \ldots \ldots \ldots \ldots$

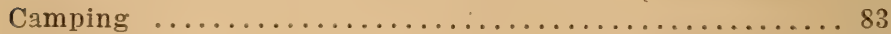

Telescope-Water $\ldots \ldots \ldots \ldots \ldots \ldots \ldots \ldots \ldots \ldots \ldots \ldots \ldots$

Boat-Proper for Fishing $\ldots \ldots \ldots \ldots \ldots \ldots \ldots \ldots \ldots . . \ldots 3$

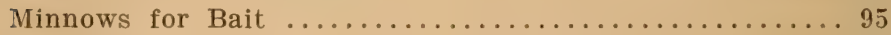







"

$\%$

- Mat

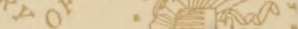

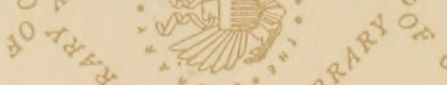

05

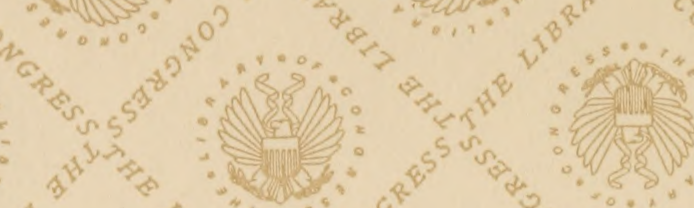

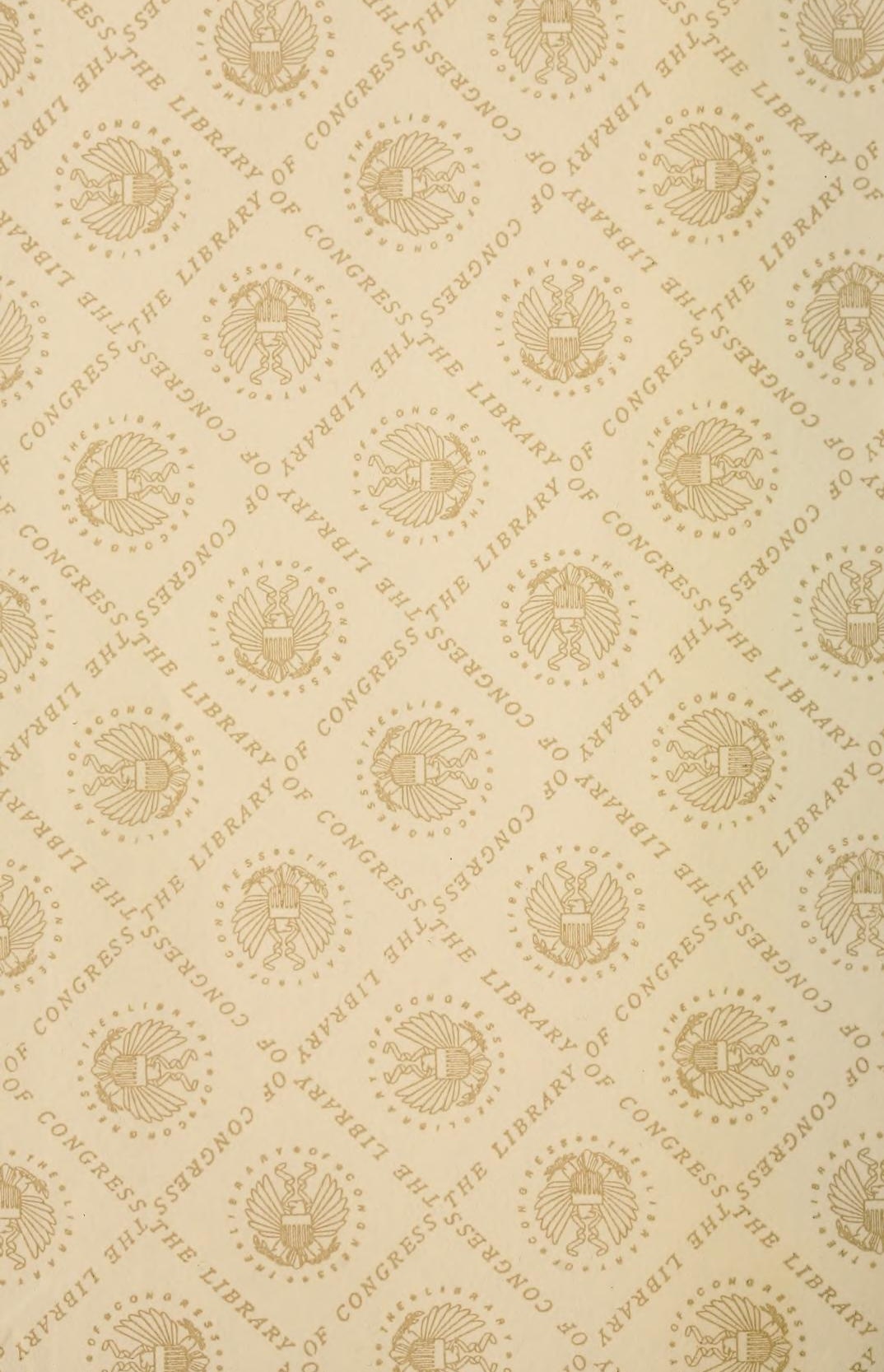




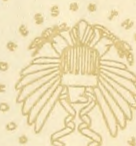

70

\section{APR 78}


LIBRARY OF CONGRESS

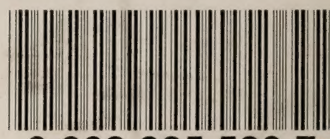

00028855837 